\title{
Granitic dimensional stones in Uruguay: evaluation and assessment of potential resources
}

\author{
Manuela Morales Demarco • Pedro Oyhantçabal • \\ Karl-Jochen Stein $\cdot$ Siegfried Siegesmund
}

Received: 23 April 2012/ Accepted: 12 September 2012/Published online: 10 November 2012

(C) The Author(s) 2012. This article is published with open access at Springerlink.com

\begin{abstract}
In Uruguay commercial granite varieties comprise mafic rocks, granitoids, and syenitoids. There is a long tradition in Uruguay, as well as worldwide, of using dimensional stones in architecture and art, specially granitic ones. Some of the present applications of these dimensional stones are as façade cladding, countertops, and outdoor and indoor floor slabs. The color spectrum of the Uruguayan granitic dimensional stones varies from black to light gray, covering a wide variety of red and pink and minor greenish-gray. The décor of these granitic dimensional stones is mainly determined by their fabric, fundamentally the grain size and the color distribution between the different minerals that compose the rocks. In the present research the most important commercial granites were sampled to analyze their petrography and petrophysical properties. A detailed structural analysis has been performed in several deposits, as well as the application of the software 3D Block Expert for modeling the possible raw block size distribution. Other factors controlling the mining viability of the deposits were also studied (e.g., homogeneity/heterogeneity of color and décor) and the possible reserves were calculated.
\end{abstract}

M. Morales Demarco $(\bowtie) \cdot$ S. Siegesmund

Geoscience Center of the Georg-August University Göttingen, Goldschmidtstrasse 7, 37077 Göttingen, Germany

e-mail: manugea@gmail.com

P. Oyhantçabal

Departamento de Geología, Facultad de Ciencias, Universidad de la República, Iguá 4225, C.P. 11400 Montevideo, Uruguay

K.-J. Stein

Natursteininformationsbüro, Am Schulzensee 3, OT Waldsee, 17258 Feldberger Seenlandschaft, Germany
Keywords Granitic dimensional stones - Petrophysical properties · Petrography · Deposit characterization . Uruguay

\section{Introduction}

Terms and standards

Granitic dimensional stones are widely used in architecture. Some examples include paving tiles, monuments, interior and exterior wall cladding (Montani 2008) (Figs. 1, 2). Its share of the market of dimensional stones has doubled in the period between 1995 and 2007 (Montani 2008). Due to their durability, granite represents one of the preferred natural materials when deterioration risk is present.

Commercially, the term granite is used for dimensional stones consisting of all the hard rocks, even when their lithology strongly differs from that of true granite. In the Earth Sciences, the use is stricter and the name granite only applies to a plutonic rock containing quartz, alkali feldspar, and plagioclase. These rocks plot in a specific field defined by the QAPF classification triangle (Streckeisen 1976).

Granitoid is a superordinate category designating a plutonic rock that has between 20 and 60 percent quartz in the QAPF classification (Streckeisen 1976; Le Maitre et al. 2002; Allaby and Allaby 1990; Jackson 1997). It includes the alkali feldspar granites, granites sensu stricto, granodiorites, and tonalites. Syenitoid is a term used for plutonic rocks with a quartz content ranging between 0 and $20 \%$ and a feldspar ratio (alkali feldspar/plagioclase + alkali feldspar) between 35 and $100 \%$ (Streckeisen 1976; Le Maitre et al. 2002; Allaby and Allaby 1990; Jackson 1997). Gabbroids include all the plutonic rocks showing a feldspar 

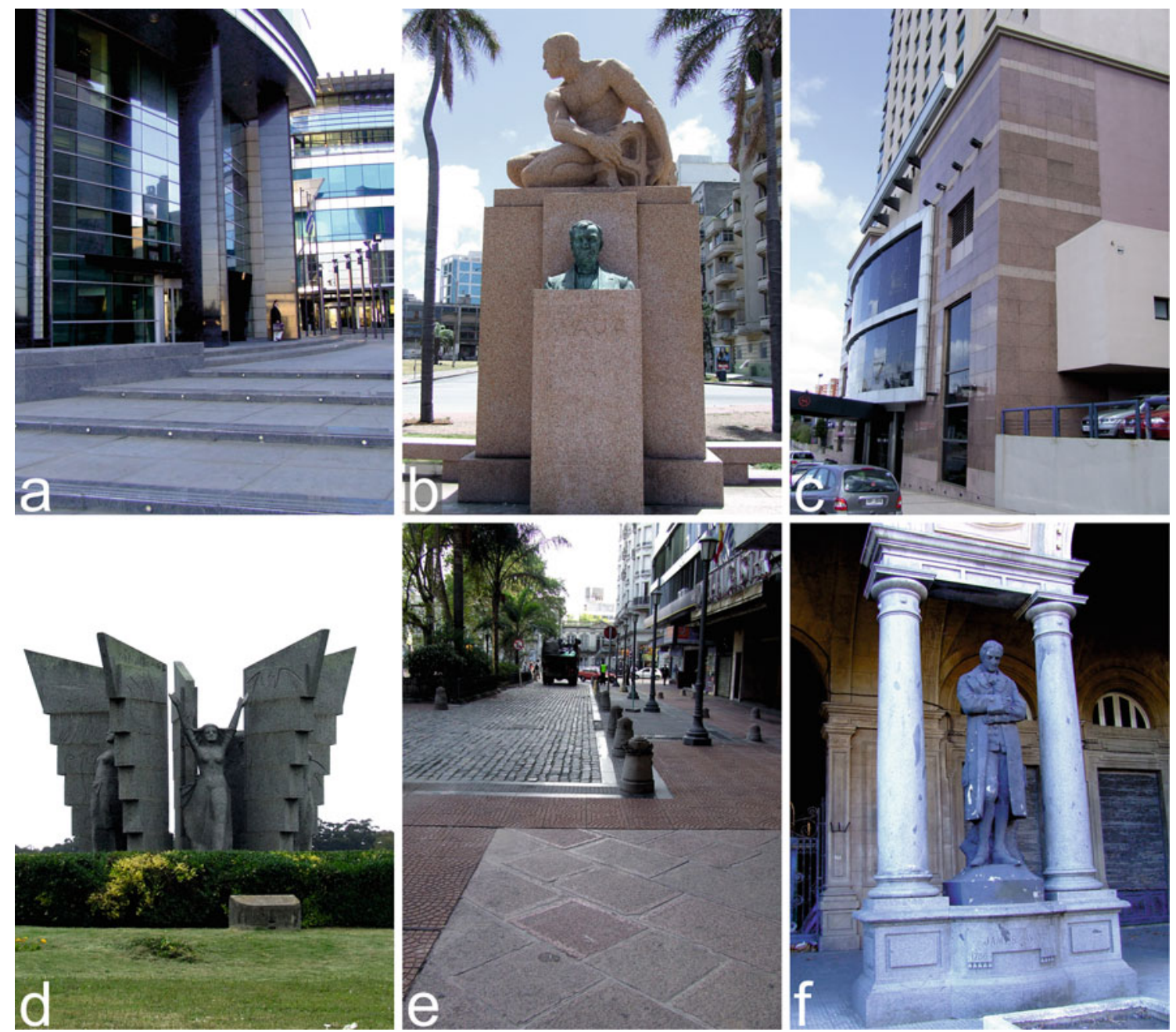

Fig. 1 Uses of Uruguayan commercial granites in the city of Montevideo; a outdoor façade cladding using Moderate Black Dolerite and flooring slabs using Cufré Granite in the Antel Tower; b outdoor sculpture (Vizconde de Mauá) using La Paz Granite; c outdoor façade cladding using polished and unpolished slabs of
Violeta Imperial Syenite; $\mathbf{d}$ outdoor sculpture using Moskart Granite; e different sorts of outdoor flooring slabs using granite; and $\mathbf{f}$ outdoor socle and columns using Isla Mala Tonalite in the Central Train Station (Estación Central AFE)

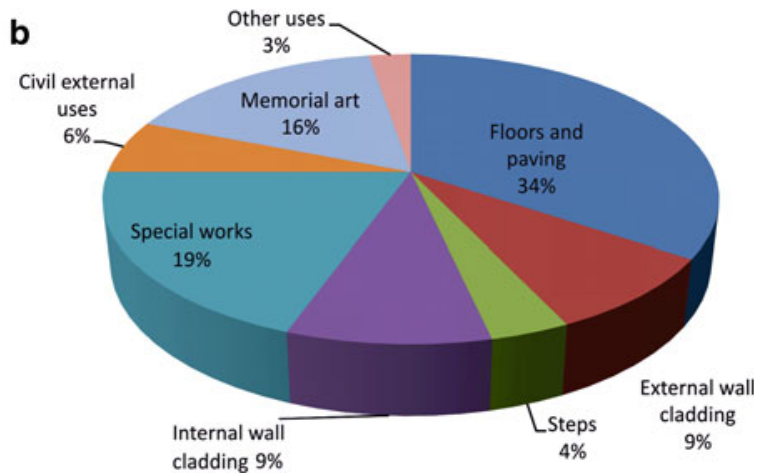

Fig. 2 Global main uses of dimensional stones (in percentage) after Montani (2008) a global uses in 1995 (total finished production: 25 million tons); and b global uses in 2007 (61 million tons)

ratio between 0 and $35 \%$ and quartz contents between 0 and $20 \%$ (Streckeisen 1976; Le Maitre et al. 2002; Allaby and Allaby 1990; Jackson 1997). Mafic rock is a term that includes gabbroids but also other igneous rocks (e.g., basalt) composed chiefly by mafic minerals (Jackson 1997). 
At the beginning of the 21 st century, the European countries decided that dimensional rocks must be correctly named according to the petrological description and the standards of international geological terminology (e.g., DIN EN 12407, 2007; DIN EN 12670, 2000; DIN EN 12670, 2001). Outside Europe the American standards are normally used (e.g., ASTM C119 2011). These standards allow the naming of granite as granular igneous rocks, which includes granitoids, syenitoids, and mafic rocks (gabbros, dolerites), but also some granular metamorphic rocks such as gneisses and schists (Quick 2002).

In Uruguay, what is commercially known as "granite" includes a wide variety of lithologies such as granitoids (granodiorite, tonalite, granite s.s.), syenitoids (quartz syenite, alkali feldspar syenite and quartz alkali feldspar syenite), and mafic rocks (gabbro-norite and dolerite) (Table 1). The colored commercial granites include syenitoids and granites s.s., whereas the gray granites comprise granites s.s., granodiorites and tonalites. The rocks that are commercially known as black granites are basically dolerites and gabbro-norites.

\section{Production}

The mining of dimensional stones in Uruguay began during the first settlements with the construction of fortifications and citadels between the end of the 17 th and the beginning of the 18th centuries. Examples are the fortress of Santa Teresa, built from the porphyritic facies of the Santa Teresa Granite and the citadels of Colonia del Sacramento and Montevideo constructed from local granitic and metamorphic rocks. Since the beginning of the 20th century until today, commercial granites have been used for a wide variety of architectural and artistic purposes.

The dimensional stone sector had a very important productive phase at the beginning of the 20th century. Syenitoids of the Pan de Azúcar-Piriápolis area and granites of La Paz provided material for the construction of the most important cities of the region, especially for Montevideo and the neighboring city of Buenos Aires.

The international trend of using commercial granites mainly for decorative purposes and not only for structural ones is a practice used by the architects and construction companies in Uruguay. Commercial granite is used in Uruguay for façade cladding, as paving tiles, for interior floor and wall cladding, countertops, stairs, columns, sculptures, monuments, and precision tables, among other applications (Fig. 1).

The dimensional stone market is particularly sensitive to fashion trends and economic constrains. Beginning in the year 2000 the economic crisis in South America led to a severe decline in the construction industry, and thus, in the dimensional stone production.
The world production of all types of dimensional stone in 2007 was 103 million tons (Montani 2008). The leading productive countries in that year were China, India, Turkey, Italy, and Spain, which together produced almost $60 \%$ of the dimensional stone (Montani 2008). In 2007 Latin America produced 6.5 million tons, with Brazil being the main producing country with 5.75 million tons, followed by Argentina with 0.35 million (Montani 2008). Uruguayan production in the same year was of 7,048 tons (DI.NA.MI.GE. 2008), just $0.11 \%$ of the total Latin American production.

The most important countries in the granitic dimensional stone sector are China, India, Spain, and Portugal as illustrated in Fig. 3, where the dimensional and granitic stone production in million tons is shown. The importance of granitic rocks in this production is visible in Fig. 4, where the total dimensional stone production is divided into three main stone varieties: commercial granites, marble and travertine, and slate and others. Worldwide production of commercial granites has almost quadruplicated in 82 years (Montani 2008).

The production of dimensional stone in Uruguay today is mainly represented by granite, slates, and sandstone with a marginal proportion of marble (Fig. 5). The most important variety in the commercial production of granite is the black granite (dolerite), mainly the Moderate Black variety. In order to gain a better idea of the importance of each commercial variety, the production (in $\mathrm{m}^{3}$ ) was calculated using the original data in tons from DI.NA.MI.GE. (2008) for the year 2007 and the density values obtained in this research. Dolerites showed a production of $1,810 \mathrm{~m}^{3}$, representing $81 \%$ of the commercial granite production, gray granites represent $10 \%$, greenish-gray granite $5 \%$ (Soca or Moskart), and pink granite $4 \%$ (La Paz or Caramel Pink).

The economic geological evaluation of dimensional stone deposits essentially relies on two factors (e.g., Peschel 1977; Singewald 1992): (i) the presumable occurrence of raw blocks (referring to the proportion of raw blocks suitable for industrial processing) and (ii) the petrophysical properties (tested according to EN norms), which provide information about the rock behavior under the influence of deterioration forces.

The production of raw blocks of adequate décor and size is a major factor in the economic evaluation of a deposit. An optimal block size is required for economical processing using modern cutting techniques (e.g., a minimum block size of $2.5 \times 1.3 \times 1 \mathrm{~m}$ is necessary when using the gang saw blade). This optimal size must also take into account the associated processing losses (e.g., oddments). This is essentially controlled by the structural elements (e.g., the spatial distribution of joint systems and their frequency) and the homogeneity of the rock deposit. 
Table 1 List of commercial granites from Uruguay (Data source Bossi and Navarro 2000; DI.NA.MI.GE. 2011; Comunità Economica Europea, no date; author's database)

\begin{tabular}{|c|c|c|c|c|c|}
\hline Rock & Id & Commercial type & Commercial name & Locality & Department \\
\hline Dolerite & U8 & Black granite & Sacramento (Comercio Exterior S.A.) & $\mathrm{A}^{\circ}$ Pichinango & Colonia \\
\hline Dolerite & U11A & Black granite & Absolute (Black Stone S.A.) & $\mathrm{A}^{\circ}$ de la Quinta & San José \\
\hline Dolerite & U110 & Black granite & Moderate or Oriental (Black Stone S.A.) & $\mathrm{A}^{\circ}$ de la Quinta & San José \\
\hline Dolerite & U66 & Black granite & Oriental (Pimafox) & $\mathrm{A}^{\circ}$ Polonia & Colonia \\
\hline Gabbro-norite & U87 & Black Granite & Mahoma Black & Mal Abrigo & San José \\
\hline Basalt & U49 & Black granite & Arapey Black & Arroyo Valentín Chico & Salto \\
\hline Granite & $\mathrm{U} 2$ & Gray granite & Maldonado Gray & Maldonado & Maldonado \\
\hline Granodiorite & U4 & Gray granite & Chamangá Gray & Arroyo Chamangá & Flores \\
\hline Granite & U53 & Gray granite & Cuchilla del Perdido Gray Blue & Chuchilla del Perdido & Soriano \\
\hline Granite & U70 & Gray granite & Cerro Áspero or Gray Rocha & Arroyo Sauce de Rocha & Rocha \\
\hline Granite & U73 & Gray granite & Cufré Gray Blue & Cufré & Colonia \\
\hline Granite & U80 & Gray granite & Cerro de Carmelo Gray & El Cerro. Carmelo & Colonia \\
\hline Granite & U81 & Gray granite & Ismael Cortinas Gray & Ismael Cortinas & Flores \\
\hline Granite & U82 & Gray granite & Loyner Gray & & Flores \\
\hline Granite & U83 & Gray granite & Goñi Gray & Goñi & Florida \\
\hline Granite & U85 & Gray granite & Iguazú or Garzón Gray & Garzón & Rocha \\
\hline Granite & U89 & Gray granite & Losten Gray & & Soriano \\
\hline Granite & U90 & Gray granite & Dionisio Gray & Cuchilla de Dionisio & Treinta y Tres \\
\hline Granite & U93 & Gray granite & Santa Teresa Gray & Santa Teresa & Rocha \\
\hline Tonalite & U94 & Gray granite & Isla Mala Gray & 25 de Agosto & Florida \\
\hline Granite & U95 & Gray granite & Northern Garzón Gray & Garzón & Maldonado \\
\hline Granite & $\mathrm{U} 7$ & Dark green granite & Labradorita Oriental or Moskart & Soca & Canelones \\
\hline Granite & U74 & Red granite & Caramel Pink or La Paz & La Paz & Canelones \\
\hline Granite & U75 & Red granite & Asperezas & $\mathrm{A}^{\circ}$ Asperezas $-\mathrm{A}^{\circ}$ Malo & Cerro Largo \\
\hline Granite & U76 & Red granite & Guazunambí, Montevideo or Iguazú & Arbolito & Cerro Largo \\
\hline Granite & U77 & Red granite & Luján or Santa Clara & Santa Clara del Olimar & Cerro Largo \\
\hline Granite & U84 & Red granite & Sarah Pink & & Lavalleja \\
\hline Granite & U88 & Red granite & Mahoma Red & Mal Abrigo & San José \\
\hline $\begin{array}{l}\text { Quartz alkali feldspar } \\
\text { syenite }\end{array}$ & U15 & Red granite & Salmon Red or Guazubirá & Sierra de Ánimas & Maldonado \\
\hline Alkali feldspar syenite & U46 & Red granite & Artigas Pearl or Artiqas & Piriápolis & Maldonado \\
\hline Quartz-syenite & U47 & Red granite & Violeta Imperial & Sierra de Ánimas & Maldonado \\
\hline $\begin{array}{l}\text { Quartz alkali feldspar } \\
\text { syenite }\end{array}$ & U92 & Gray granite & Pan de Azúcar White & Piriápolis & Maldonado \\
\hline
\end{tabular}

Currently, no models exist for sustainable mining of these types of deposits, which reduces the waste material generated when producing an optimal block size.

Scope of the article and state of art

Uruguay has a wide variety of dimensional stones in terms of color and décor; however, petrophysical properties and deposits has not been sufficiently studied. The present study aims to contribute to the economic geological development of the granitic dimensional stones of Uruguay with respect to further exploration, evaluation, mining, and marketing.
Another important goal of the present study is to evaluate the petrophysical properties of the different granitic dimensional stones of Uruguay to determine the best potential uses of these rocks. Furthermore, the deposits are characterized according to color and décor, so that the distribution of commercially interesting stones can be determined as well as the factors controlling the deposits. These factors are the volume of the deposit, the lithological aspects, and the structural elements present. In order to provide a steady product for the market the volume of material available is important. However, the waste material is also of secondary economic value in the operation of dimensional stone deposit. Structural elements control the 


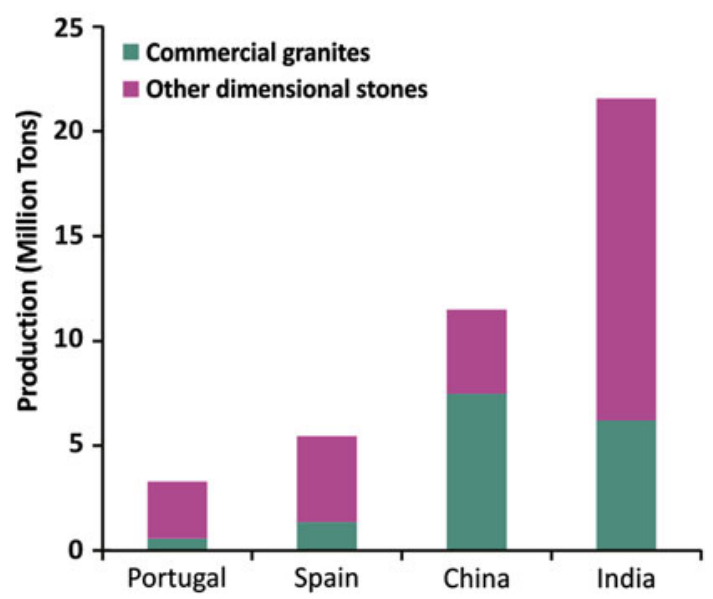

Fig. 3 Examples of dimensional stone production in million tons for the year 2001 (Sources Spain: Federación Española de la Piedra Natural 2008; India: Centre for Development of Stones-Jaipur 2011; Portugal: Direcção Geral de Energia e Geologia (DGEG) and Divisão de Estatística 2011; China: Jorge Quiroz C Consultores Asociados 2006)

deposit by the joint system present, whereby their distribution determines the shape and volume of the blocks being mined. Lithological aspects define the suitability of a granitic rock for use as a dimensional stone, since it controls the color and décor. The mineral composition and fabric are important for the characterization of a dimensional stone with respect to the petrophysical properties of the rock, as well as its resistance to weathering.

Similar investigations on granitic dimensional stones in Thailand were carried out by Hoffmann (2006), Hoffmann and Siegesmund (2007), in Argentina by Mosch et al. (2007) and in Uruguay by Morales Pérez and Muzio (2005) and Oyhantçabal et al. (2007). Some examples of detailed research in exotic granitic rocks include an investigation on the larvikites of Norway (Heldal et al. 2008), on dolerites from Uruguay (Bossi and Campal 1991; Morales Demarco et al. 2011), and on a granitic batholith in São Paulo, Brazil (Artur et al. 2001).

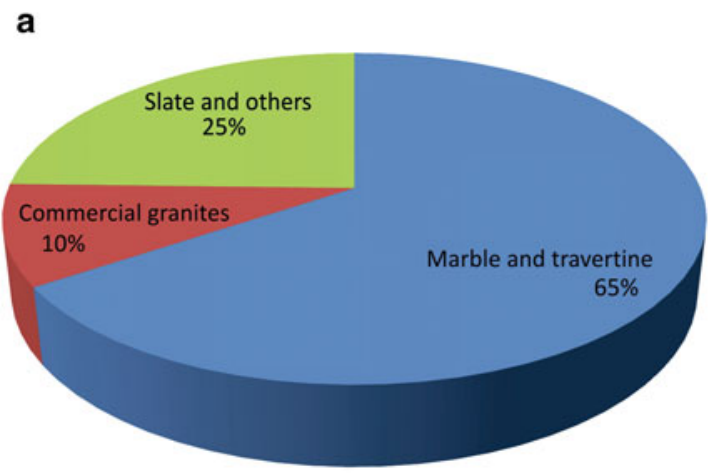

\section{Geological setting}

Uruguayan geology is characterized by an igneous-metamorphic basement and several basins distributed in different regions of the country (Fig. 6). The crystalline basement was originally divided into two domains by Ferrando and Fernández (1971), the western domains belonging to the Transamazonian Cycle (Paleoproteozoic) and the eastern one to the Brasiliano Cycle (Neoproterozoic).

Today the western domain is known as Rio de la Plata Craton (Almeida et al. 1973; Bossi and Ferrando 2001; Oyhantçabal et al. 2010), which extends westwards into Argentina. The eastern domain is divided into the Nico Pérez and Punta del Este Terranes (Bossi and Ferrando 2001; Oyhantçabal et al. 2010). A mobile belt known as the Dom Feliciano Belt is located between these two terranes (Fragoso César 1980; Oyhantçabal et al. 2009, 2010). The boundaries between these tectono-stratigraphic units are from west to east: the Sarandí del Yí Shear Zone (SYSZ) and Sierra Ballena Shear Zone (SBSZ).

Since the Neoproterozoic the Uruguayan continental area was quite stable, but was interrupted in the Lower Cretaceous by the opening of the South Atlantic Ocean. In this major event, rift basins with associated bimodal magmatism opened and flood basalts were deposited over a wide area of South America, known as the Paraná Basin, which also includes northwestern Uruguay.

\section{Regionalization of commercial granite deposits}

The commercial granite deposits found in Uruguay occur in three tectono-stratigraphic units: the Dom Feliciano Belt (DFB), the Río de la Plata Craton (RPC), and the Punta del Este Terrane (PET) (Fig. 6). The main tectonic events did not negatively affect the petrophysical properties and the possibility of mining these intrusive rocks. Exceptions can be found locally in some deposits, where a brittle regime

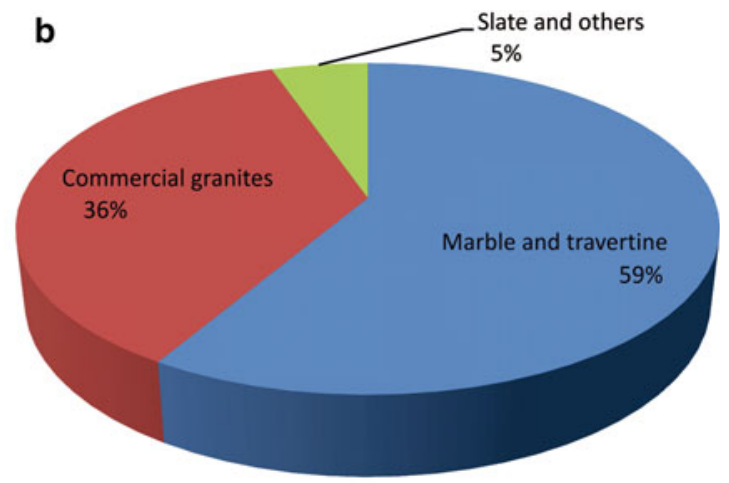

Fig. 4 World dimensional stone production classified by rock type (in percentage) after Montani (2008) a production in 1926 (total production is 1.79 million tons); and $\mathbf{b}$ production in 2007 (total production is 103.5 million tons) 


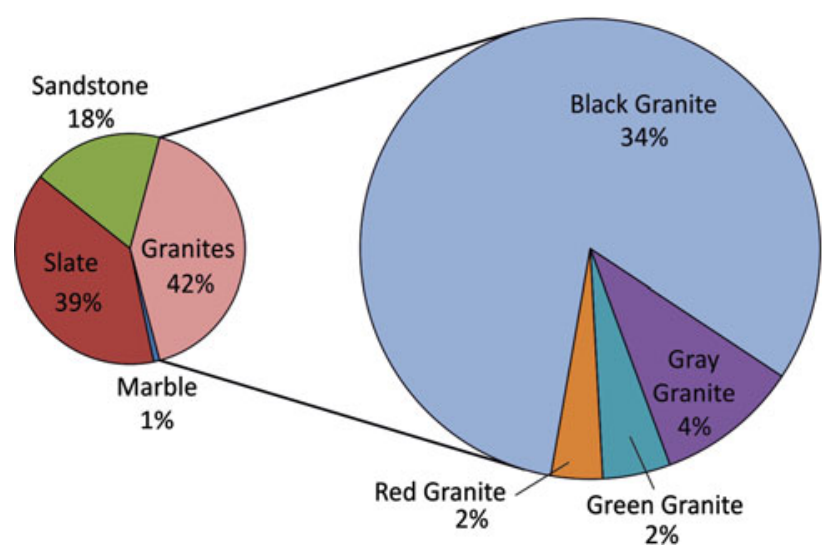

Fig. 5 Production of dimensional stone in Uruguay in 2007 (in percentage) (total production is $5,322 \mathrm{~m}^{3}$ ) (Data source DI.NA.MI.GE. 2007)

developed cataclastic zones where no mining can take place.

Most of the dimensional stone deposits in Uruguay are located in the DFB and many of them are granitic rocks. Syenitoid deposits, for example, are located in the Sierra de Ánimas Complex (Coronel et al. 1987; Bossi and Navarro 2001; Morales Pérez 2004; Oyhantçabal et al. 2007). The commercial varieties are characterized by their light red, pink, violet, and gray colors. The commercial varieties Artigas Pearl (Fig. 7e) and Pan de Azúcar White are located in the southernmost portion of this complex (See Fig. 6), whereas the Salmon Red (Fig. 7g) and the Violeta Imperial (Fig. 7h) are in the central part.

In the central part of the DFB (Preciozzi et al. 1985; Bossi and Navarro 2000; Bossi and Ferrando 2001; Morales Pérez 2004) deposits of red granites are located, e.g., the Luján or Santa Clara Granite. Further to the north in the DFB a red granite deposit is located: the Guazunambí Granite (See Fig. 6) (Preciozzi et al. 1985; Bossi and Navarro 2000; Bossi and Ferrando 2001; Morales Pérez 2004). The rock shows a gentle foliation since this region experienced a progressive deformation toward the Sierra Ballena Shear Zone (SBSZ). The deformed gray granite deposits are associated with the SBSZ. Maldonado Gray is one of these granites, which shows the most developed features of synmagmatic deformation of all the commercial granites analyzed, having a very well-developed foliation and mineral lineation.

In the RPC, a dolerite dike swarm crops out in an area of 20,000 km ${ }^{2}$ (Bossi and Campal 1991; Morales Demarco et al. 2011). The mined dolerite is commercialized as high quality black granite consisting of two varieties, based on the intensity of their black color: Absolute Black and Moderate Black (Fig. 7a, b; Coronel et al. 1987; Bossi and Campal 1991; Morales Demarco et al. 2011). Absolute Black is mined from dikes that have a fine-grained zone wide enough to produce marketable blocks. Two other mafic rocks with increasing importance are also located in the Piedra Alta Terrane (PAT): belonging to the Guaycurú Complex (Bossi and Schipilov 2007) is the gabbro-norite known as Mahoma Black and belonging to the Arapey Group is the Arapey Basalt. The Arapey Group is composed of six different lithostratigraphic units (formations), each one interbedded with several lava flows that show variations in the geochemical and mineralogical composition (Bossi and Schipilov 2007).

Since the Paleoproterozoic the Río de la Plata craton remained relatively tectonically stable, with no indication of deformational events or moderate ones. Evidence of high-grade metamorphic overprinting in the intrusions is absent. The lack of these structural elements in this craton makes the extraction of commercial granites possible.

Gray granites, tonalites, and granodiorites are very common in this craton. Some examples of commercial gray granitoids are the Chamangá Gray, Goñi Gray, and the Cuchilla del Perdido Gray Blue granites (Fig. 7c). In the locality of Cufré is found a granite with a moderate foliation determined not only by the biotite (Preciozzi et al. 1985), but also by the alignment of the mafic enclaves: the Cufré Gray Blue (Fig. 7f). In the city of La Paz is located the La Paz Granite (Preciozzi et al. 1985; Oyhantçabal et al. 1990a) (Fig. 7i), whose porphyritic facies is known as the Caramel Pink Granite and together with the Mahoma Red and Moskart Granites (Fig. 7d), they illustrate examples of colored granites s.s. in this unit.

In the PET only gray granite deposits have been mined. Some of them are fine-grained like the Cerro Áspero and Garzón granites (Preciozzi et al. 1985). Moreover, very coarse-grained granites showing oriented alkali feldspar phenocrysts occur (Preciozzi et al. 1985; Muzio and Artur 1999), and these are known as the Santa Teresa Gray Granite.

\section{Lithological inventory}

Previous authors have studied the granitic rocks of Uruguay that are used as dimensional stones by paying special attention to the dolerites, syenitoids, greenish-gray granites, and some of the red and gray granites (Scheer 1964; Caruso 1987; Bossi and Navarro 2000; Morales Pérez 2004; Spoturno et al. 2004a, b, c; Techera et al. 2004a, b, c). The different commercial granites of Uruguay are classified according to their mineralogical and geochemical composition into mafic rocks, granitoids, and syenitoids. In Fig. 8 the modal composition of the commercial granites is plotted using the QAP diagram proposed by Streckeisen (1976). In Fig. 9a the geochemical analyses are plotted in the R1-R2 diagram (De La Roche et al. 1980) and in Fig. 9b in the TAS diagram (Middlemost 1997; Best 2003). 


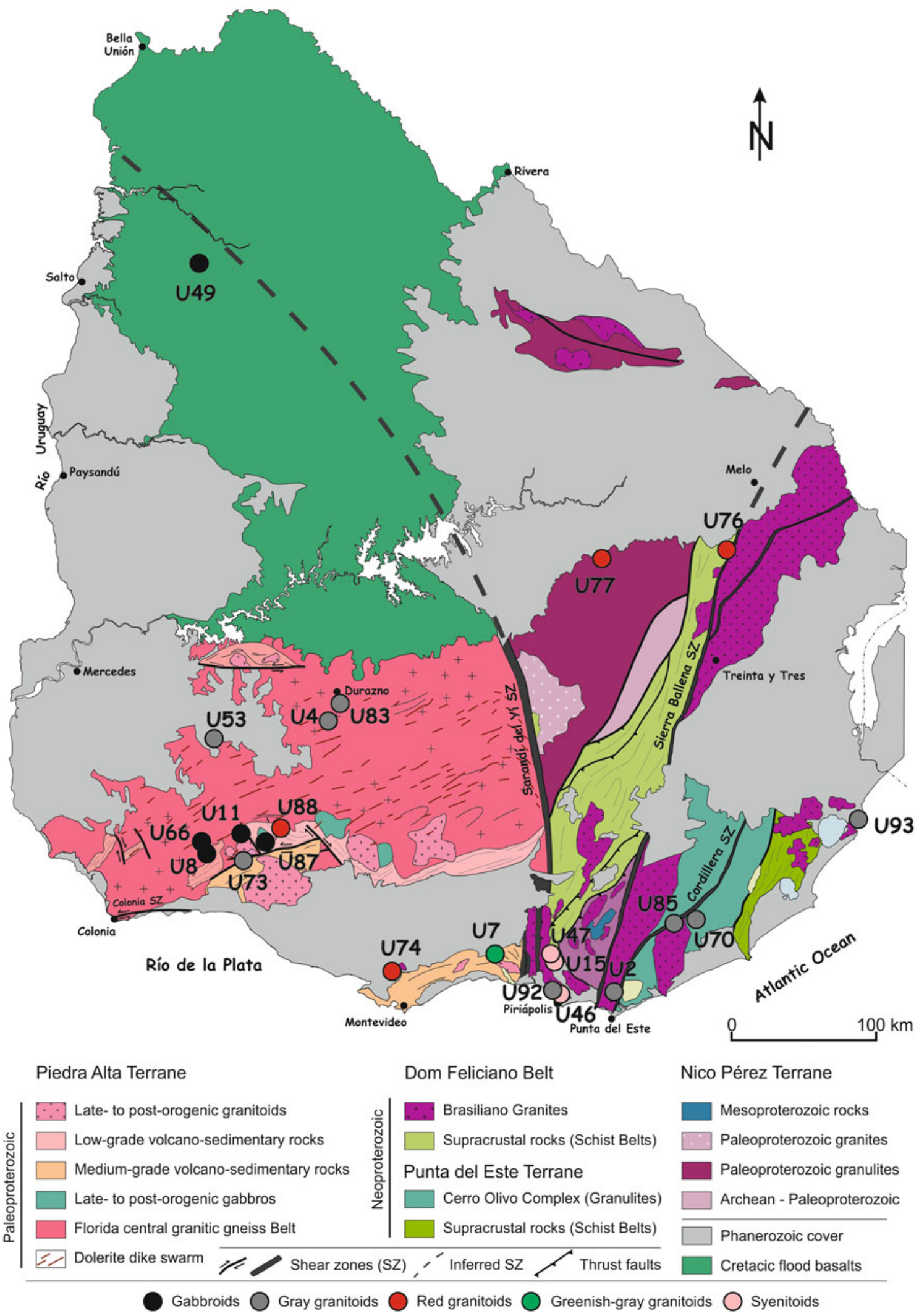

Fig. 6 Geological map of Uruguay with deposit localities (redrawn after Oyhantçabal et al. 2010; Sánchez Bettucci et al. 2010) 



Fig. 7 Polished slabs of Uruguayan commercial granites (slab length $=10 \mathrm{~cm}$ ) a Absolute Black Dolerite; b Moderate Black Dolerite; c Cuchilla del Pérdido Gray Granite; d Moskart Granite;

Tables 2 and 3 shows the geochemical analyses for the commercial granite varieties.

\section{Mafic group}

The rocks belonging to the mafic group are characterized by their black color resulting from their mineralogical composition and grain size. The Uruguayan mafic rocks have $\mathrm{SiO}_{2}$ values between 48.6 (Mahoma Gabbro, Bossi and Schipilov 2007) and 55.43 wt\% (Absolute Black Dolerite), $\mathrm{FeO}_{t}$ values between 8.82 and $14.50 \mathrm{wt} \%, \mathrm{MgO}$ between 3.04 and 7.13, and $\mathrm{CaO}$ between 6.97 to $9.74 \mathrm{wt} \%$. These rocks belong to the basic to intermediate field (Table 2). The mafic rocks in this category all have a tholeitic affinity e Artigas Pearl Syenite; f Cufré Gray Granite; g Salmon Red Syenite; h Violeta Imperial Syenite; and i Caramel Pink Granite

and their intrusion occurred in an extensional regime (Bossi and Campal 1991; Bossi and Schipilov 2007).

The dolerites have been extensively studied by Bossi and Campal (1991) and Morales Demarco et al. (2011). Bossi and Campal (1991) determined two geochemical and petrographic groups. The rocks of Group A are composed of plagioclase and lower amounts of augite, granophyric intergrowth, amphibole, and opaques; and are characterized by high $\mathrm{TiO}_{2}$ contents and an andesitic composition (Bossi and Campal 1991; Morales Demarco et al. 2011). Group B has a low $\mathrm{TiO}_{2}$ content and an andesitic-basalt composition. In both groups the opaques are magnetite, ilmenite, and hematite, although they differ in the total amount (Table 4). 
Fig. 8 QAP diagram of Uruguayan commercial granites (modified after Streckeisen 1976)

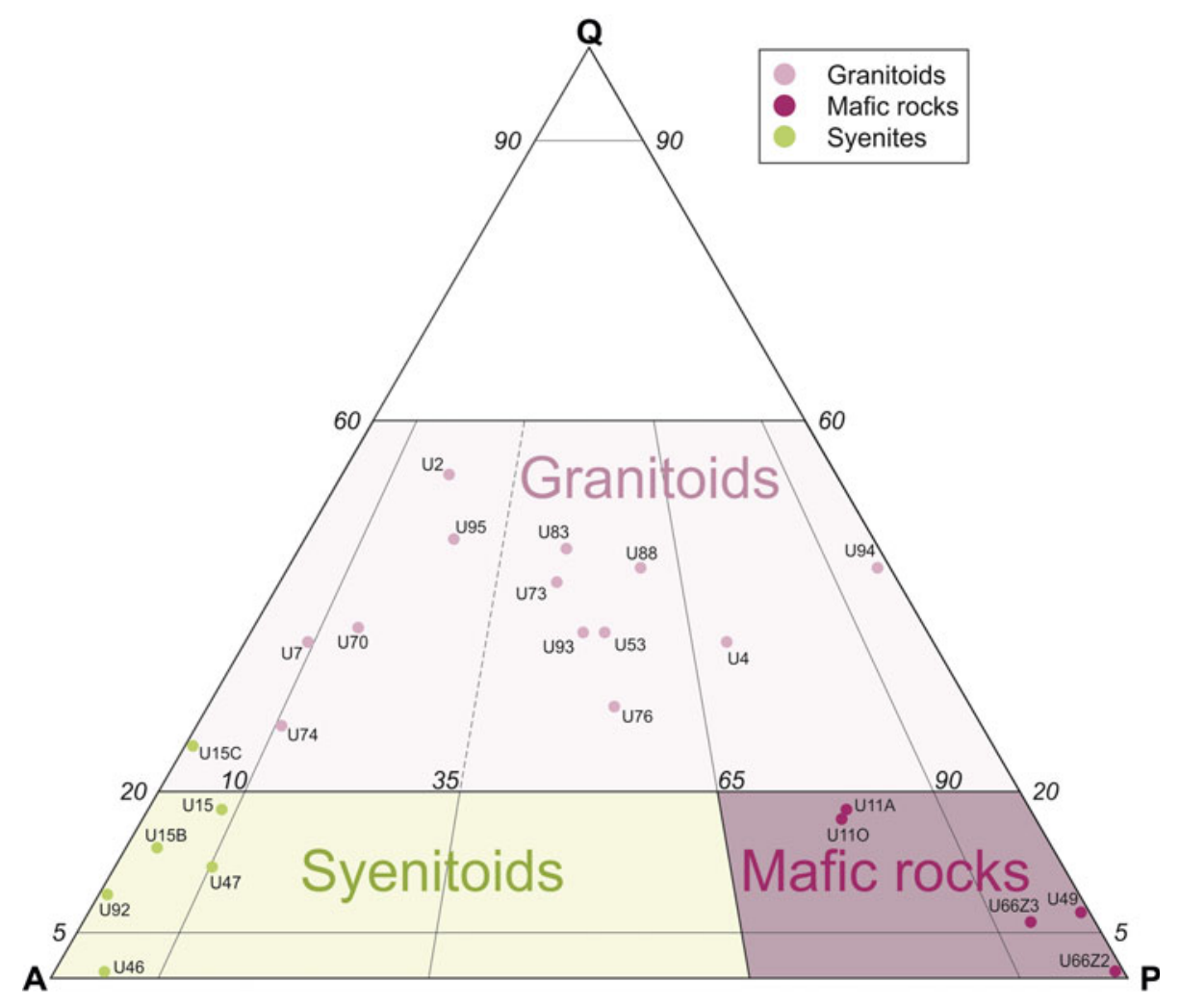

Mahoma Black is classified as a gabbro-norite according to geochemical and petrographical analyses (Oyhantçabal et al. 1990b; Bossi and Schipilov 2007). The mineralogy is composed of plagioclase, orthopyroxene, clinopyroxene, olivine, and spinel, and as accessories pyrrhotite, pentlandite, chalcopyrite, pyrite, marcasite, valleriite, violarite, magnetite, ilmenite, and magnetite (Oyhantçabal et al. 1990b; Bossi and Schipilov 2007).

Arapey Basalt belongs to the Arapey Group, which is composed of several lava flows that show variations in the geochemical and mineralogical composition. In general, the rocks are medium-grained and composed of plagioclase and pyroxene with a subophitic texture (Fig. 10c). Some of the lava flows also contain olivine, granophyric intergrowths, and opaques (Bossi and Schipilov 2007). The analyzed rock belongs to the Itapebí formation (Bossi and Schipilov 2007). Its mineralogy comprises plagioclase, augite, opaques (magnetite and hematite), limonite, and a minor amount of quartz. The augite is partially transformed to limonite; however, finely disseminated limonite is also homogeneously distributed throughout the rock (Table 4). This leads to the assumption that the rock is already partially weathered.

\section{Granitoids}

This group of rocks can be classified by their color in gray, red, and greenish-gray and by their grain size in fine-, medium, coarse-, and very coarse-grained. They have $\mathrm{SiO}_{2}$ values that range from 66.67 to $75.34 \mathrm{wt} \%$, classifying them in the field of acid rocks. $\mathrm{FeO}_{t}$ varies from 1.31 to $3.49 \mathrm{wt} \%, \mathrm{MgO}$ from 0.11 to 1.21 , and $\mathrm{CaO}$ from 0.93 to $4.35 \mathrm{wt} \%$. The total alkalis range from 5.63 to $9.4 \mathrm{wt} \%$, thus these rocks can be classified as transalkaline to calcalkaline or tholeitic (Table 2; Fig. 9).

The mineralogy of the granitoids is represented by alkali feldspar (microcline and orthoclase), sometimes containing perthites (Moskart Granite), plagioclase, quartz, biotite, muscovite, and hornblende (Table 4; Fig. 10). Accessories are magnetite, pyrite, hematite, epidote, apatite, titanite, garnet, stilpnomelane, chlorite, and calcite. Isla Mala is the only granitoid that contains ilmenite. Pyrite is always found as traces. Chamangá Granite is classified as a granodiorite and Isla Mala as a tonalite; the other granitoids that compose this group are classified as granites s.s. (Fig. 8).

Some of these granites show signs of deformation. Cufré Granite shows a complete recrystallization of quartz, evidenced by the very fine-grained texture of this mineral and the absence of undulose extinction (Fig. 10f). The alkali feldspar (microcline) shows incipient recrystallization at the borders of the crystals, but also in thin cracks filled by very fine-grained feldspar crystals along larger crystals. A gentle foliation is observable in the quarry and in extracted blocks, which is determined by the lineation of biotite 
Fig. 9 a Distribution of commercial granites in Uruguay a R1-R2 diagram (after De La Roche et al. 1980), and b TAS diagram (modified after Middlemost 1997; Best 2003). Data of La Paz Granite after Oyhantçabal et al. (1990a, b, 2010); Isla Mala Complex after Preciozzi (1993); Soca Granite after Oyhantçabal et al. (1998); Santa Teresa Granite after Muzio and Artur (1999); Pan de Azúcar Pluton and Maldonado Granite after Oyhantçabal et al. (2007); Mahoma Gabbro-norite and Arapey Basalt after Bossi and Schipilov (2007); Dolerites after Morales Demarco et al. (2011); Cufré and Mahoma Granite after Oyhantçabal et al. (2010); Basalt, granitoids, and syenites this study
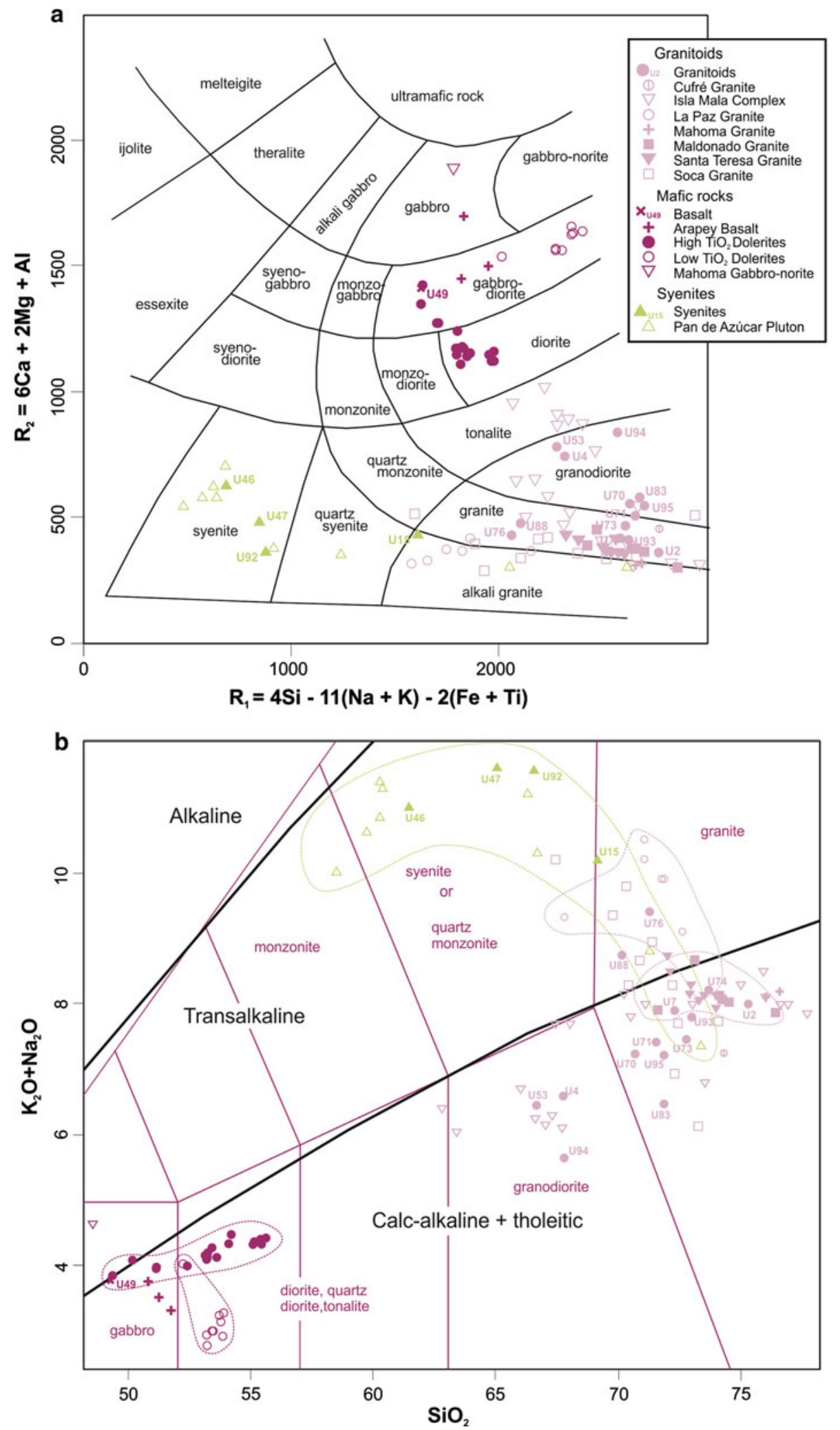

crystals and mafic microenclaves. The Maldonado Granite has undergone a more intense synmagmatic deformation related to the activity of the SBSZ as described by
Oyhantçabal (2005). This granite has a very well-developed foliation, with alternating bands some more rich in biotite and others rich in feldspar and quartz (Fig. 10h). 
Table 2 Major element composition of the commercial granites (in wt\%)

\begin{tabular}{|c|c|c|c|c|c|c|c|c|c|c|c|c|c|c|}
\hline Sample & $\mathrm{SiO}_{2}$ & $\mathrm{TiO}_{2}$ & $\mathrm{Al}_{2} \mathrm{O}_{3}$ & $\mathrm{FeO}_{t}$ & $\mathrm{MnO}$ & $\mathrm{MgO}$ & $\mathrm{CaO}$ & $\mathrm{Na}_{2} \mathrm{O}$ & $\mathrm{K}_{2} \mathrm{O}$ & $\mathrm{P}_{2} \mathrm{O}_{5}$ & $\mathrm{Fe}_{2} \mathrm{O}_{3}$ & $\mathrm{H}_{2} \mathrm{O}$ & $\mathrm{CO}_{2}$ & $\mathrm{Mg} \#$ \\
\hline U11A & 55.43 & 1.73 & 12.94 & 12.54 & 0.17 & 3.04 & 6.97 & 2.58 & 1.75 & 0.22 & 13.93 & 0.63 & 0.13 & 0.20 \\
\hline U11O & 53.22 & 2.33 & 12.16 & 14.50 & 0.18 & 3.07 & 7.25 & 2.56 & 1.64 & 0.25 & 16.11 & 0.59 & 0.09 & 0.17 \\
\hline U66 & 53.19 & 0.74 & 14.98 & 8.82 & 0.15 & 7.13 & 9.74 & 1.87 & 0.91 & 0.10 & 9.80 & 0.82 & 0.29 & 0.45 \\
\hline U49 & 49.27 & 3.51 & 12.38 & 13.96 & 0.21 & 4.72 & 8.67 & 2.44 & 1.33 & 0.46 & 15.51 & 1.14 & 0.08 & 0.25 \\
\hline U2 & 75.34 & 0.24 & 12.48 & 1.58 & 0.04 & 0.27 & 0.93 & 2.77 & 5.22 & 0.07 & 1.76 & 0.56 & 0.11 & 0.15 \\
\hline U4 & 67.75 & 0.46 & 16.45 & 2.66 & 0.05 & 0.99 & 3.45 & 4.74 & 1.83 & 0.14 & 2.95 & 0.78 & 0.17 & 0.27 \\
\hline U53 & 66.67 & 0.52 & 16.34 & 3.11 & 0.06 & 1.21 & 3.73 & 4.60 & 1.84 & 0.17 & 3.46 & 0.92 & 0.17 & 0.28 \\
\hline U70 & 70.71 & 0.34 & 14.23 & 1.97 & 0.05 & 0.73 & 2.22 & 2.69 & 4.53 & 0.10 & 2.19 & 1.24 & 0.79 & 0.27 \\
\hline U71 & 71.59 & 0.34 & 13.94 & 2.02 & 0.05 & 0.60 & 1.87 & 2.65 & 4.76 & 0.13 & 2.24 & 1.18 & 0.49 & 0.23 \\
\hline U73 & 72.8 & 0.25 & 13.70 & 2.21 & 0.03 & 0.38 & 1.66 & 3.58 & 3.87 & 0.07 & 2.45 & 0.73 & 0.19 & 0.15 \\
\hline U83 & 71.9 & 0.23 & 15.00 & 1.85 & 0.03 & 0.41 & 2.51 & 4.48 & 1.98 & 0.07 & 2.06 & 0.66 & 0.34 & 0.18 \\
\hline U93 & 73.00 & 0.28 & 13.70 & 2.03 & 0.06 & 0.36 & 1.16 & 2.94 & 4.84 & 0.18 & 2.26 & 0.79 & 0.20 & 0.15 \\
\hline U94 & 67.8 & 0.42 & 16.00 & 2.97 & 0.05 & 1.15 & 4.35 & 4.41 & 1.22 & 0.12 & 3.30 & 0.70 & 0.18 & 0.28 \\
\hline U95 & 71.9 & 0.26 & 14.50 & 1.69 & 0.04 & 0.53 & 2.24 & 2.91 & 4.29 & 0.08 & 1.88 & 0.87 & 0.31 & 0.24 \\
\hline U7 & 72.3 & 0.36 & 12.22 & 3.49 & 0.05 & 0.11 & 1.59 & 2.34 & 5.54 & 0.07 & 3.88 & 0.67 & 0.37 & 0.03 \\
\hline U74 & 73.7 & 0.23 & 13.30 & 1.80 & 0.03 & 0.17 & 1.33 & 3.48 & 4.72 & 0.05 & 2.00 & 0.45 & 0.23 & 0.09 \\
\hline U76 & 71.3 & 0.27 & 14.40 & 1.31 & 0.02 & 0.47 & 1.15 & 3.71 & 5.69 & 0.10 & 1.45 & 0.47 & 0.34 & 0.26 \\
\hline U88 & 70.2 & 0.36 & 14.10 & 1.85 & 0.01 & 0.64 & 1.56 & 3.86 & 4.87 & 0.14 & 2.05 & 0.68 & 1.15 & 0.26 \\
\hline U15 & 69.2 & 0.26 & 15.49 & 2.09 & 0.06 & 0.21 & 1.09 & 4.55 & 5.65 & 0.06 & 2.32 & 0.64 & 0.11 & 0.09 \\
\hline U46 & 61.48 & 0.61 & 17.72 & 4.17 & 0.14 & 0.48 & 2.36 & 5.82 & 5.17 & 0.14 & 4.63 & 0.59 & 0.20 & 0.10 \\
\hline U47 & 65.06 & 0.33 & 16.41 & 4.19 & 0.16 & 0.04 & 1.44 & 5.34 & 6.76 & 0.03 & 4.66 & 0.71 & 0.13 & 0.01 \\
\hline U92 & 66.6 & 0.29 & 15.10 & 3.94 & 0.13 & 0.01 & 0.62 & 6.11 & 5.44 & 0.02 & 4.38 & 0.47 & 0.24 & 0.00 \\
\hline
\end{tabular}

Table 3 Trace element composition of the commercial granites (in ppm)

\begin{tabular}{|c|c|c|c|c|c|c|c|c|c|c|c|}
\hline Sample & $\mathrm{Ba}$ & $\mathrm{Cr}$ & $\mathrm{Ga}$ & $\mathrm{Nb}$ & $\mathrm{Ni}$ & $\mathrm{Rb}$ & $\mathrm{Sr}$ & $\mathrm{V}$ & $\mathrm{Y}$ & $\mathrm{Zn}$ & $\mathrm{Zr}$ \\
\hline U11A & 485 & 54 & 20 & 11 & 31 & 52 & 207 & 381 & 37 & 115 & 212 \\
\hline U11O & 453 & 25 & 21 & 10 & 25 & 47 & 211 & 404 & 34 & 132 & 195 \\
\hline U66 & 275 & 175 & 16 & 6 & 115 & 16 & 187 & 201 & 16 & 72 & 106 \\
\hline U49 & 384 & 45 & 22 & 23 & 39 & 15 & 439 & 481 & 35 & 143 & 238 \\
\hline $\mathrm{U} 2$ & 225 & 22 & 19 & 14 & 12 & 300 & 50 & 14 & 60 & 41 & 168 \\
\hline U4 & 680 & 27 & 22 & 8 & 11 & 42 & 620 & 29 & 12 & 56 & 224 \\
\hline U53 & 854 & 32 & 21 & 9 & 11 & 37 & 703 & 36 & 14 & 66 & 189 \\
\hline U70 & 569 & 25 & 17 & 9 & 12 & 164 & 152 & 29 & 22 & 23 & 143 \\
\hline U71 & 590 & 21 & 19 & 6 & 14 & 184 & 137 & 31 & 23 & 36 & 160 \\
\hline U73 & 1,160 & 24 & 17 & 13 & 16 & 88 & 160 & 18 & 19 & 49 & 196 \\
\hline U83 & 1,119 & 16 & 18 & 12 & 14 & 57 & 645 & 9 & 9 & 47 & 161 \\
\hline U93 & 293 & 13 & 23 & 21 & 12 & 336 & 72 & 12 & 34 & 48 & 164 \\
\hline U94 & 536 & 24 & 20 & 11 & 23 & 34 & 487 & 42 & 13 & 53 & 128 \\
\hline U95 & 608 & 18 & 17 & 18 & 19 & 170 & 183 & 20 & 26 & 30 & 114 \\
\hline U7 & 1,853 & 20 & 22 & 39 & 12 & 106 & 161 & $<9$ & 91 & 137 & 672 \\
\hline U74 & 449 & 15 & 23 & 18 & 10 & 212 & 129 & 9 & 33 & 40 & 187 \\
\hline U76 & 2,238 & 18 & 22 & 12 & 19 & 151 & 1,002 & 20 & 10 & 35 & 190 \\
\hline U88 & 1,426 & 29 & 25 & 11 & 21 & 176 & 588 & 26 & 9 & 9 & 191 \\
\hline U15 & 725 & 23 & 23 & 42 & 10 & 152 & 174 & 13 & 39 & 62 & 407 \\
\hline U46 & 2,288 & 14 & 23 & 48 & 9 & 53 & 523 & 9 & 39 & 112 & 878 \\
\hline U47 & 164 & 19 & 24 & 42 & 9 & 80 & 33 & $<9$ & 34 & 74 & 557 \\
\hline U92 & 50 & 9 & 36 & 71 & 20 & 122 & 15 & 9 & 69 & 144 & 1,068 \\
\hline
\end{tabular}


The Guazunambí Granite shows deformation features suggesting that it also intruded during the activity of the SBSZ (Bossi and Navarro 2001). In this granite the feldspars are all aligned and define a gentle foliation.

\section{Syenitoids}

This group is characterized by coarse- to very coarsegrained size, normally showing an inequigranular texture and different shades of red and pink color. The geochemistry of the four syenitoid deposits studied is very similar, with values of $\mathrm{SiO}_{2}$ ranging from 61.5 to $69.2 \mathrm{wt} \%$ (i.e., intermediate to acid rocks; Table 2). The values of $\mathrm{Al}_{2} \mathrm{O}_{3}$, $\mathrm{TiO}_{2}, \mathrm{MgO}, \mathrm{CaO}$, and $\mathrm{P}_{2} \mathrm{O}_{5}$ are always higher in the Artigas Pearl. In the Pan de Azúcar White, the $\mathrm{Na}_{2} \mathrm{O}$ content is higher than in any other syenitoid or rock from the other groups considered.

The syenitoids are characterized by low amounts of quartz and plagioclase and high alkali feldspar contents (Table 5). The syenitoids are composed mainly of orthoclase, microcline, and amphiboles, the latter are normally hornblende, but in the Pan de Azúcar White, sodic amphibole (probably riebeckite or arfvedsonite) is the main amphibole found. Other minerals that occur in these rocks appear as accessories: plagioclase, quartz, biotite, chlorite, pyroxene (normally aegirine-augite), ferristilpnomelane, calcite, epidote, tourmaline, magnetite, and zircon. Artigas Pearl shows traces of
Fig. 10 Thin section images of black and gray commercial granites, image width approximately $8.7 \mathrm{~mm}$. a Fine-grained Absolute Black Dolerite (U11A) in plane polarized light (PPL) with a subophitic texture between Pl and Aug; b Moderate Black Dolerite (U11O) of Group A (high TiO2) in PPL, medium grain size and subophitic texture; c Arapey Basalt (U49) in PPL with medium-grained subophitic texture; d Cerro Áspero Granite (U70) in cross polarized light (CPL), fine- to medium-grained texture with Or and Qtz; e Chamangá Granite (U4) in CPL medium-grained texture with Qtz, $\mathrm{Pl}$, Or, and $\mathrm{Bt}$; f Cufré Granite (U73) in CPL, to the right recrystallized Qtz (fine-grained) and to the left a Mc phenocryst; g Cuchilla del Perdido Granite in CPL, medium-grained texture, Qtz, $\mathrm{Pl}$, Or, and Bt; and $\mathbf{h}$ Maldonado Granite in CPL, phenocrysts of Or and $\mathrm{Mc}$ in recrystallized matrix of Qtz with Bt. Abbreviations after Kretz (1983) except the ones marked with asterisk: Aug augite, Bt biotite, $\mathrm{Lm}$ limonite, $\mathrm{Mc}$ microcline, $\mathrm{Or}$ orthoclase, $\mathrm{Pl}$ plagioclase, Qtz quartz

pyrite. Based on their mineralogical composition, these rocks can be classified as alkali feldspar syenite, quartz alkali feldspar syenite, and quartz syenites (Fig. 8).

\section{Technical aspects}

Color and décor

The black and dark gray color characterizes the mafic rocks mined in Uruguay. Other mafic rocks with different colors
Table 4 Modal composition of the commercial granites studied

Abbreviations after Kretz (1983) except the ones marked with asterisk: $A b$ albite, $A m p h^{*}$ amphibole, Aug augite, $B t$ biotite, $\mathrm{Cal}$ calcite, $\mathrm{Chl}$ chlorite, Festil* ferristilpnomelane, $G r$. Int. * graphic intergrowth, $\mathrm{Hbl}$ hornblende, $L m$ limonite, $M c$ microcline, $M s$ muscovite, $O P^{*}$ opaques, $\mathrm{Or}$ orthoclase, $\mathrm{Pl}$ plagioclase, $Q t z$ quartz

\begin{tabular}{|c|c|c|}
\hline ID & Commercial name & Modal analysis (vol\%) \\
\hline U11A & Negro Absoluto Dolerite & 37Pl, 33Aug, 20Gr.int., 9Op \\
\hline U11O & Negro Oriental Dolerite & 41Pl, 29Aug, 3Hbl, 22Gr.int., 5Op \\
\hline U66A & Pimafox fine-grained & 58Pl, 42Aug, Op \\
\hline U660 & Pimafox coarse-grained & 47Pl, 42Aug, 6Gr.int., 1Op \\
\hline U49 & Arapey & 3Qtz, 40Pl, 31Aug, 17Lm, 9Op \\
\hline $\mathrm{U} 2$ & Maldonado & $51 \mathrm{Qtz}, 34 \mathrm{Mc}, 10 \mathrm{Pl}, 5 \mathrm{Bt}$ \\
\hline $\mathrm{U} 4$ & Chamangá & 31Qtz, 9Or, 7Mc, 38Pl, 15Bt \\
\hline U53 & Cuchilla del Perdido & 33Qtz, 26Or, 29Pl, 10Bt, 1Aug, lHbl \\
\hline $\mathrm{U} 70$ & Cerro Áspero & 30Qtz, 36Or, 6Mc, 8Pl, 12Bt; 7Ms, ICal \\
\hline $\mathrm{U} 73$ & Cufré & 40Qtz, 1Or, 29Mc, 24Pl, 6Bt \\
\hline U83 & Goñi & 45Qtz, 28Or, 24Pl, 3Bt \\
\hline U92 & Pan de Azúcar & 8Qtz, 80Or, $11 \mathrm{Hbl}$ \\
\hline U93 & Santa Teresa & 18Qtz, 63Mc, 10Pl, 9Bt \\
\hline U94 & Isla Mala & 42Qtz, 1Mc, 53Pl, 4Bt \\
\hline U95 & Garzón Granite & 46Qtz, 32Or, 6Mc, 13Pl, 3Bt \\
\hline $\mathrm{U} 7$ & Moskart & 41Qtz, 46Mc, 8Pl, 1Hbl, 2Festil, 2Op \\
\hline $\mathrm{U} 74$ & $\mathrm{La} \mathrm{Paz}$ & 25Qtz, 60Mc, 7Pl, 7Bt, 1Hbl \\
\hline U76 & Guazunambí & 27Qtz, 15Or, 16Mc, 36Pl, 4Bt, 1Aug, ICal \\
\hline U88 & Mahoma Red & 41Qtz, 7Ort, 63Mc, 30Pl, 6Bt \\
\hline $\mathrm{U} 15$ & Salmon Red & 12Qtz; 71Or, 13Pl, 2Hbl, IChI, 1Festil \\
\hline U46 & Artigas Pearl & 86Or, 5Pl, 4Hbl, 5Festil \\
\hline U47 & Violeta Imperial & 11Qtz, 67Or, 7Pl, 8Hbl, 1Lm, 1Aug, 2Op, 3Festil \\
\hline
\end{tabular}



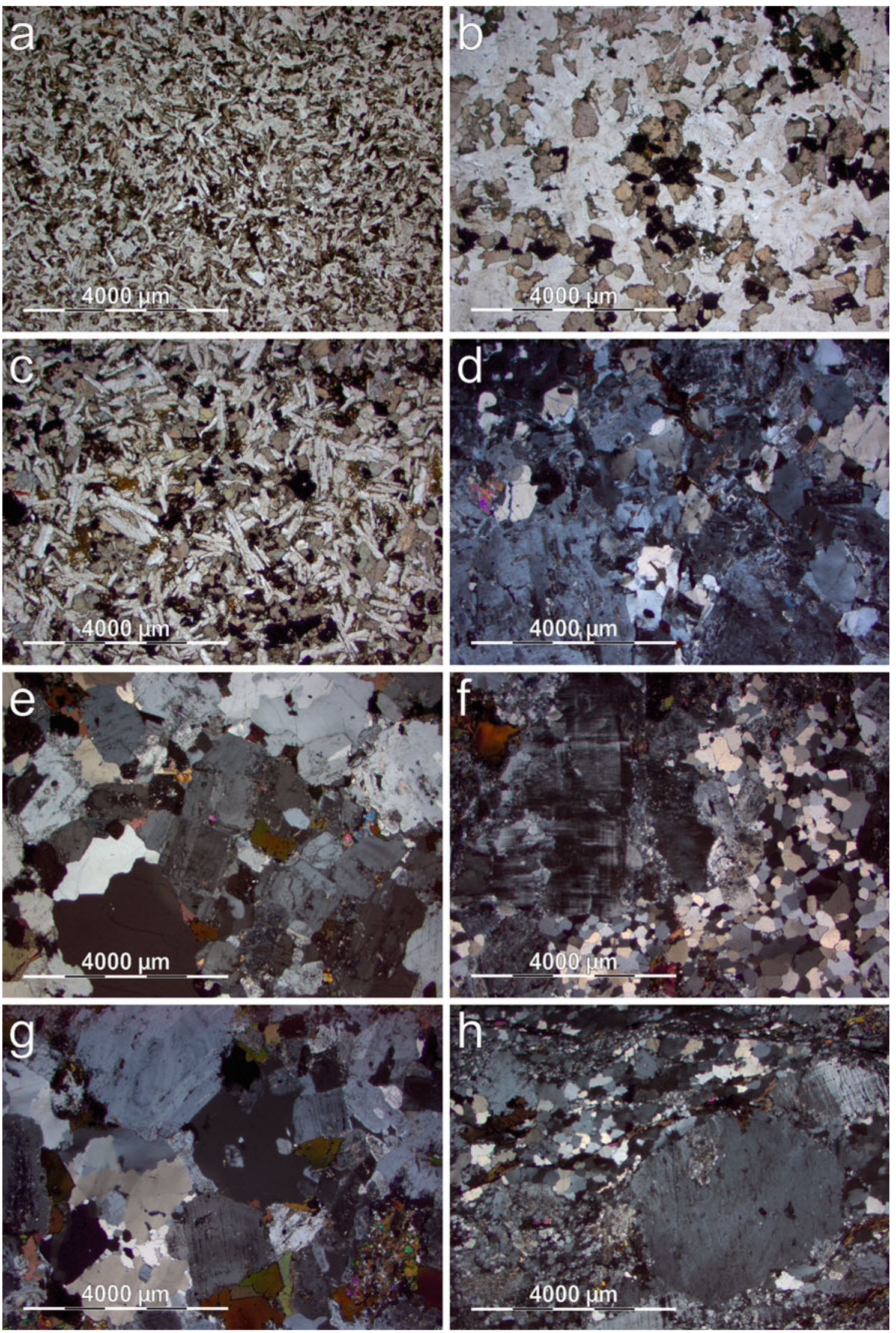
Table 5 Block volume calculated using different methods
* Cufré Granite quarry data may not be representative of the whole deposit

\begin{tabular}{lllll}
\hline Quarries & ID & \multicolumn{2}{l}{ Block size Vb $\left(\mathrm{m}^{3}\right)$} & \\
\cline { 4 - 5 } & & $\begin{array}{l}\text { Singewald } \\
\text { method }\end{array}$ & $\begin{array}{l}\text { Palmstrøm } \\
\text { method }\end{array}$ & $\begin{array}{l}\text { Sousa } \\
\text { method }\end{array}$ \\
\hline Sacramento Dolerite lower floor & U8_lf & 3.73 & 4.12 & 2.51 \\
Sacramento Dolerite upper floor & U8_uf & 1.03 & 1.15 & 0.65 \\
Maldonado Granite lower floor & U2_lf & 0.35 & 0.38 & 0.12 \\
Maldonado Granite upper floor & U2_uf & 0.43 & 0.41 & 0.17 \\
Chamangá Granite & U4 & 13 & 12 & 8 \\
Cerro Áspero Granite (quarry 193) & U70_193 & 2.81 & 3.01 & 0.86 \\
Cerro Áspero Granite (quarry 192) & U70_192 & 6.16 & 6.84 & 3.27 \\
Cufré Granite* & U73 & 689 & 756 & 163 \\
Moskart Granite & U7 & 10.6 & 8.0 & 1.8 \\
Salmon Red Syenite (quarry 075) & U15_075 & 1.14 & 1.23 & 0.40 \\
Salmon Red Syenite (quarry 079) & U15_079 & 8.83 & 9.38 & 4.89 \\
Artigas Syenite lower floor & U46_lf & 1.53 & 1.71 & 0.20 \\
Artigas Syenite upper floor & U46_uf & 5.60 & 6.21 & 2.14 \\
Artigas Syenite boulder zone & U46_b & 37.1 & 38.3 & 38.1 \\
Violeta Imperial Syenite & U47 & 2.64 & 2.78 & 0.47 \\
\hline
\end{tabular}

have never been mined. The black and gray colors are determined by a relatively high proportion of mafic minerals (e.g., pyroxenes, amphiboles, opaque minerals). Bossi and Campal (1991) classified the dolerites according to their grain size and their black color quality. The most valuable dolerite is the Absolute Black variety (Fig. 10a), which is defined by its deep black color and a fine-grained subophitic texture. Its color is very homogeneous not only due its texture but also due to the lack of veins. It has only been found in a small proportion of the deposits in Group A (Morales Demarco et al. 2011). The dark gray variety, which is characterized by a medium-grained subophitic texture, is known as Moderate Black, Negro Oriental, or Sacramento (Fig. 10b) and is found in groups A and B. Its décor is sometimes interrupted by white spots due to the presence of millimeter-sized granophyric intergrowths. Light gray aplitic veins up to five centimeter in thickness are sometimes observable, but these can be easily avoided during the mining process.

Mahoma Black is a dark gray fine- to medium-grained gabbro-norite (Oyhantçabal et al. 1990b). The presence of sulfides in this rock (Oyhantçabal et al. 1990b; Bossi and Schipilov 2007) limits its use as a dimensional stone to indoor applications, where weathering processes do not alter its color or change the petrophysical and petromechanical properties.

The granitoids can be further classified according to two specific fabric features: grain size (fine, medium-, and coarse-grained) and the relationships between the mineral components (equigranular, porphyritic, etc.). The gray granitoids owe their color to the relatively high amount of limpid and gray feldspar, quartz, low amounts of mafic minerals, and the absence of iron hydroxides (e.g., limonite). They can be sub-classified into: (i) fine-grained (Cerro Áspero and Garzón), (ii) medium-grained (Chamangá, Cuchilla del Perdido and Cufré), and (iii) very coarse-grained (Maldonado and Santa Teresa). Cufré Granite shows recrystallization of quartz grains and a gentle foliation. The coarse-grained granites also have a porphyritic texture with a preferred orientation of the phenocrysts (Muzio and Artur 1999; Oyhantçabal 2005).

The Uruguayan red granites show a color range between carmine red and carmine pink, with small variations within a same variety. The red color in granitoids has been related to the presence of ferric iron oxides in the alkali feldspars, especially hematite (Boone 1969; Taylor 1977; Nakano et al. 2002; Putnis et al. 2007; Plümper and Putnis 2009). Plümper and Putnis (2009) studied the re-equilibration of feldspars in the presence of a fluid phase in gray and red stained granites from southeast Sweden. They determined a three stage feldspar replacement within these rocks: (i) the first stage consists of a replacement of original microcline by oligoclase due to fluid circulation (in the late magmatic stage) with a concomitant porosity development within the oligoclase; (ii) a second stage is characterized by the circulation of Na-enriched hydrothermal fluid leading to a replacement of the oligoclase by albite and sericite formation within the albite pores; and (iii) the third stage includes fracturing and infiltration of a K-rich fluid that causes the K-feldspathization of sericite and albite with hematite precipitation in the orthoclase pores that produces the red coloration. 
In all the Uruguayan red granites evidence of these feldspar replacements can be observed. In the Mahoma Red Granite, for example, the plagioclase contains sericite and calcite inclusions, as well as microcline relicts. The plagioclase is partially replaced by perthitic orthoclase and both feldspars show a red stain, probably due to precipitation of hematite (Fig. 11). The red granites are either medium-grained, with equigranular texture (Mahoma Red Granite, equigranular facies of the La Paz Granite) or medium to coarse-grained, with porphyritic texture (porphyritic facies of the La Paz Granite, Preciozzi et al. 1985; Oyhantçabal et al. 1990a) and eventually show a slightly orientation of their phenocrysts (Guazunambí and Luján Granites).

Moskart Granite is greenish-gray to brownish-gray and very coarse-grained (Fig. 11c, d), with small variations of color in the area of the deposit. Bossi et al. (1965) attributed its color to the growth of biotite and chlorite in the cleavage planes of microcline. On the other hand, Oyhantçabal et al. (1998) suggested that a secondary paragenesis (stilpnomelane, chlorite, calcite, and bluish green amphibole) related to the activity of the SYSZ generates the color. The rock actually shows evidence of similar feldspar replacement as described for the red granites but without the precipiatation of hematite. It can also be observed in the gray non-commercial variety and the greenish-gray variety (commercialized as Moskart Granite) (Fig. 11c, d). The main difference between these two color varieties is not the proportion of the feldspar replacement. The greenish-gray color of the commercial variety (Moskart Granite) is related to the presence of microcracks filled by chlorite, sericite, calcite, and limonite. The differences in the distribution and proportions of these minerals determine the color variations observed in the quarries and in the commercialized Moskart Granite varieties.

All these granites can show structural elements that disrupt their décor. The most frequent disruptions are due to mafic enclaves, biotite accumulations, mafic and aplitic dikes, schlieren, synmagmatic and convolute layering.

As already described and illustrated by previous authors (Comunità Economica Europea-Uruguay no date, Bossi and Navarro 2000; Oyhantçabal et al. 2007) the colors of the syenitoids are dark salmon, pink salmon, and terracotta with white spots (Salmon Red), pale red-violet (Violeta Imperial), and light gray with black spots (Pan de Azúcar White). Artigas Pearl shows a distinct décor and color, where bluish-gray feldspar crystals (up to $35 \mathrm{~mm}$ ), sometimes showing iridescence, are surrounded by a pink to intense crimson rim in their contact with the agglomerations of mafic minerals (up to $1 \mathrm{~cm}$ ). This kind of color combination is relatively seldom in magmatic rocks. It optically attenuates and softens the intense coarse-grained texture, so that this rock will be preferably used for eyecatching applications such as countertops and façades.

In these rocks the same feldspar replacements are observable as in the red and greenish-gray granites (Fig. 11e-h). Other evidences of hydrothermal alteration are the presence of biotite partially altered to chlorite, epidote, and calcite (e.g., in the Red Salmon Syenite).

Salmon Red, Violeta Imperial, and Pan de Azúcar White are coarse-grained, whereas Artigas Pearl is very coarsegrained and has a porphyritic texture (Fig. 11e, f). The texture is seriated in Salmon Red (Fig. 11g, h), Violeta Imperial, and Pan de Azúcar White syenitoids, with feldspar crystals between 4 to $15 \mathrm{~mm}$ in size. All the syenitoid deposits show occurrences of narrow schlieren (up to $5 \mathrm{~mm}$ ), thin mafic dikes, or aplitic veins, but only the Salmon Red and Violeta Imperial contain mafic enclaves. Due to the special décor of these rocks, small changes in mineralogy and alteration (hydrothermal and weathering) can lead to very visible changes in color and fabric. The case of the Artigas Pearl is a good example, since its décor varies from the more typical variety (Fig. 12a) to the very intense red or darker gray varieties (Fig. 12b, c), which modifies the market value of this rock.

\section{Petrophysical and petromechanical properties}

The potential uses of the dimensional stones can be deduced from their physical and mechanical properties, which in turn are closely related with their petrography and degree of weathering. As discussed in detail in numerous publications (See Siegesmund and Dahms 1994; Strohmeyer 2003; Rüdrich 2003; Koch 2005; Hoffmann 2006; Mosch 2008), the majority of the rocks when considering their fabric are anisotropic, and therefore, some of their physical properties are directionally dependent. In order to identify possible anisotropies these properties were measured in three orthogonal directions. In the following subchapter just their mean values will be discussed. All the other data are listed in the appendix (Tables A.1-A.4).

\section{Density and porosity}

The bulk density of the Uruguayan commercial granites, measured using the Archimedes method, as described in Monicard (1980), vary from $2.61 \mathrm{~g} / \mathrm{cm}^{3}$ for the Salmon Red Syenite and $3.02 \mathrm{~g} / \mathrm{cm}^{3}$ for the Moderate Black Dolerite (Table A1). All other Uruguayan commercial granites are in the above given range and in accordance with the values given in the compilation by Mosch and Siegesmund (2007) (Fig. 13a) and Siegesmund and Dürrast (2011). The mafic rocks show the higher matrix density values 



determined by the higher proportion of heavier elements (mainly iron, calcium, and titanium) forming minerals such as plagioclase, mafics, and opaque minerals. The granitoids

and syenitoids have lower amounts of these elements and higher proportions of the lighter elements (such as silicon and sodium), and therefore, show lower matrix densities. 
४Fig. 11 Thin section images of colored commercial granites. a Mahoma Red Granite (U88) in cross polarized light (CPL), Or has partially substituted $\mathrm{Pl}$, as evidenced by sericitization in the center of the image; $\mathbf{b}$ close-up of the previous image where Mc relicts partially surrounded by $\mathrm{Cal}$ are recognized in new formed Or; $\mathbf{c}$ gray variety of Moskart Granite in CPL, Pl with intense sericitization, and relicts of Mc; d Moskart Granite (U7) in CPL, Qtz, Mc, and Pl compose the rock, intra and intercrystalline microcracks are filled by $\mathrm{Chl}, \mathrm{Bt}$, Ser, $\mathrm{Cal}$, and Lm; e Artigas Pearl Syenite (U46) in plane polarized light (PPL), observe the reddening of Or crystals in contact with ferromagnesian agglomerations; $\mathbf{f}$ same as e but in CPL; $g$ Salmon Red Syenite (U15) in PPL, Pl with sericitization and partially altered to Or, in top of image Bt partially altered to Chl, and numerous Op grains; and $\mathbf{h}$ same as $\mathbf{g}$ but in CPL. Abbreviations after Kretz (1983) except the ones marked with asterisk: $A b$ albite, $A m p h^{*}$ amphibole, Aug augite, Bt biotite, Cal calcite, Chl chlorite, Festil* ferristilpnomelane, Gr. Int.* graphic intergrowth, $\mathrm{Hbl}$ hornblende, $\mathrm{Lm}$ limonite, $M c$ microcline, $M s$ muscovite, $\mathrm{Op}^{*}$ opaques, $\mathrm{Or}$ orthoclase, $\mathrm{Pl}$ plagioclase, $Q t z$ quartz; *Ser sericite

The water that a dimensional stone is capable to absorb and retain in the pore spaces, as well as its mobility within the pore network plays an important role in the weathering process and the petrophysical behavior (Peschel 1977; Weiss 1992; Siegesmund and Dürrast 2011). Porosity, pore radii distribution, water uptake and capillary water uptake, and water vapor diffusion were determined in the samples studied to evaluate their durability when applied for constructive purposes (Table A.1).

The porosity was also measured by the method described in Monicard (1980). In respect to this property all the mafic rock and syenitoid samples analyzed are outliers in the distribution of their respective groups as determined by the statistical compilation of Mosch and Siegesmund (2007) (Fig. 13b). The lower values, between 0.03 and $0.12 \%$, are registered by the dolerites (e.g., Absolute Black). They have a very compact fabric, where the interstitial space of the fine-grained subophitic texture is completely filled by granophyric intergrowths. The Arapey Basalt with a similar fabric shows a porosity of $0.98 \%$, the highest value in the mafic rock group. This fact is considered to be a consequence of the relatively altered or weathered condition of the Arapey Basalt samples studied as indicated by the presence of limonite and microcracks in plagioclase and pyroxene.

The granitoids have intermediate porosities, showing values between 0.27 (Chamangá Gray Granite) and $0.80 \%$ (Cerro Áspero Granite). The syenitoids show the highest porosity values of the different commercial granites considered, where the highest porosity value was registered by the Violeta Imperial Syenite: $1.34 \%$. This rock, as in the other syenitoids studied, shows a more open interstitial space, where the feldspars show a complex replacement history (e.g., relict microcline in plagioclase showing albitization). The matrix is composed of a mixture of amphibole, pyroxene, chlorite, ferristilpnomelane, and epidote, which indicates hydrothermal alteration and accounts for the higher porosity values measured.

The pore size distribution determined by mercury injection porosimetry shows a low variation between the different groups considered (Table A1). The porosity of the dolerites is so small that the pore radii distribution is difficult to measure; these rocks have mean pore size values between 0.032 (Arapey Basalt) and $0.209 \mu \mathrm{m}$ (Pimafox Oriental Dolerite). Granitoids and syenitoids show a similar mean pore size, e.g., the fine-grained variety Cerro Áspero Gray has an average pore radius of $0.09 \mu \mathrm{m}$ and Artigas Pearl Syenite $0.08 \mu \mathrm{m}$. The most frequent pore radii are also very similar between all the rocks analyzed: between 0.008 (Artigas Pearl Syenite and Moskart Granite) and $0.335 \mu \mathrm{m}$ (Violeta Imperial Syenite). The pore size distribution has a significant influence on the water uptake and the capillary water uptake.

The capillary water absorption, which was determined following the DIN EN 13755 (2008) and DIN EN 12670 (2001) is the main mechanism acting in pores with a radius between $0.1 \mu \mathrm{m}$ and almost $1 \mathrm{~mm}$ (Siegesmund and Dürrast 2011). Since there is no water circulating in the pores the interactions between the rocks and the building materials (e.g., mortar) are insignificant, as well as the weathering processes that leads to the decay of the commercial granites. This is especially true for the dolerites and granitoids, which show extremely low porosity and capillary water absorption.

The water absorption (or water uptake) of the studied commercial granites is very low, in accordance with the very low porosity (Table A.1). The dolerites show extremely low unforced water absorption values between 0.01 and $0.03 \mathrm{wt} \%$, whereas the basalt has $0.28 \mathrm{wt} \%$ due to its higher porosity. The granitoids show intermediate values between 0.07 and $0.27 \mathrm{wt} \%$ and the syenitoids between 0.30 and $0.43 \mathrm{wt} \%$.

Water absorption values for granites are between 0.1 and 1.5 wt\% (Peschel 1977). The DIN 52008 defines that rocks with water absorption at atmospheric pressures (or unforced water absorption) less than $0.5 \mathrm{wt} \%$ are weathering resistant, as is the case for all Uruguayan commercial granites.

Fine-grained gray granites like the Cerro Áspero Gray (U70) are in demand because of their low water absorption (0.12-0.09, See Table A.1). The market for this kind of rock is led by the Chinese commercial granite Padang Light (G3533/G633). The data available for this granite are doubtful (Börner and Hill 2010) and lower (0.36 wt\%; Table A.1) than in the unpublished reports from different Chinese providers, where the water absorption of Padang Light Granite ranges from 1.5 to $3.0 \mathrm{wt} \%$. The comparable granite from Uruguay, Cerro Áspero Granite, develops a lower amount of staining or spots due to its lower water absorption. 



Fig. 12 Different colors and décors in the Artigas Pearl Syenite (slab length $=10 \mathrm{~cm}$ )

The saturation coefficient $\mathrm{S}$ is the relation between the unforced water absorption and the forced water absorption, as defined by Hirschwald (1912). The author related this value with the capacity of a rock to resist weathering and freezing. All Uruguayan commercial granites show a very high $S$ value, but as described in Siegesmund and Dürrast (2011), this coefficient has little application in the case of plutonic and metamorphic rocks with a bulk density higher than $2.6 \mathrm{~g} / \mathrm{cm}^{3}$. This assumption is derived from the fact that the porosity of these rocks tends to be very low, and therefore, their capacity to interact with water. This lack of interaction between the rock and water leads to a better rock stability against weathering and freezing.
Water vapor diffusion

The highest vapor diffusion value indicates the higher resistance of the rock to the transmissivity of water, therefore the lowest permeability. The dolerites show the highest mean values, between 5,472 for Moderate Black and 6,713 (dimensionless) for Absolute Black (Table A.2). Granitoids and syenitoids show similar values, with the exception of the Maldonado Granite, which has the lowest value of 83 in the $x$-direction due to its fabric anisotropy. The other rocks in these groups show values between 374 (Moskart Granite) and 1,508 (Salmon Red Syenite). The values obtained in the present research for granitoids and syenitoids are in the range of those published by 
Fig. 13 Box plots of some petrophysical properties of commercial granites worldwide (redrawn after Mosch 2008) and Uruguay (each colored dot represents an average value) c uniaxial compressive strength (UCS); d flexural strength; and e tensile strength a bulk density; b porosity;
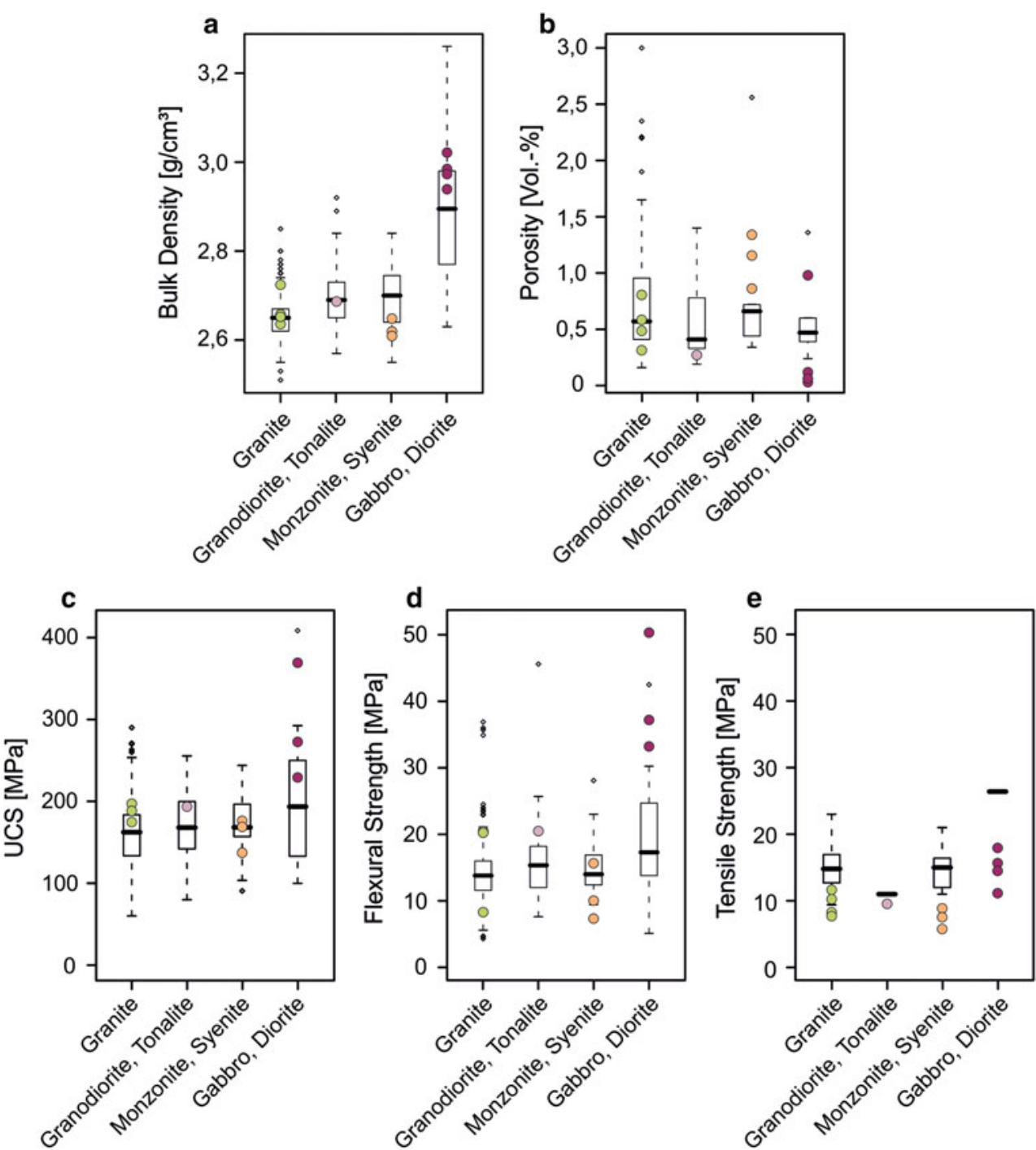

Siegesmund and Dürrast (2011) which measured values between 811 and 3,869 for plutonic rocks.

In applications where the water vapor diffusion can have an impact, such as façades and fountains, the anisotropy of this petrophysical property should be taken into account. One example is the Maldonado Granite, which has an anisotropy of 1:3:3 in the $x$-, $y$-, and $z$-direction. Therefore, considering the direction of the cut is necessary.

Ultrasonic wave velocities

In addition to the static Young's modulus, it has become commonplace to determine the dynamic Young's modulus by measuring the ultrasonic velocity for evaluating the degree of structural damage in dimensional stones (Köhler 1991; Siegesmund and Dürrast 2011). Under dry conditions the Vp (compressive waves) velocities should be above $5 \mathrm{~km} / \mathrm{s}$ in unweathered granitoids (Illiev 1967).
The Uruguayan commercial granites show ultrasound velocities (Vp) between $3.38 \mathrm{~km} / \mathrm{s}$ (Cerro Áspero Granite in $z$-direction) and $6.49 \mathrm{~km} / \mathrm{s}$ (Moderate Black Dolerite in $y$-direction). The mafic rocks show the higher ultrasound values, between 5.41 and $6.49 \mathrm{~km} / \mathrm{s}$ and the granitoids and syenitoids intermediate ones, between 3.38 and $5.85 \mathrm{~km} / \mathrm{s}$. The only samples showing anisotropy values higher than $10 \%$ are Maldonado Gray Granite, with around $10 \%$ anisotropy and around $21 \%$ in the Cerro Áspero Gray Granite.

Sampling was carried out in quarries, exclusively in fresh rocks, with the exception of the Arapey Basalt, where this was not possible. The values presented here can be used as standards for comparative measurements of fresh and unweathered rocks. Dolerites show the most remarkable values, where the anisotropy is very low $(2-3 \%)$ as indicated by the homogeneous fabric in these rocks. 

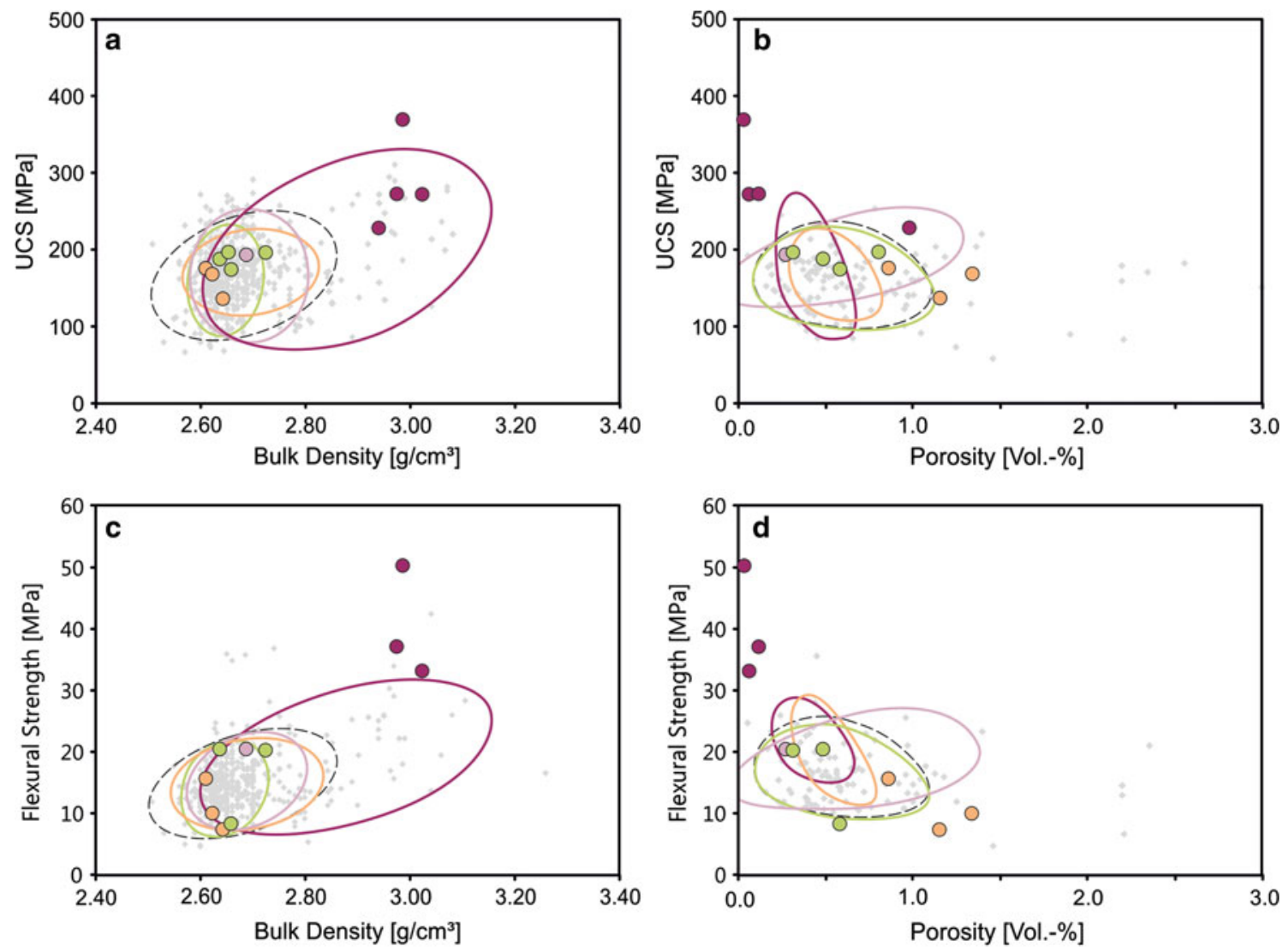

5. Plutonite total $\bigcirc_{\odot}$ Gabbro, Diorite $\bigcirc_{\bigcirc}$ Granite $\bigcirc_{\bigcirc}$ Granodiorite, Tonalite $\bigcirc_{\bigcirc}$ Monzonite, Syenite

Fig. 14 Statistical values of some petrophysical properties of commercial granites worldwide (gray dots and ellipses after Mosch (2009). The ellipses represent $80 \%$ of the expected values for each rock group) and Uruguay (each colored dot represents an average

\section{Thermal expansion}

Numerous dimensional stones have a weathering sensitivity/vulnerability against thermal stresses, caused by an expansion of the material at high temperatures and a contraction with subsequent cooling. The thermal expansion is essentially controlled by the mineralogical composition and fabric of the rock (Koch and Siegesmund 2004; Koch 2005; Siegesmund et al. 2008).

In granites the thermal expansion and its associated processes (e.g., progressive microcracking leading to bowing) are more complex than in marbles. This is mainly due to the monomineralogical composition of marbles (calcite or dolomite), in contrast to granites that have at least three minerals present or generally more. Each mineral has a different thermal expansion and some of them are anisotropic with respect to this property. Quartz has the lowest thermal expansion coefficient $(\alpha)$ parallel to the $c$-axis $\left(7.7 \times 10^{-6} \mathrm{~K}^{-1}\right)$ and the highest perpendicular to it $\left(\alpha=13 \times 10^{-6} \mathrm{~K}^{-1}\right)$ (Siegesmund et al. 2008). Biotite is value of a commercial granitic stone) a bulk density versus uniaxial compressive strength (UCS), b porosity versus uniaxial compressive strength, $\mathbf{c}$ bulk density versus flexural strength, and $\mathbf{d}$ porosity versus flexural strength

also anisotropic with $\left(\alpha=17.3 \times 10^{-6} \mathrm{~K}^{-1}\right)$ parallel to the $c$-axis and $9.7 \times 10^{-6} \mathrm{~K}^{-1}$ perpendicular to it (Siegesmund et al. 2008). High plagioclase contents lead to low $\alpha$ values, due to the extremely small volume expansion of this mineral (Weiss et al. 2004).

Castro de Lima and Paraguassú (2004) analyzed the thermal expansion coefficient $(\alpha)$ of 19 commercial granites and concluded that an increment in porosity leads to a decrease in $\alpha$, whereas an increment in grain size or quartz content increases $\alpha$. These authors also analyzed the directional dependency of $\alpha$, concluding that for the samples studied there is no dependency.

The thermal expansion coefficient $(\alpha)$ for the commercial granites varies from 5.74 (Artigas Pearl in the $x$-direction) to $9.47 \times 10^{-6} \mathrm{~K}^{-1}$ (Moskart in the $y$-direction) (Table A.2). The range of values obtained is comparable with those reported for magmatic rocks by Strohmeyer (2003), Hoffmann (2006), Weiss et al. (2004), Siegesmund et al. (2008), and Vázquez et al. (2011). The mafic rocks show the lowest mean $\alpha$, since these rocks show the lowest 
Fig. 15 a Stereogram of the Salmon Red Syenite deposit; b theoretical model of the joint sets affecting the Salmon Red deposit; c raw block resulting from the presence of the joint sets and possible block resulting from its squaring; d stereogram of the Moskart Granite deposit; e theoretical model of the joint sets affecting the deposit; and f raw block and finished block as a result of squaring
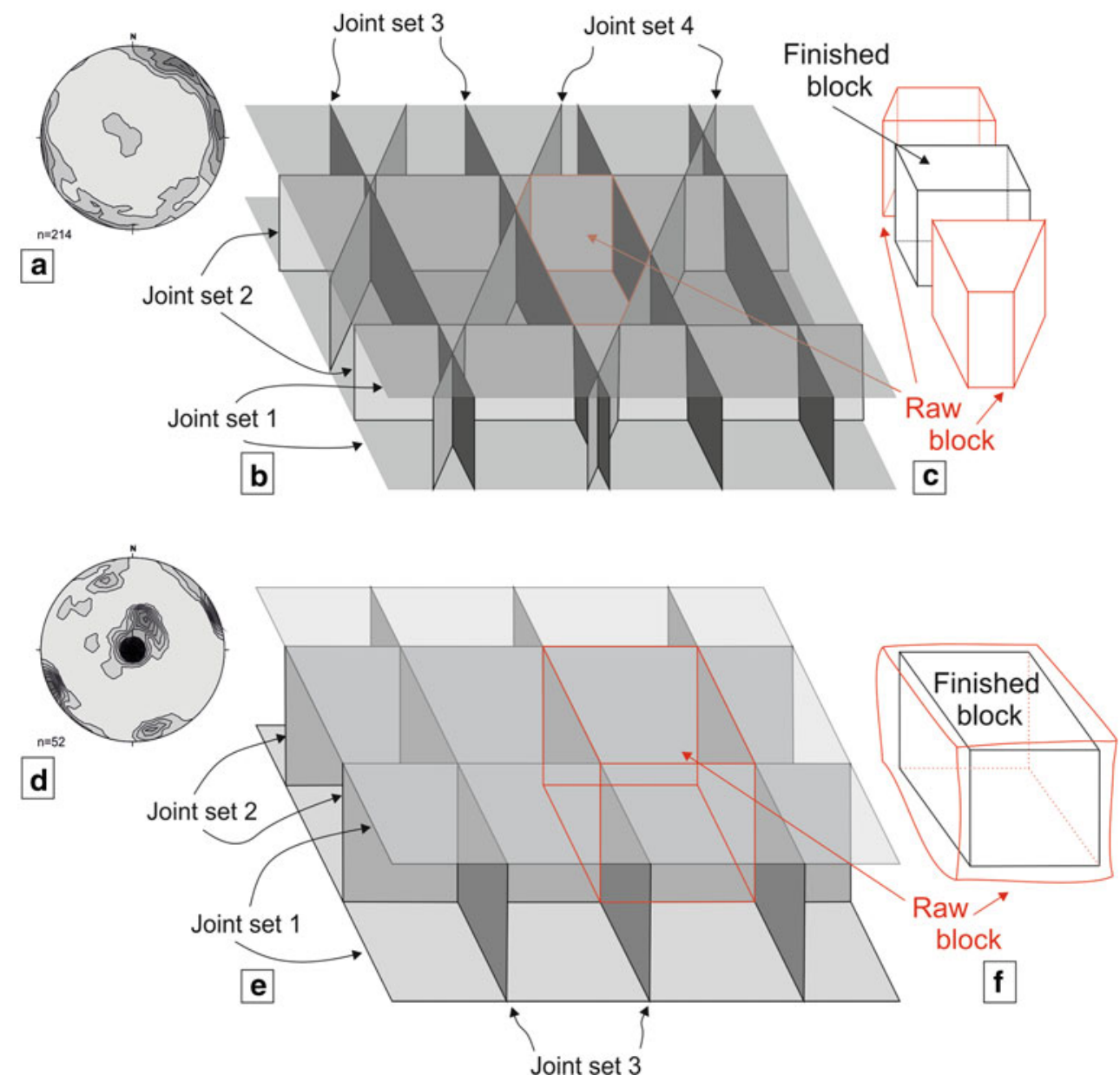

mean grain size and quartz content, and the highest proportion of plagioclase. Granitoids show the highest mean $\alpha$ value and the highest quartz content. The syenitoids, with intermediate $\alpha$ values, show a low proportion of quartz and the highest porosity values. These relationships are in accordance with the observations made by Castro de Lima and Paraguassú (2004) and Vázquez et al. (2011).

Generally, the samples show anisotropies lower than $11 \%$ in their thermal expansion, but there are two cases where higher anisotropies were measured: Artigas Pearl Syenite $(15 \%)$ and Moskart Granite (18\%). Both commercial granites are very coarse-grained. A similar behavior was reported by Vázquez et al. (2011) in three coarse- to very coarse-grained commercial granites.

Differential deterioration can occur in light-colored granitoids with dark-colored enclaves or xenoliths due to the albedo effect or differential thermal response to insolation (Gómez-Heras et al. 2006; Steiger et al. 2011). The deterioration will generally be expressed by the spalling of enclaves or xenoliths (Gómez-Heras et al. 2006).

The thermal expansion behavior of a dimensional stone is closely related to its bowing behavior when applied as slabs for outdoor façade cladding (Siegesmund et al. 2008; Vázquez et al. 2011). For bowing the same factors influencing thermal expansion are relevant: coarse- to very coarse-grained texture, mineral shape-preferred orientation and porosity (Vázquez et al. 2011).

When considering a building application with thermal exposure from one direction (e.g., façades), the rocks showing a high anisotropy in thermal expansion and flexural strength should be used in the most favorable direction (the one showing higher resistance to deterioration processes). The potential bowing behavior of a commercial granitic rock must be examined prior to its use as a building element.

\section{Petromechanical properties}

\section{Uniaxial compressive strength (UCS)}

According to Mosch and Siegesmund (2007), uniaxial compressive strength (UCS) values in plutonic rocks vary from 60 to $292 \mathrm{MPa}$; the values for the gabbro-diorite subgroup are always in the upper quartile (Fig. 13c). In 
Fig. 16 Block sizes of the different quarries analyzed using three different methods Singewald (1992), Palmstrøm (1982, 1996, 2001), and Sousa (2010)

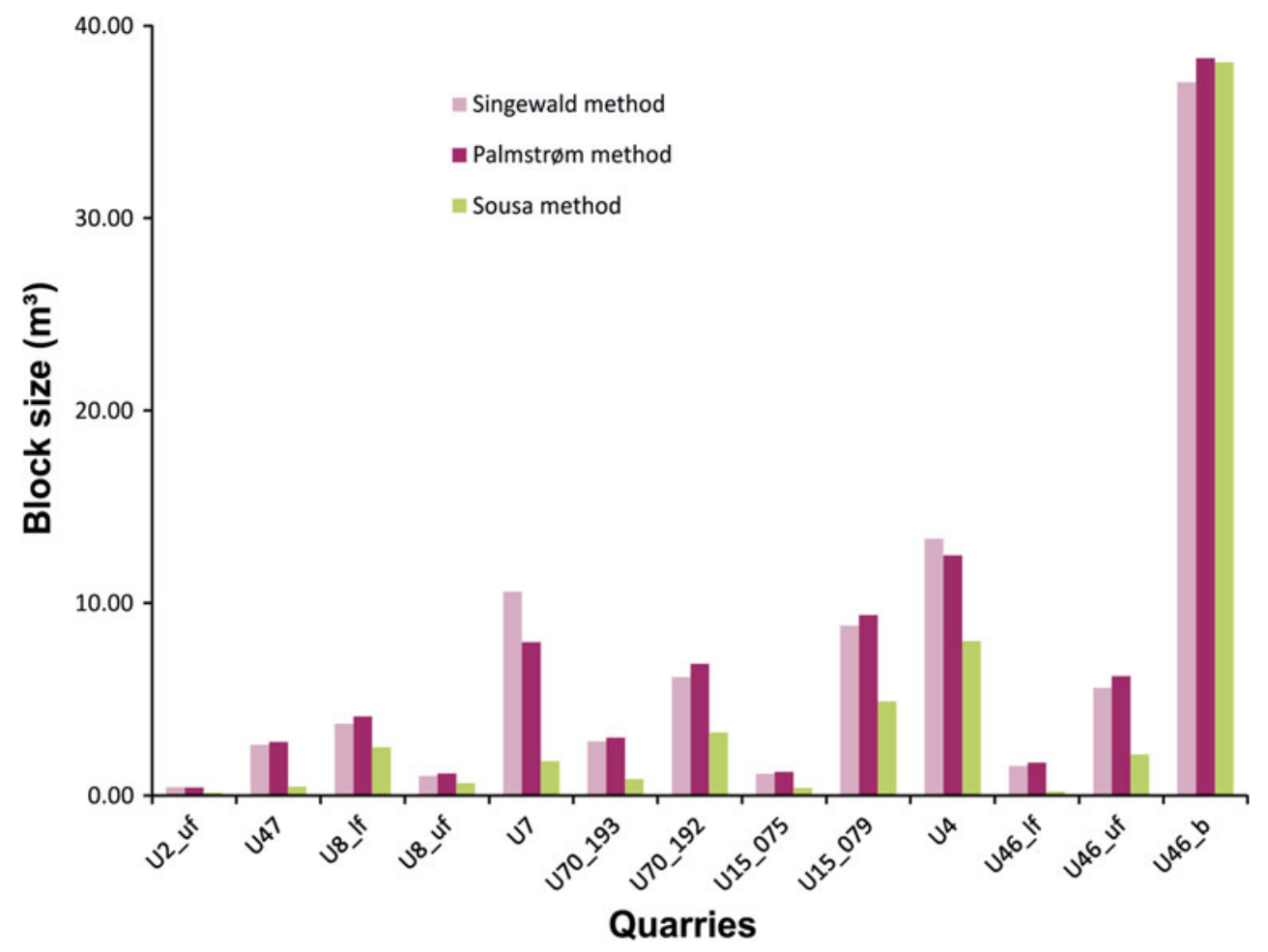

Uruguayan commercial granites, whose UCS was determined following the DIN EN 12372 (1999), the same behavior can be observed (Table A.3; Fig. 13c). Absolute Black Dolerite shows an extremely high value of $369 \mathrm{MPa}$, whereas the mafic rock with the lower UCS value is the Arapey Basalt with $228 \mathrm{MPa}$. The granitoids belong to the granite and granodiorite-tonalite groups determined by Mosch (2008). They show higher UCS values than the median for both groups, for some granite this value is higher than the upper quartile (197 MPa for Cuchilla del Perdido and Cerro Áspero Granites). The syenitoids (monzonite-syenite group of Mosch 2008) also show higher or similar values that the median for this group, with the exception of the Artigas Pearl Syenite that has an UCS value lower than the lower quartile (137 MPa).

The only rock analyzed showing a distinct rock fabric and a stretching lineation is the Maldonado Granite (Oyhantçabal 2005). However, this rock also shows no anisotropy in the compressive strength.

\section{Young's modulus}

The maximum Young's modulus $E$ value is $32.9 \mathrm{GPa}$ for the Absolute Black Dolerite in the $x$-direction and in the $y$ direction for the Chamangá Gray Granodiorite (Table A.3). The Cuchilla del Perdido Granite shows the lowest value: 11.9 $\mathrm{GPa}$ in the $z$-direction. A general trend, similar to that described by Hoffmann (2006), can be observed in the relationship of the Young's Modulus $E$ and the UCS. The samples that have the higher UCS also have the higher Young's Modulus E.

\section{Indirect tensile strength}

The indirect tensile strength values for all commercial granites considered are lower than the lower quartile determined by Mosch (2008) and most of the values are outliers in the normal statistical distribution (Fig. 13e). The higher values are those of the mafic rocks, where the dolerite Absolute Black has the highest value (17.9 MPa), followed by Moderate Black and Pimafox dolerites, with 15.6 and 14.5 MPa, respectively. Artigas Pearl Syenite shows the lowest value (5.8 MPa), followed by Moskart granite (7.7 MPa) (Table A.3).

\section{Flexural strength}

Comparing the flexural strength values, determined according to the DIN EN 12372 (1999), with those of Mosch (2008) (Fig. 13d), it can be seen that the dolerites lie far above the highest values, being outliers in the distribution determined by the aforementioned author. The granitoid groups show values that are either higher than the upper quartile (Cuchilla del Perdido and Maldonado granites, with 20.2 and $20.4 \mathrm{MPa}$, respectively) or lower than the lower quartile (Moskart Granite, with 8.3 $\mathrm{MPa}$ ) (Table A.4). Chamangá Granodiorite shows a flexural strength that is higher than the upper quartile (20.4 MPa). 




The syenitoid group shows very different values. Salmon Red is in the upper quartile (15.6 MPa), the Violeta Imperial value is lower than the lower quartile (10.0 MPa), and Artigas Pearl is 8.3 MPa.

\section{Breaking load at dowel hole}

Values obtained for breaking load at the dowel hole (DIN EN 13364 2002) vary between $1.8 \mathrm{kN}$ (Moskart Granite) and $4.7 \mathrm{kN}$ (Absolute Black Dolerite) (Table A.4). Mafic rocks show the highest values, followed by the granitoids with the exception of Moskart Granite and then the syenitoids, with the lowest values, in particular Artigas Pearl Syenite with $1.9 \mathrm{kN}$. Due to its fabric anisotropy, the Maldonado Granite was tested in three different directions according to the standard procedure. It shows a variation between 2.8 (Type IIa, dowels parallel to foliation) and 3.5 $\mathrm{kN}$ (Type IIb, dowels perpendicular to foliation). According to the data of Rohowski (2001), mafic rocks can be compared with mafic volcanics and tephrite (basalt lava) with breaking load values around $4 \mathrm{kN}$. The granitoids and syenitoids can be compared with the granite and gneiss of Rohowski (2001), with values around $3 \mathrm{kN}$.

A slab with a thickness of $30 \mathrm{~mm}$ composed of coarsegrained or very coarse-grained granitoids or in particular syenitoids, can eventually be represented by only two or three crystal grains. This kind of slab can thus have a limited strength (flexural, indirect tensile and compressive strengths, and breaking load at the dowel hole) and durability.

\section{Abrasion strength}

The abrasion strength was determined as described in the DIN 52108 (1988). The lower values of abrasion strength show the higher resistance of the rock to abrasion, therefore the rock most resistant to abrasion is the Pimafox Dolerite, with a value of $2.1 \mathrm{~cm}^{3} / 50 \mathrm{~cm}^{2}$ (Table A.4). The less resistant rock is Arapey Basalt, with a value of $3.8 \mathrm{~cm}^{3} /$ $50 \mathrm{~cm}^{2}$. All Uruguayan commercial granites have lower values than those discussed in the literature (Peschel 1977; Strohmeyer 2003; Siegesmund and Dürrast 2011).

The difference in the mechanical strength values observed between the various rocks considered can be explained by the fact that they differ in their mineralogical composition and fabric (Strohmeyer 2003). The mafic rocks show the highest strength values and this is related to specific characteristics of their fabric that make them more resistant: a fine- to mediumgrain size, subophitic texture, and in the case of the dolerites the graphic intergrowth that seals the interstitial spaces between the crystals making the rock very cohesive. This is well illustrated when comparing the UCS and flexural strength values with the bulk density and porosity (Fig. 14). 
Fig. 17 Stereograms (equal area projection, lower hemisphere) showing the measured joints using Stereo Net a Arapey Basalt from the Cerro del Estado quarry (contours 1, 2, 3, 4, 5 times uniform distribution: t.u.d.); b Cerro Áspero Granite quarries (contours 1, 2, 3, 4, 5, 6 times uniform distribution);

c Sacramento Dolerite from the Rosarito quarry (contours 1, 2 , $3,4,5,6,7,8,9,10$ t.u.d.); d Moskart Granite (contours 1, 2, 3, 4, 5 t.u.d.); e Artigas

Syenite (contours 1, 2, 3, 4, 5, 6,

7 t.u.d.); and f Violeta Imperial (contours 1, 2, 3, 4, 5 t.u.d.)
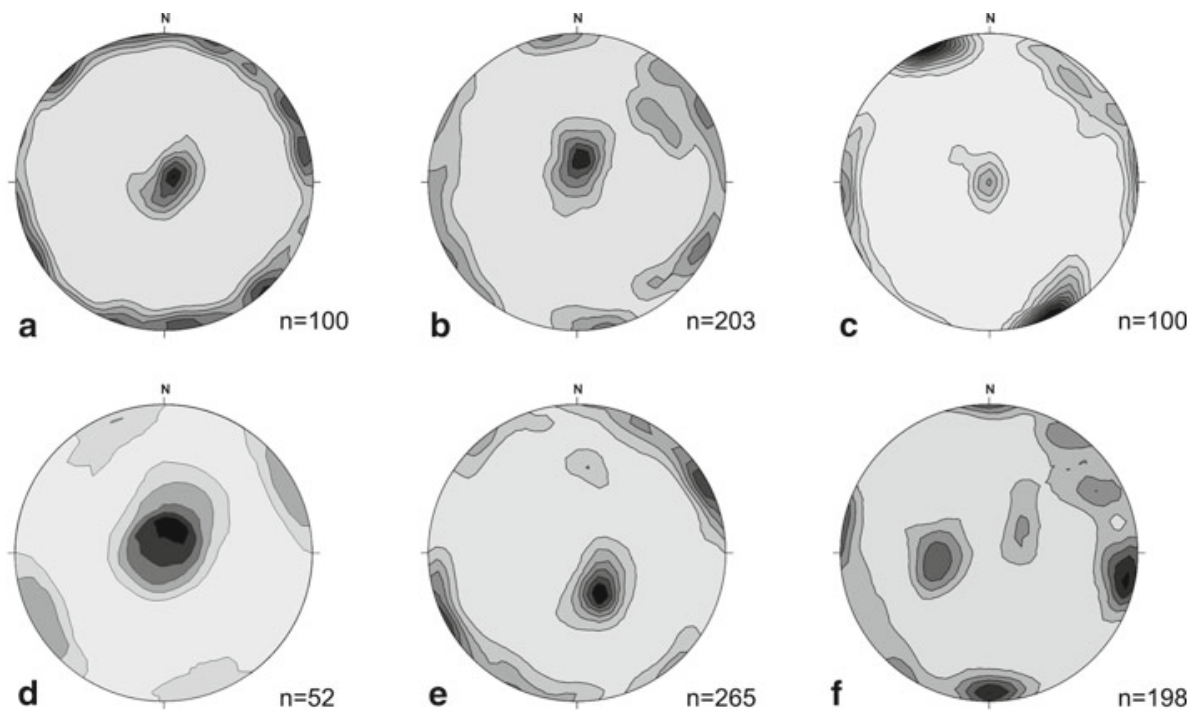

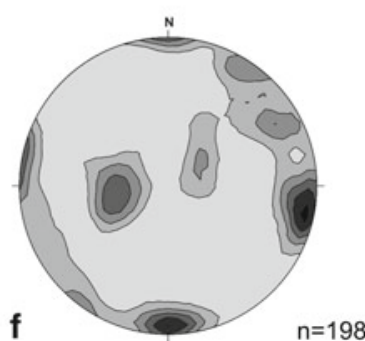

Generally, the very coarse-grained rocks show the lowest strength values; this is the case in the Moskart Granite and Artigas Pearl Syenite. This is probably related to the presence of microcracks and the cleavage of the large alkali feldspar present in these rocks. The strength of a rock can also be correlated with the apparent density and effective porosity: the higher density of a rock and the lower its porosity determines higher strength values (Morales Demarco et al. 2007; Mosch 2008). This correlation can be observed in all commercial granites considered in the present study (Fig. 14).

\section{Deposit characterization}

The evaluation of the mineral deposit was carried out following the International Framework Classification of the United Nations/UNFCR (UN 2009). The classification is based on three categories: (i) degree of favorability of social and economic conditions (e.g., market prices, relevant legal, and environmental conditions) ( $E$-axis); (ii) maturity of studies and commitments to implement mining plans that determine the feasibility of the mining project ( $F$-axis); and (iii) level of confidence in the geological knowledge and potential recoverability of the quantities (the $G$-axis). Commercial projects are the ones feasible from a technical, economic, and social point of view. Dimensional stone deposits are not representative of typical mineral deposits as for example massive mineral deposits (construction aggregates, e.g., sand, gravel). The industrial requirements in décor and block volume (or size, or dimensions) determine the selection of a section inside a deposit, in which these requirements are achieved and are at the same time demanded by the market (Stein 2007). Basically, some aspects of the evaluation of aggregate deposits can be applied in the case of dimensional stones (Kelter et al. 1999). An example is the application of mining techniques (e.g., diamond wire saw) that have proved to be effective in comparable dimensional stone deposits.

The geological and mining knowledge of the analyzed deposits exhibits a highly differentiated state of the art. This ranges from a general assignment of a lithological unit $(\mathrm{Cu}-$ chilla del Perdido Granite) to many years of geological investigations in active mining districts (dolerite deposits, e.g., Moderate Black Dolerite U8, U11O, U66). Both the growth of the international market for dimensional stone and the industrial development in the production requires more intensive research into the feasibility of mining the deposits:

(1) The selection of the décor, especially the color is determined by international trends, which are not constant. Some trends are cyclical for decades, but others are acyclical. Rocks with colors outside of the prevailing trend are temporarily or only partially usable (e.g., the pink facies of Artigas Pearl Syenite).

(2) The dimensional stone raw blocks are processed mainly in industrial plants. For this purpose the blocks must have, on one hand, an orthogonal form (Fig. 15) and a minimum size, and on the other hand the choice of the block size is often related to the optimal utilization of the resource related to the size of the end product (e.g., block size between 3.5 and $9 \mathrm{~m}^{3}$ ).

(3) Due to modern requirements for the use and construction of buildings, rocks with the same color and décor will be chosen for a technical function in accordance to their maximum resistance of a selected property (e.g., rocks with high abrasion resistance as floor slabs).

The effects of the above-mentioned international market mechanisms were directly decisive for the development of the natural stone industry in Uruguay in the last 20 years. 
Fig. 18 Rosarito dolerite quarry a general view of the upper and lower floor; $\mathbf{b}$ joint set frequency of the upper floor; c joint set frequency of the lower floor; $\mathbf{d}$ median block volume of the upper floor; and e median block volume of the lower floor

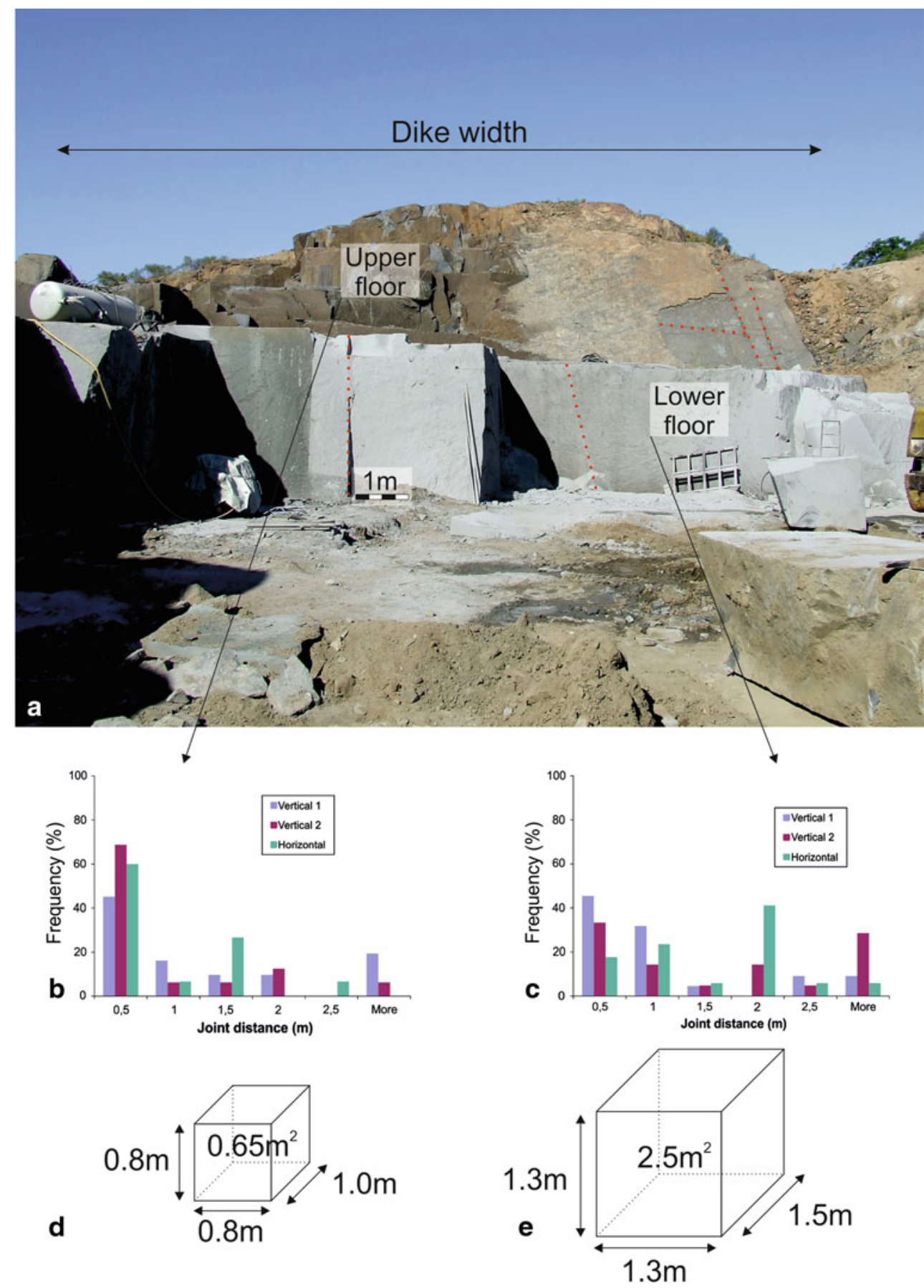

Because of its natural conditions (climate), the country could not follow the international trend toward yellow dimensional stones in the years 1995-2006. This particular color is due to limonitic alteration of the rocks (a characteristic of tropical countries), which, nevertheless, retain their essential petrophysical properties. The rocks offered did not fulfill the international trend and their business volume significantly declined. Only the timeless décor and color offered by the dark gray to black dolerites occupy a permanent place on the international market. Even this segment needs qualitative development to be able to compete with the blocks offered from Northern China and India exhibiting larger dimensions.

The criteria for deposit profitability require geologic studies that can determine the following controlling elements:

(1) An inventory of the joint sets to determine the frequency of minimum dimension of exploitable blocks to achieve the optimal block size for the industry, as well as to minimize the waste material. 
Fig. 19 3D model of the Maldonado Granite made using 3D Block Expert a section of the quarry modeled (total volume $191 \mathrm{~m}^{3}$ ), some joints are marked in red, $y z$-plane is the foliation plane, scale in meters; $\mathbf{b}, \mathbf{c} 3 \mathrm{D}$ view of the section modeled; $\mathbf{d}$ stereogram of the Maldonado quarry with walls of section modeled in blue $(x)$ and green $(y)$; e joint frequency histogram of the quarry; and $\mathbf{f}$ raw block volume distribution using 3D Block Expert

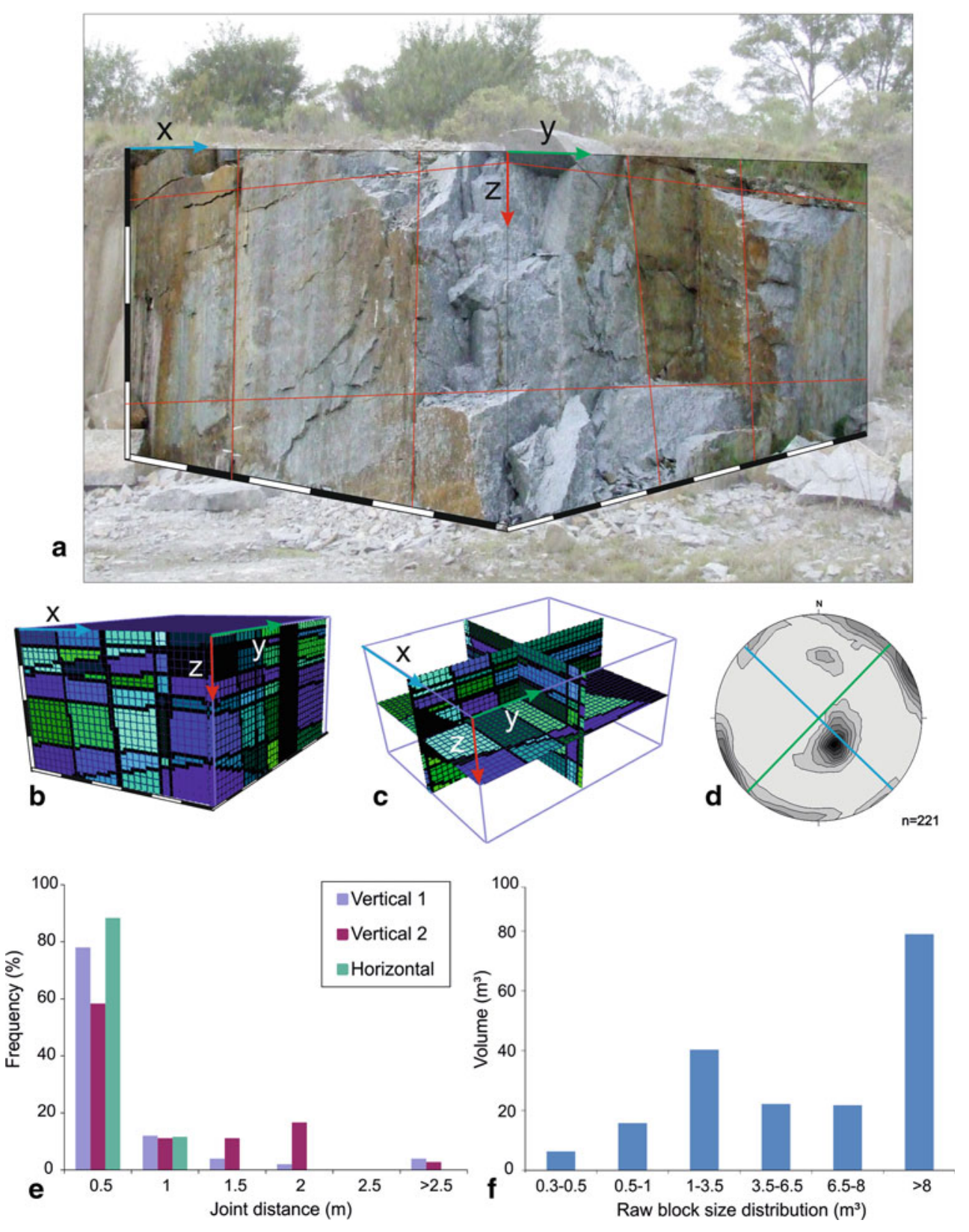

(2) Mineralogical and structural factors that influence the formation, stability, and variability of the fabric and color.

(3) Factors of the genesis of the deposit, as well as the influence of alteration, which causes an impact on the relevant petrophysical properties, that favor or limit the usability.

\section{Block sizes}

For the evaluation of the yield of a quarry, the block sizes must be estimated. This can be done as described by
Singewald (1992), Palmstrøm (1982, 1996, 2001), and Sousa (2010). All these authors use the joint set frequency to estimate the mean or median block sizes. Singewald (1992) method is the less complex to use, since it calculates $\mathrm{Vb}$ (block volume) by multiplying the average distribution of three main joint sets (See Eq. 1). Palmstrøm (1982, 1996, 2001) uses the Jv (volumetric joint count) (See Eq. 2) and $\beta$ (block shape factor; Eq. 3) for calculating $\mathrm{Vb}$ (See Eq. 4). Sousa (2010) uses Jmed (median volumetric joint count) (See Eq. 5); the block volume was calculated afterward using (Eq. 4). The parameters $x, y, z$ and S1, S2, $\mathrm{S} 3$ are the distances between the different joints that 
Fig. 20 3D model of the Salmon Red Syenite made using 3D Block Expert a section of the quarry modeled (total volume $396 \mathrm{~m}^{3}$ ) with some of the joints marked in red, scale in meters; $\mathbf{b}, \mathbf{c} 3 \mathrm{D}$ view of the section modeled; d stereogram of the Maldonado quarry with walls of section modeled in blue $(x)$ and green (y); e joint frequency histogram of the quarry; and f raw block volume distribution using 3D Block Expert
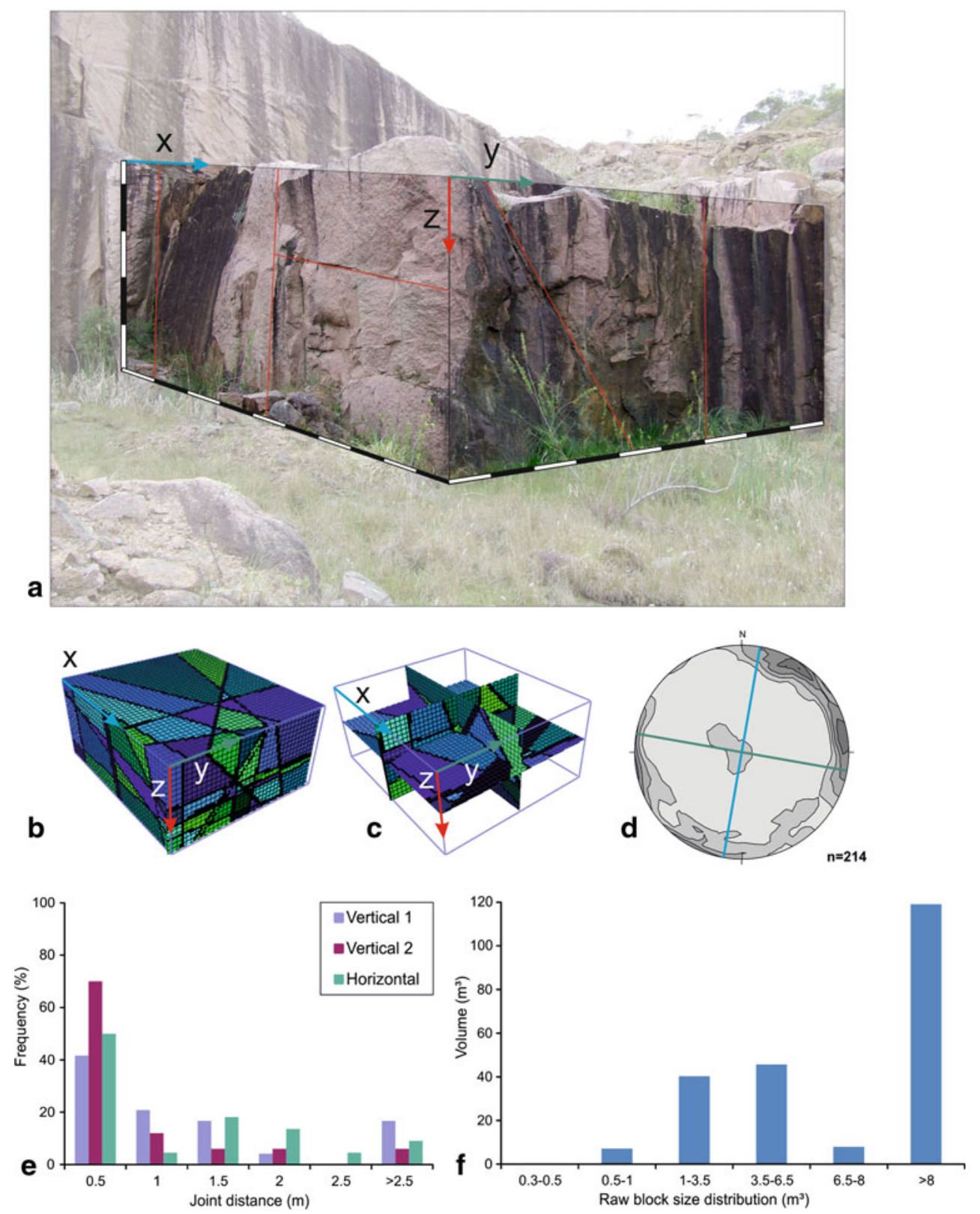

compose a joint set, and $\alpha 1, \alpha 2$, and $\alpha 3$ the angles between these joint sets.

$V_{\text {average }}=x_{\text {average }} * y_{\text {average }} * z_{\text {average }}$

$\mathrm{Jv}=1 / \mathrm{S} 1+1 / \mathrm{S} 2+1 / \mathrm{S} 3$

$\beta=(\alpha 2+\alpha 2 * \alpha 3+\alpha 3)^{3} /(\alpha 2 * \alpha 3)^{2}$

$\mathrm{Vb}=\beta * \mathrm{Jv}-3 * 1 / \operatorname{Sin} \alpha 1 * \operatorname{Sin} \alpha 2 * \operatorname{Sin} \alpha 3$

Jmed $=1 / \mathrm{S} 1$ med $+1 / \mathrm{S} 2$ med $+1 / \mathrm{S} 3$ med

The three methods were applied in several Uruguayan quarries and different block sizes were obtained (Table 5; Fig. 16). Table 6 shows that the Sousa (2010) is the most conservative estimation, since it uses the median and not the average joint spacing as the other methods. For all the cases analyzed the joints were measured and afterward their spacing, taking into account to which joint set they belong. The orientations of the joints are shown in the stereograms in Fig. 17.

When possible, the joint sets as well as their spacing in more than one floor were measured. In the case of the Artigas Pearl syenite quarry, the boulder zone at the top of the deposit was also measured (U46_b). The sizes of these boulders are greater than the average and median blocks calculated using the equations above for the floors in the quarry itself (Table 6). In the case of the Rosarito dolerite quarry, block sizes in the lower floor are higher than in the upper floor, since the joint density is also higher in the upper floor (Fig. 18). 
a
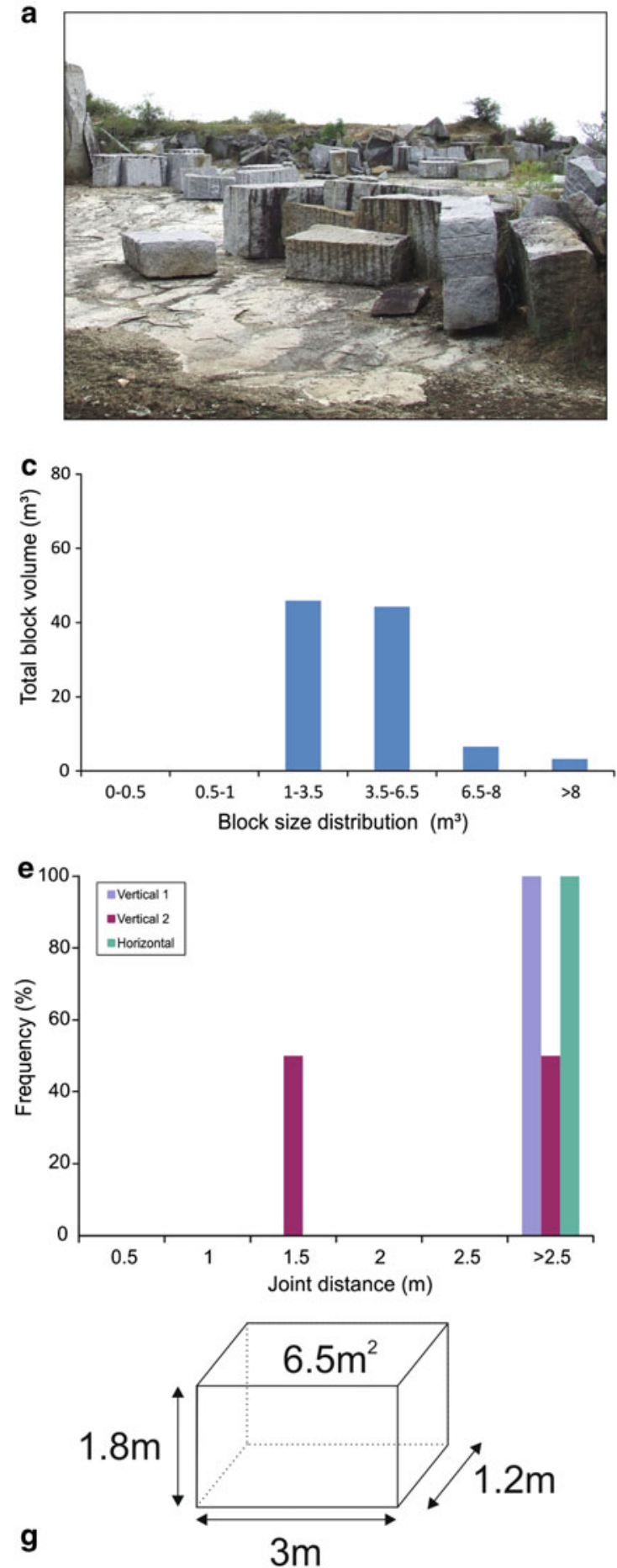

b
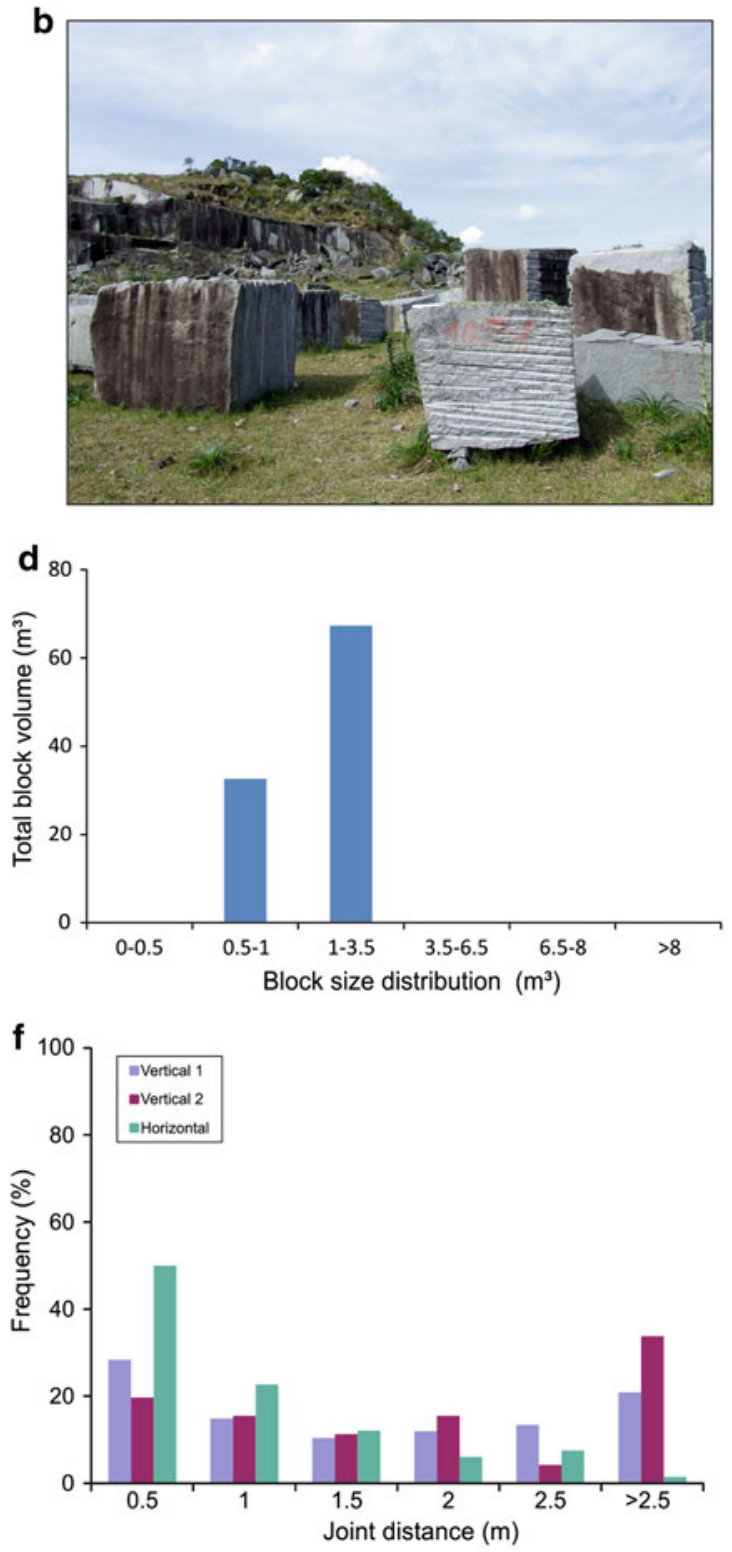

h

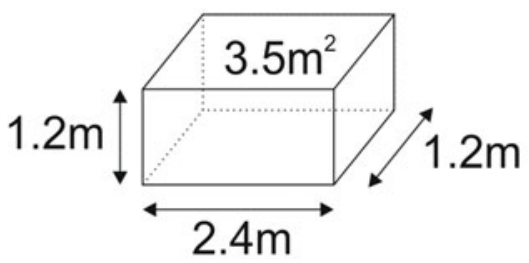

Fig. 21 a, c, e, g Cufré Granite quarry; b, d, f, h Cerro Áspero Granite quarry number 192. a, b Block deposit; c, d Block sizes measured directly in the quarries; $\mathbf{e}, \mathbf{f}$ joint set distribution; and $\mathbf{g}, \mathbf{h}$ Plausible block sizes being obtained in the quarries studied

In the Maldonado Granite and especially in the Artigas Syenite the opposite occurs. A possible explanation for this abnormal behavior can be found in the two-stage landform development model proposed by Büdel (1957) and described by Twidale (2002). In the first stage, surface rock is affected by the weathering of the materials around the joints, and boulders start to form. Weathering then proceeds downwards into the subsurface, where the meteoric water stays longer in contact with the rock. In the second stage, the regolith between the joints of the surface is transported, but not with the regolith of the subsurface. Weathering can proceed more intensely in the subsurface since water is available. 


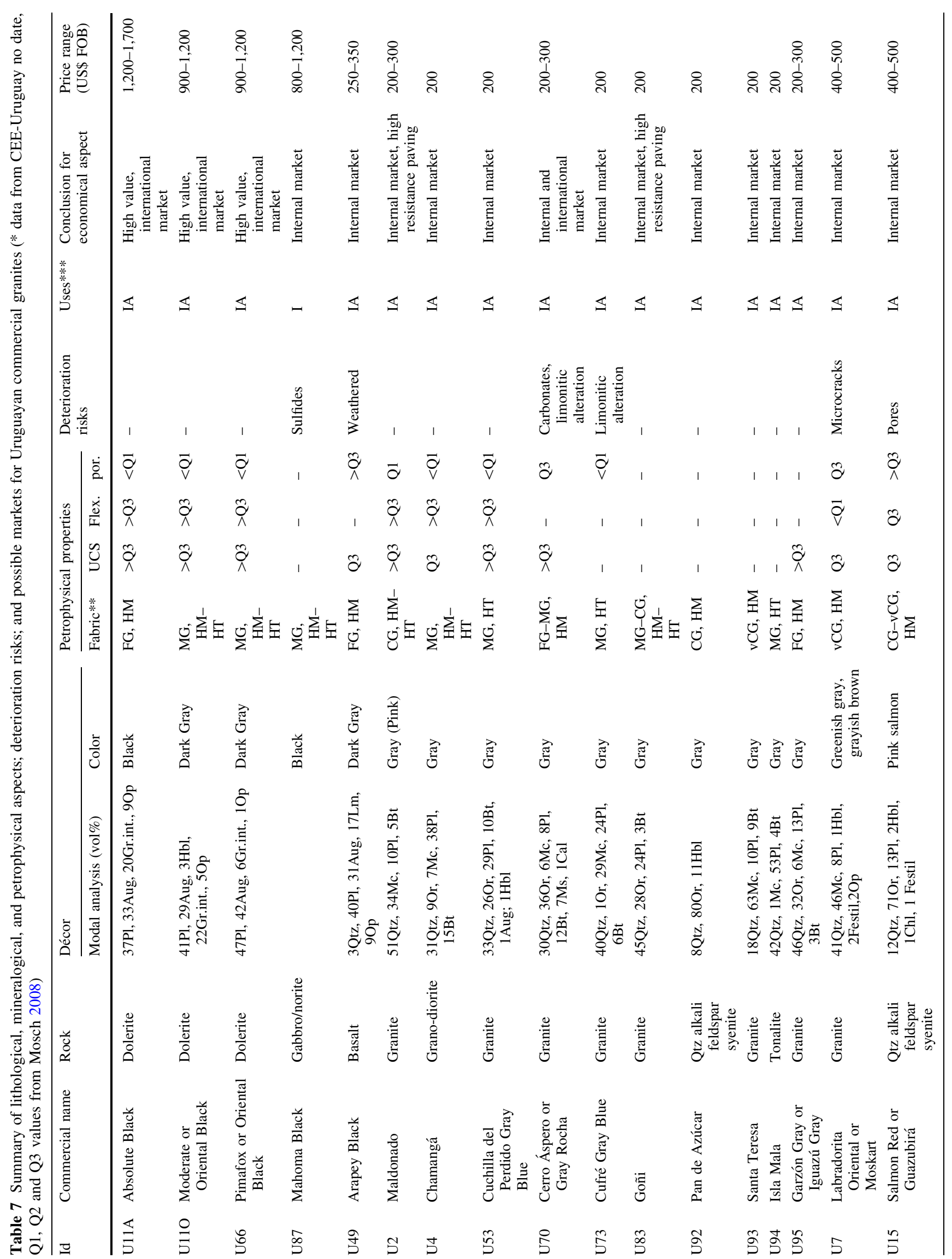




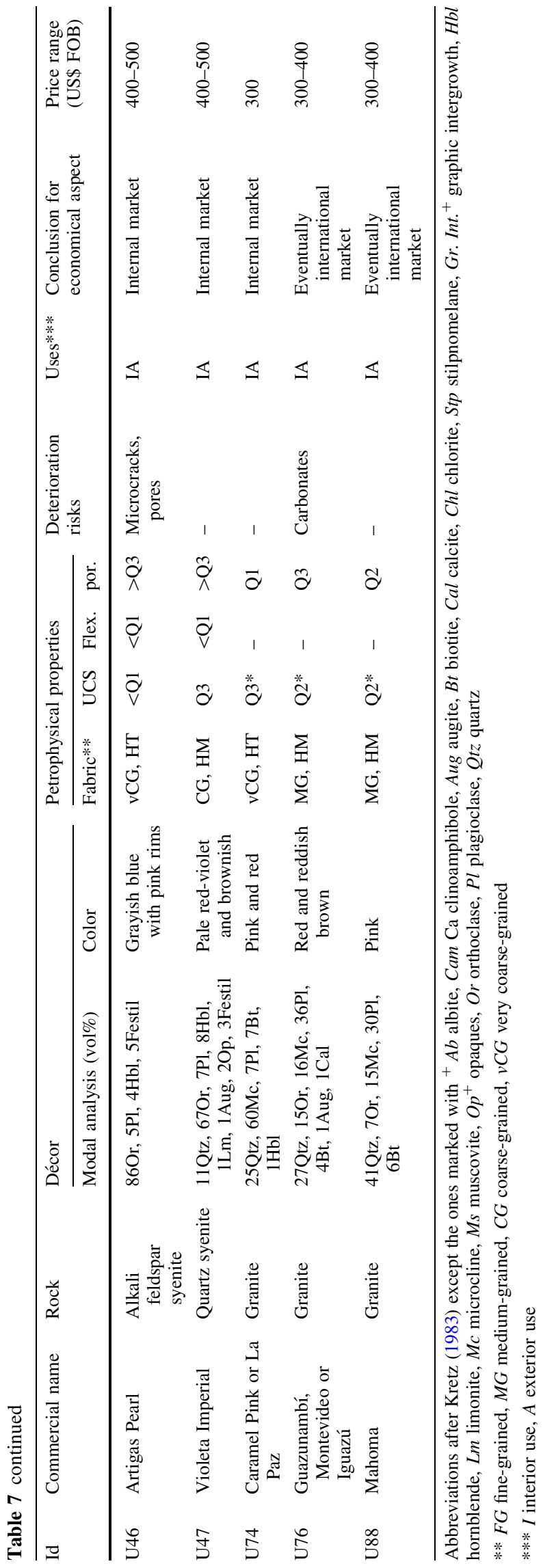

This results in a boulder zone at the top and a weathered zone underneath, whose thickness depends on the intensity and duration of weathering. For dimensional granitic deposits it is important to determine the depth at which this weathering effect ends.

Another estimation method for block sizes uses the software 3D-Block Expert described in Nikolayew et al. (2007), Siegesmund et al. (2007a, b), and Mosch et al. (2010). This program provides a better spatial distribution of the blocks in the section of the quarry considered for an optimized extraction. Sections of three quarries were modeled using this program: the Maldonado Granite (Fig. 19), Cufré Granite, and the Salmon Red Syenite (Fig. 20). In the Cufré Granite the whole quarry was modeled (a total volume of $9,979 \mathrm{~m}^{3}$ ), but the total amount of joints measured was very low (seven). The quarry is most likely not very representative of the global behavior of the deposit, and therefore, the results of the tectonic analyses overestimates the block sizes obtained by real mining.

In the Maldonado Granite model (Fig. 19a-c) two subvertical joint sets are observable, which are orthogonal to each other, and a third joint set that is subhorizontal with a significant dip (Fig. 19d, e). This last joint set affects the deposit negatively, since it diagonally crosscuts the blocks that would otherwise be regular. The joint set parallel to the yz-wall is determined by the foliation of the rock, as depicted in Fig. 19a. The raw block size distribution (Fig. 19f) shows that the highest proportion of raw blocks is larger than $8 \mathrm{~m}^{3}$.

The Salmon Red Syenite model (Fig. 20a-c) shows a lower amount of joints affecting the considered section. However, there are four joint sets affecting the rock and this is evidenced by the presence of vertical joints that are not orthogonal (Fig. 20d, e). The raw block distribution shows that most of the blocks that this section is able to produce are between 3.5 and $6.5 \mathrm{~m}^{3}$ and larger than $8 \mathrm{~m}^{3}$ (Fig. 20f).

In two inactive quarries it was possible to measure the blocks remaining after the commercialization of the best ones. These are probably not the largest blocks that those quarries once produced (Fig. 21a, b). Most of the blocks in the Cufré Gray Blue quarry number 172 have a volume between 1 and $6.5 \mathrm{~m}^{3}$ (Fig. 21c) being larger than those in the Cerro Áspero quarry (Fig. 21d). This is in accordance with the joint set frequency measured for both quarries (Fig. 21e, f) and the results acquired by applying the method of Singewald (1992), Palmstrøm (1982, 1996, 2001), and Sousa (2010) (Table 6; Fig. 16). The application of these methods in the Cufré quarry leads to a block size that is extremely large, but in accordance with those sizes obtained using the program 3D Block Expert. 
Reserves and economic aspects

The feasibility of the utilization of a deposit is determined not just by the dimensions of the deposit, but also by the economic demands and the deposit geometry, the stability of the country rock and the environmental conditions (clima, infrastructure, etc.). Nevertheless, the decisive criterion is the volume of the deposit. This depends on the dimensions of occurrence of the rock, which actually meets the criteria of a marketable color and décor with exploitable block sizes. In the present research the surface area has been determined by the analysis of geological maps, satellite images, and observations in the field. A careful analysis of the morphology of the area of the deposit can lead to the identification of sectors not suitable for mining (e.g., occurrence of faults or highly fractured sectors).

For the calculation of maximal reserves, it is reasonable to assume a maximum depth of $100 \mathrm{~m}$. The reasons for not considering a greater depth are the stability of the rock massif, the economic costs of mining (e.g., transport costs, cost of water pumping, mine ventilation, safety of the staff, etc.), and rock mechanical problems (stress relief at greater depth can lead to intense fracturing, limiting the production of blocks). In stratiform deposits only the maximum depth of the strata is exploitable.

The exploration and evaluation of a dimensional stone deposit should consider, on the one hand, the maximum extension of the reserve. On the other hand, a minimum deposit volume is required. The opening and operation of a quarry demands a significant investment that is commonly covered by loans. The repayment period is between 10 years for movable goods and 30 years for immovable properties. For dimensional stones a 30-year repayment period is also normally accepted. The main reason is that this kind of resource is not only listed on the stock exchange and their commercialization allows relatively low profit margins, but also due to its dependence on the prevailing taste (color and décor trends) and the trade cycles of the construction industry. In many countries the approval of operating plans for a quarry is based on these terms of repayment. For these reasons a minimum reserve volume should be calculated for a 30-year operation:

(a) Scheduled annual production volume, taking into account non-productive periods (rainy seasons, freezing temperatures, impassable transportation routes, work regime).

(b) Mining rate related to the joint systems inventory of the deposit.

(c) Mining rate by squaring of the industrial blocks.

(d) Mining rate considering the influence of lithological elements, which require a differentiation by taking into account the quality of the color and décor, which causes an impact on the revenue.

(e) In addition, the rate of utilizable raw material for the fabrication of products that are not taken into account in the industrial usable blocks (e.g., small blocks for self-production, building bricks, paving materials).

\section{Mafic rocks}

The mafic rock deposits provide one of the most important varieties of dimensional stone: the black commercial granite. In Uruguay they are mainly represented by the dolerite dike swarm, which intrudes into an area covering $20,000 \mathrm{~km}^{2}$ in the southwestern part of the country.

The dikes are normally not wider than $40 \mathrm{~m}$ and around one kilometer long. The maximal depth reached in the quarries by the prevailing mining method is about eight meters. In similar deposits in northern China and southern Sweden depths of more than $50 \mathrm{~m}$ are possible.

In these kinds of deposits the maximum mineable depth is a very relevant factor for the economic viability of the mine. The stability of the country rock is an important parameter to consider when the mining proceeds downwards. When the country rock is not stable enough, the mining can lead to landslides compromising the safety of the personnel (staff) and the continuity of the mining itself. This holds especially true in the case of the Uruguayan dolerite deposits, where the contacts of the dikes with the country rock are sub-vertical and dipping steeply to the southeast (Morales Demarco et al. 2011). The waste rock produced in the mining of the dolerites is usually higher than that of other commercial granites with a different geometry.

In several dikes from Group A (high $\mathrm{TiO}_{2}$ ) a variation of the grain size is observable from the contact with the country rocks (where the grain size is finer) to the center of the intrusion (where the grain size is coarser). Thus, two varieties of commercial granites can be mined: one is a very fine-grained and deep black color (Absolute Black) and another is dark gray in color (Moderate Black) (Morales Demarco et al. 2011). Based on a minimum of 19 identified productive dikes in the dike swarm outcrop area $\left(20,000 \mathrm{~m}^{2}\right)$, these authors proposed a probable reserve of $407,500 \mathrm{~m}^{3}$, being $10 \%$ of Absolute Black quality.

Economic aspects of mafic rock deposits

Due to their high quality color, décor, and petrophysical properties these rocks are very valuable. They have international prices between 1,200 and $1,700 \mathrm{US} \$ / \mathrm{m}^{3}$ free on board (FOB) for the Absolute Black and between 900 and $1,200 \mathrm{US} \$ / \mathrm{m}^{3}$ FOB for the Moderate Black (Table 7). 
For Moderate Black a probable reserve of $366,750 \mathrm{~m}^{3}$ is proposed (Morales Demarco et al. 2011). Taking an average value of $1,000 \mathrm{US} \$ / \mathrm{m}^{3}$ FOB an annual production value of 12.2 million US\$ of Moderate Black can be calculated for a 30 -year mining period. Absolute Black has a lower probable reserve of $40,750 \mathrm{~m}^{3}$ (Morales Demarco et al. 2011), but a higher price, of $1,500 \mathrm{US} \$ / \mathrm{m}^{3}$. For the same mining period would lead to a value of 2 million US\$/year.

\section{Gray Granitoids}

The Uruguayan granitoids only show a small variety of the typical colors and décors of the internationally marketed granitoids. Most of the granitoids mined in the country are gray and medium-grained. This kind of hard dimensional stone is widespread worldwide and their décor is not so interesting for the international market. Nevertheless, three of them are interesting for the local and regional markets: Cufré, Maldonado, and Cerro Áspero. The last one is possibly the most relevant due to its fine-grained texture, light gray color, and excellent petrophysical properties.

\section{Cerro Áspero Granite}

The mining district Cerro Áspero Granite (U70) is located around $13 \mathrm{~km}$ west of the city of Rocha, in eastern Uruguay (Fig. 5). This district contains four quarries. Two of them are relatively large quarries (about 3,000 $\mathrm{m}^{2}$ ), which are presently inactive and the other two are still active but smaller (around $400 \mathrm{~m}^{2}$ ).

The rock is a fine- to medium-grained light gray granite with a relatively scarce occurrence of enclaves or veins. Its color and décor are very interesting for the international market, and since this rock has very good petrophysical qualities, it could compete for a place in the fine-grained gray granites sector.

The quarries are located in a granitic massif occupying an area of approximately $1.8 \mathrm{~km}^{2}$, which is expressed in the geomorphology as a gentle slope $(1.5 \%)$ hill, known as Cerro Áspero. The rock mined is characterized by a slight differentiation in grain size between fine- and mediumgrained and a light gray color. Phenocrysts of plagioclase of white and light gray colors (up to $10 \mathrm{~mm}$ ) and black clots of biotite (up to $5 \mathrm{~mm}$ ) can eventually appear. Small mafic enclaves (up to $3 \mathrm{~cm}$ ) and narrow aplitic dikes (up to $1 \mathrm{~cm}$ ) are relatively rare. The décor and color of this granite is very homogeneous.

A boulder zone occurs at the top of the hill, with potential interest for the squaring of large blocks. There the yield of production is expected to be very high (around $90 \%$ ). The underlying weathered zone is around two meters thick in the already opened quarries. This zone represents waste material for the dimensional stone industry, but it could be used for road paving and quarry filling after the mining ceases, thus reducing the cost of mining.

The most economically interesting sector is on the eastern side of this granitic massif, where one of the large inactive quarries is located (quarry number 192). The factors that make this sector more interesting are the fine grain size of the rock and the more favorable joint set distribution.

The distribution of the fine-grained area is around $90,000 \mathrm{~m}^{2}$. A minimum depth of $10 \mathrm{~m}$ can be easily reached taking into account the mining situation in the deposit. The gentle slope of the hill where the deposit is localized allows the consideration of the surface as flat to simplify the calculations. This assumption is valid for all the following deposits considered. The raw production of this sector would be around 0.9 million $\mathrm{m}^{3}$. The yield of production inferred is $50 \%$ taking into account the blocks in the deposit and the waste material produced: $450,000 \mathrm{~m}^{3}$. The block size determined using the Singewald (1992), Palmstrøm (1982, 1996, 2001) and Sousa (2010) methods are 6.16 and $3.27 \mathrm{~m}^{3}$, the maximum and median, respectively. The sizes of the blocks in the deposit were measured (Fig. 18b, d) and they are smaller than those calculated using the cited methods. This is because they are the blocks left behind after the commercialization of the better ones, probably due to their inferior quality or smaller size.

Quarry number 193, the second largest quarry, is also currently inactive and located in the western sector of the deposit. The rock is characterized by its medium-grained texture and by the relatively higher frequency of joints. From the joint set distribution measurements, a faultdamage zone presumably affects this quarry, since the block sizes calculated using the Palmstrøm (2001) and Sousa (2010) methods are significantly smaller than those obtained for quarry number 192 (Table 6). In fact, this quarry produces small paving stones (around $0.04 \mathrm{~m}^{3}$ ) using unsophisticated technology.

\section{Cufré Gray Blue Granite}

The Cufré Gray Blue Granite deposit is located $16 \mathrm{~km}$ from Nueva Helvecia, in the Colonia department. The only quarry in the area is now inactive. The rock is a mediumgrained gray granite with relatively frequent mafic enclaves and narrow aplitic dikes and a gentle foliation.

The previously described methods of Palmstrøm (1982, 1996, 2001) and Sousa (2010) probably overestimate the plausible block sizes being mined in this deposit. This is due to the lack of visible joints affecting the rock massif in the observed quarry. Nevertheless, taking into account the real block size distribution measured in the blocks left out in the quarry, it is possible to assume a production of large blocks suitable for processing by gang saw blade. 
The total outcrop area is around $15 \mathrm{~km}^{2}$, but the potentially most interesting zone is about eight hectares $\left(80,000 \mathrm{~m}^{2}\right)$, where the quarry was opened. The weathered zone is relatively narrow, around $1-1.5 \mathrm{~m}$ that has to be considered waste material in the cost calculation. A minimum mining depth of $10 \mathrm{~m}$ would lead to a total volume available for extraction of approximately $800,000 \mathrm{~m}^{3}$. A yield of $30 \%$ is possible for this deposit taking into account the structural elements, such as mafic enclaves, dikes, and the low incidence of joints. From this $240,000 \mathrm{~m}^{3}$ to be produced, just around $10 \%$ will attain the requirements for exportable blocks.

\section{Maldonado Granite}

Maldonado district is located five kilometers from the cities of Maldonado and Punta del Este. There are three active quarries, whose production consists mainly of small blocks with rough surfaces for the local market.

The rock is characterized by a dark gray color and a coarse-grained and foliated fabric. In the upper floor of the quarry the evidence for weathering is visible by the oxidation of the biotite clots as limonitic (orange) spots. Elongated mafic enclaves and aplitic dikes are aligned within the foliation and so homogeneously distributed that they act as part of the décor.

The district area is about $1.3 \mathrm{~km}^{2}$ and $5 \%$ of it could be possibly mined. Considering a mining depth of $10 \mathrm{~m}$ at several levels, the total volume would be $650,000 \mathrm{~m}^{3}$. The normal yield for this kind of mining in Uruguay is around $30 \%$. Since the requirements for this rock are not high, there is no limitation in respect to block size. This is very relevant because, even though the raw block size distribution modeled using the software 3D Block Expert show positive results (Fig. 19), the block size calculations using the Palmstrøm (1982, 1996, 2001) and Sousa (2010) methods show very small block sizes $\left(<0.20 \mathrm{~m}^{3}\right)$ (Table 6$)$, making this rock incapable of entering international markets.

\section{Moskart Granite}

The Moskart Granite district is situated in the locality of Soca, about $50 \mathrm{~km}$ east of Montevideo. Several quarries were active in this district; however, at present there are no mining activities. These activities were in close connection with more traditional farming activities (e.g., agriculture and livestock).

This district has an area of about $800,000 \mathrm{~m}^{2}$, being $10 \%$, located in different sectors of the district and interesting for mining. For a reserve calculation a mining depth of $10 \mathrm{~m}$ can be considered, even though it is possible to reach larger depths due to the stability of the rock massif. The yield of this dimensional granite is considered to be high (about $50 \%$ ) allowing for the absence of waste material in the areas surrounding the quarries. A probable reserve of $400,000 \mathrm{~m}^{3}$ is calculated for the Moskart Granite deposit.

From the block size calculations relatively small block sizes are expected. The most conservative method (Sousa 2010) calculations determine a median block size of $1.8 \mathrm{~m}^{3}$.

Economic aspects of gray granitoid deposits

Gray granitoid deposits show a relatively narrow décor range and their petrophysical properties are very good. The prices for these granites range between 200 and 300 US\$/ $\mathrm{m}^{3}$ FOB (Table 7).

From the reserve calculations, the Cerro Áspero Granite deposit could produce annually up to $15,000 \mathrm{~m}^{3}$ of large-, medium-, and small-sized blocks. These blocks could be traded with prices of around 200-300 US\$, depending on their sizes, color, and décor quality. The annual quarry gross income would be between 3 and 4.5 million US\$.

For Cufré Gray Granite an annual production rate of $8,000 \mathrm{~m}^{3}$ is proposed. Considering an international price for this kind of dimensional stone of $200 \mathrm{US} \$ / \mathrm{m}^{3}$, the annual quarry gross income would be around 1.6 million US\$.

An annual rate of $6,500 \mathrm{~m}^{3}$ is estimated for Maldonado Gray Granite deposit. The annular income taking a price of $200 \mathrm{US} \$ / \mathrm{m}^{3}$ would be 1.3 million US\$.

The Moskart Granite is with no doubt the exception in this group, since its décor is very unique and it is possible to square large blocks making this rock very competitive. Its price is between 400 and $500 \mathrm{US} \$ / \mathrm{m}^{3}$ FOB (Table 7). The yearly production rate would be $13,000 \mathrm{~m}^{3}$. Considering that $10 \%$ of this production are exportable blocks and taking the price in $\mathrm{m}^{3}$ of $450 \mathrm{US} \$$, an exportation income of 585,000 US\$ should be expected.

\section{Syenitoids}

Uruguayan syenitoids are mined in two districts in the Sierra de las Ánimas Complex. Since the start of production at the beginning of the 20th century and before the economic crisis in Uruguay in 2002, the production took place in small quarries offering a diverse color spectrum. In the southern mining area (Pan de Azúcar-Piriápolis) large quarries were located in the Cerro Pan de Azúcar and Sierra de las Palmas hills with a capacity to provide material for export. During the 1980s and 1990s, mining activity was concentrated in small quarries in the northern mining district (the Camino del Amigo-Estancia Guazubirá). Nowadays all quarries are inactive.

The color and décor of the syenitoids are a major controlling parameter of the deposit. They are related to the amount and grain size of the feldspars, and the color development related to hydrothermal alteration. 
Artigas Pearl

This deposit shows hydrothermal alteration and comprises a total exposure of $4.6 \mathrm{~km}^{2}$. Considering the outcrop conditions and the geological findings, an area of $90,000 \mathrm{~m}^{2}$ can be mined. Due to the intrusion of dikes, a decrease of $30 \%$ in the possible reserve volume has to be considered. The presence of dikes (mainly quartz alkali feldspar trachyte) leads to a high rate of waste material.

The waste material of the weathered section on the top of the deposit is not included in this estimation. Individual boulders are exposed in this section and are of industrial value, as long as good petrophysical properties stay and are not affected by joints. However, the amount of the waste material to be removed in the weathered section below the boulder zone is calculated to be around $90 \%$.

The joint distance measured thus far within the outcrops of the deposit indicates a decrease of the joint distance with the depth (See Table 6). At what depth the rock (Artigas Pearl Syenite) is weathered and the joints opened, is still an uncertainty. Hence, only boulders at the top of the hill and in the upper floor can be mined at present. Average block sizes of 38.1 and $2.14 \mathrm{~m}^{3}$ (median) were determined for the boulder zone and upper floor, respectively. A new exploitation of this upper floor should be geared to the geometry of the surface. The mining rate of the boulder zone is estimated to be very high (around $50 \%$ ), being drastically lower in the upper floor by around $10 \%$. Considering that the boulder zone extends for an area of $240,000 \mathrm{~m}^{2}$ and the average height is $5 \mathrm{~m}$, the probable reserve of this zone taking into consideration the yield of the mining would be around $600,000 \mathrm{~m}^{3}$. The upper floor could be mined in a similar area and at similar depths, but as the yield is lower here a probable reserve of $120,000 \mathrm{~m}^{3}$ is expected.

\section{Pan de Azúcar White}

In the southern mining district white syenite crops out in the hill Cerro Pan de Azúcar. Commercially it is known as Pan de Azúcar White, but the quarry from where it was mined is now inactive. This dimensional stone is characterized by its light gray color and coarse-grained texture. Even though this rock shows feldspar substitutions, the absence of red stain is related to the lack of hematite in the pores of the feldspar, probably due to the lack of hydrothermal influence.

The surface distribution of this deposit is unknown, due to the steep slope of the hill and the lush vegetation that covers the outcrops. A minimum area of $21,000 \mathrm{~m}^{2}$ is determined by the extent of the inactive quarry and its surroundings. Considering a safe mining depth of $10 \mathrm{~m}$, the probable reserves would be about $210,000 \mathrm{~m}^{2}$. With a mining yield of $50 \%$, a block production of $105,000 \mathrm{~m}^{3}$ is expected.
Guazubirá Syenites: Salmon Red and Violeta Imperial

In the northern mining district the pink and light red colors dominate (Salmon Red Syenite). The mining district has an area of about $5 \mathrm{~km}^{2}$. Typical for this district are numerous wide fault zones as indicated by the valleys. Former mining in the center or nearby these zones produced only ballast and rubble (aggregates).

The joint set distribution has been measured and analyzed using the previously described methods of Palmstrøm (1982, 1996, 2001) and Sousa (2010). A deposit (quarry number 075) for production of dimensional stone localized in a fault zone has a median block size of just $0.4 \mathrm{~m}^{3}$. In another deposit (quarry number 079) outside the fault zones a median block volume of $4.89 \mathrm{~m}^{3}$ is calculated. Considering the tectonic setting the potential mining area is reduced to almost $30 \%$ of the whole deposit: $1.5 \mathrm{~km}^{2}$. The waste material would be considered a cost factor, but not as a decrease in the reserves.

For a realistic calculation of the deposit reserves, quarry 079 will be used as an example. Its dimensions are around $700 \times 300 \mathrm{~m}$, therefore an area of $210,000 \mathrm{~m}^{2}$. Using a conservative mining depth of $10 \mathrm{~m}$ and a mining yield of $60 \%$, the reserves would be about $1,260,000 \mathrm{~m}^{3}$. The yield proposed is based on the international experience and the model of a section of quarry 075 using 3D Block Expert (Fig. 20).

A theoretical annual production capacity of $42,000 \mathrm{~m}^{3}$ is calculated for a mining duration of 30 years in the quarry 079. Oscillations in the world market must be considered. It is also necessary to evaluate the considered area using economical geophysical methods to determine the distribution and magnitude of the waste material to be removed.

Regarding the cost of mining an optimization can be proposed using two different mining procedures. One procedure would be to use a greater surface area for mining at lower depth, and the second the construction of numerous mining levels to reach greater depths in a smaller area. The influence of volcanic rocks occurring at the rim of the deposit cannot be easily evaluated. It cannot be excluded that the deposit is affected by dikes, veins, or sills.

The small deposit of Violeta Imperial Syenite is a special case in regards to décor, where it shows smaller and narrow alkali feldspars that partially exhibit an interstitial fabric and a red-violet color. Its dimension is less than $10,000 \mathrm{~m}^{2}$. Considering a mining depth of $10 \mathrm{~m}$ and a rate of $60 \%$, the possible reserves of this deposit are calculated to be $60,000 \mathrm{~m}^{3}$. A production would be possible as a special target and would only be economically viable in combination with the main production of the pink-colored syenite.

Economic aspects of syenitoid deposits

The syenitoid group may also have a good position on the international market, since the range in décor for these 

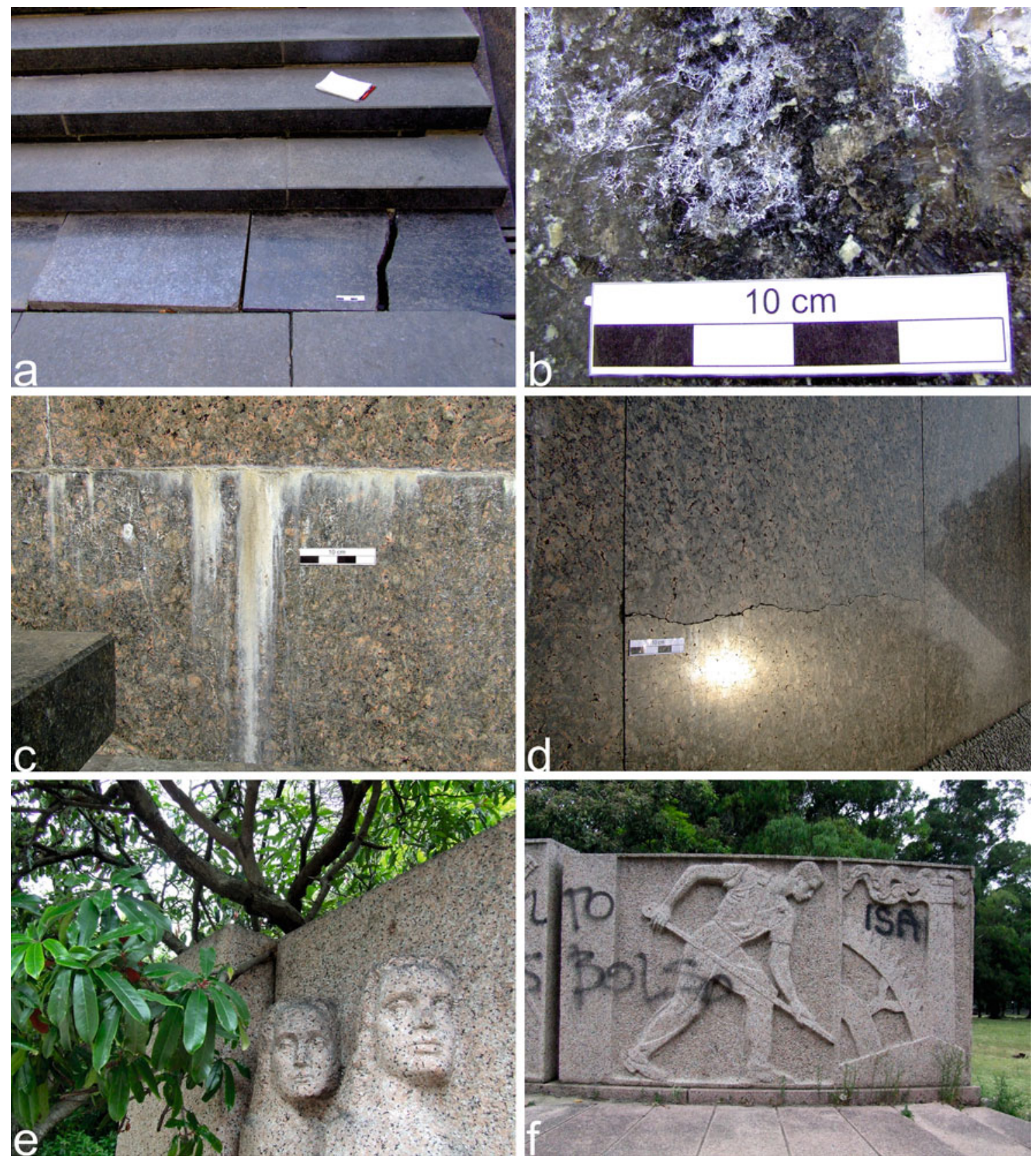

Fig. 22 Damages. a Moskart Granite broken floor cladding due to the low flexural strength of this rock; b Moskart Granite outdoor façade cladding with calcite precipitated in the microcracks, probably by the remobilization of the cement material; c Artigas Pearl Syenite outdoor cladding; precipitation of calcite from the cement in the joint between two slabs; d Artigas Pearl outdoor monument cladding with a crack

rocks is quite uncommon and very pleasing to the eye. As the petrophysical properties are not a limiting factor for their commercialization, these rocks could be sold at prices between 400 and $500 \mathrm{US} \$ / \mathrm{m}^{3}$ FOB. An annual production of $24,000 \mathrm{~m}^{3}$ is proposed for the Artigas Pearl Syenite. The attainable average market price of $500 \mathrm{US} \$ / \mathrm{m}^{3}$ would account for 12 million US\$ per year.

presumably posterior to the placement. Note the microcracks and little pores homogeneously distributed in the entire polished slab; e La Paz Granite urban monument affected by biomechanical deterioration due to the growth of a tree; and $\mathbf{f}$ the same monument shows anthropogenic deterioration (graffiti)

For the Pan de Azúcar Syenite an annual production of $3,500 \mathrm{~m}^{3}$ can be calculated. At market prices for white granitic stones of $200 \mathrm{US} \$ / \mathrm{m}^{3} \mathrm{FOB}$, the annual income of its mining would be 700,000 US\$.

Due to its color and décor the Salmon Red Syenite could be easily placed on the market in the category of red granitic dimensional stones. Its fabric makes it particularly 
interesting, because it gives the impression of being optically homogeneous. Taking an average price level of 500 US\$ per $\mathrm{m}^{3}$ and an average rate of $50 \%$ of exportable industrial blocks would result in an annual amount of 10.5 million US\$.

For the Violeta Imperial deposit the annual production of $2,000 \mathrm{~m}^{3}$ can be calculated. The prices for this kind of colored granitic stones average $450 \mathrm{US} \$ / \mathrm{m}^{3} \mathrm{FOB}$, allowing an annual value of 900,000 US\$.

\section{Final remarks and conclusions}

The Uruguayan commercial granites can be classified by their petrography and geochemistry into mafic rocks, granitoids, and syenitoids. For each of these groups a characterization has been carried out considering their color and décor, their petrophysical properties and the chance of their economically mining (deposit).

The only mafic rock deposits successfully mined in Uruguay today as dimensional stone are the dolerites. Even though there are two distinct geochemical and petrographical groups (A and $\mathrm{B}$, with high and low $\mathrm{TiO}_{2}$ contents, respectively), the décor and the petrophysical behavior is similar for both groups (samples U11O and U66). The exception to this assessment is the absence of the high quality black décor in Group B, since Absolute Black Dolerite (U11A) has only been found in the dikes of Group A (Morales Demarco et al. 2011). The high densities and especially the very low porosities and pore-related properties (e.g., water absorption, water vapor diffusion) of these rocks make them high quality granitic dimensional stones. They occupy a very favorable position in regards to their diverse applications; since they are very resistant to weathering and freezing and present no deterioration risks (See Table 7). The near-isotropic character of their petromechanical properties make possible their use as constructive elements subjected to high uniaxial applied loads, independently of the orientation of these elements (e.g., façades, support masts). Similarly, the thermal expansion is also near isotropic making possible the application of these rocks as elements that require an extreme low anisotropy (e.g., precision tables). Uruguayan dolerites, therefore, can be used as constructive elements in all indoor and outdoor applications and can occupy a relevant position on the international market.

The Uruguayan black commercial granites are comparable with several worldwide known dimensional stones in regards to décor and petrophysical properties (Table 6). The Absolute Black Dolerite can be compared with the Shanxi Black. They are similar in décor but the Uruguayan variety is slightly darker than Shanxi Black. In respect to their petrophysical properties they are very similar. Moderate Black Dolerite is comparable to the Impala Dark. The
Uruguayan dolerite has a finer grain size and higher compressive strength but a lower flexural strength.

The fine-grained gray granite varieties Cerro Áspero and Garzón Gray are similar in décor to the Padang Light Granite (G633/G3533) (China) and Kuro Gray (Finland). The petrophysical properties of the Uruguayan fine-grained gray granites are between those of these two internationally known granites (Table 7). Cerro Áspero Granite show higher UCS values as Padang Light, as well as slightly lower water absorption values. Oxidation of biotite under normal weathering conditions has an adverse effect on the color (by the staining of surrounding minerals) and in the rock stability. In the Cerro Áspero Granite no accumulation of iron hydroxide occurs due to the extremely low capillary water uptake. This characteristic places this granite in a better market position in comparison to the Padang Light, which is one of the most commercialized light gray and fine-grained granites. In its porosity and pore-related petrophysical properties, the Cerro Áspero Granite is comparable to the Kuro Gray Granite from Finland.

The Cerro Áspero Granite deposit can provide material for the dimensional stone industry as well as directly for the building sector. The large blocks can be cut with a gang saw blade for the production of polished slabs for wall cladding. The small- and medium-sized blocks provide material for flagstone and other products using normal saw blades or by simple handwork. For an increase of the competitiveness of the Cerro Áspero Granite it would be important to further analyze this commercial granite and compare it in detail with the world leading fine-grained gray granites. Also a promotion of this granite in international fairs and specialized literature would improve its position in the international market.

The color and décor of the Cufré Gray Blue Granite is not particularly interesting for the international market, but the rock can be commercialized at local and regional markets. Oxidation of the mafic enclaves and biotite clots with the development of orange-colored limonitic spots has been observed in the quarry. This phenomenon has not been seen in polished slabs used for outdoor façades (e.g., Torre de Antel; See Fig. 1a). The stone has a very high content of quartz (40\%), and thus a good durability as a polished surface. Due to the presence of a foliation, mafic enclaves, and biotite clots, the décor of this rock will vary within a block. The entire block needs to be cut to classify the finished product according to the décor (i.e., the presence or the absence of heterogeneities that will determine the products quality). Taking into consideration these facts and also the low porosity and low capillary water absorption, the Cufré Gray Blue can substitute for high quality imported stones for indoor and outdoor floor and façade cladding.

Maldonado Gray Granite is comparable in décor and petrophysical properties with the Italian Serizzo Antigorio 
gneiss. The Uruguayan granite shows higher strength values and lower water uptake. An optimization of the mining of this commercial granite could eventually lead to a higher production of larger blocks, which could place this granite on the international market.

Moskart or Soca Granite has similarities in décor (the greenish-gray color, the very coarse-grained texture, and the occasional iridescent feldspar) with the Flash Blue Granite from India and the Verde Butterfly from Brazil. The compressive strength is higher in the Uruguayan Granite and its flexural strength and water uptake values are in between both international granites. These characteristics make the Uruguayan granite a good competitor against the Indian and Brazilian granites. Due to its very coarse-grained texture and the presence of microcracks, the best method for mining this dimensional stone has proven to be the diamond wire saw. These characteristics, together with the relatively low values of its petrophysical properties, make a previous treatment of the slabs necessary to ensure their stability (e.g., chemical treatment to prevent water infiltration). Examples of this assessment are illustrated in Fig. 22a, where a step of a stone staircase broke due to the low flexural resistance of this stone. In Fig. 22b an outdoor façade cladding with precipitated calcite in the microcracks is shown, probably due to the remobilization of the cement material. Despite these application problems the Moskart Granite was commercialized on the international market during the last decade of the 20th century.

The décor of the Uruguayan colored syenitoids is so unique that there are no rocks to compare them with. The red granites, on the other hand, can be compared with numerous rocks. The equigranular facies of the $\mathrm{La} \mathrm{Paz}$ Granite can be compared to the Rosa Santa Eulalia, a granite from Portugal; the porphyritic facies with the Rosavel Granite from Spain and the Guazunambí Granite with the Marrom Gaucho Syenite from Brazil. Their petrophysical properties are comparable to those of the international granites, but the compressive strength is clearly higher than the Rosavel quartz syenite.

The appearance of numerous open pores in polished slabs of the Artigas Pearl Syenite, as well as in the deposit, is a factor to consider for its application. A coating will be necessary before its utilization as a working table or high quality flooring slabs. The use as a funerary monument is limited due to the high requirements in this sector. Basically, the application of this rock in the heavy duty sector has to be carefully considered, since it has relatively low petrophysical values in comparison to those of the syenitemonzonite groups of Mosch (2008).

The Salmon Red Syenite is in demand on the international market because of its color and décor, where it can be used in combination with rough surfaces and more dark red rocks for indoor and outdoor flooring slabs. Comparing the petrophysical values with the syenite-monzonite group investigated by Mosch (2008), this syenite has a very good position, allowing its use in sophisticated construction locations such as façades and countertops. Pore formation can be problematic in this dimensional stone, so that special attention has to be taken in the posterior industrial process (cutting and polishing). No negative aspects are known in regards to the weathering behavior.

The Pan de Azúcar White Syenite is comparable in décor to the Bianco Sardo from Italy. This rock could be interesting for the international market, as long as it can be extracted in industrially utilizable blocks. It could occupy a segment in the market, because the color "white" in hard rocks is not very common. In this sector, aplites and gneisses are offered, which very often show problems with posterior alteration accompanied by the formation of visible limonite.

Uruguayan syenitoids have been in use for several decades in the harbor facilities of Argentina and Uruguay. They have a high salinity resistance as well as a high resistance against applied loads (wash of the waves). This allows the application of small blocks on the international market for sectors that need high chemical resistant materials. With this special utilization, the deposits would be more competitive and have a better mining yield, since the high proportion of waste material is composed of small blocks. The waste material could be minimized by the production of aggregates parallel to the production of large blocks.

In summary, the color and décor, together with the petrophysical properties of the Uruguayan commercial granites places them in a very good position to compete with internationally known granitic stones. The dolerites are particularly interesting because they show excellent petrophysical properties that allow their use in all types of building applications. Their color and décor make the commercialization of these rocks independent of the changing fashion demands of the market.

Acknowledgments We would like to thank Dipl.-Ing. Peter Machner, Matthias Gehrke, and Dr. Alexander Wetzel for their help with the abrasion measurements at the AMPA Laboratory (Amtliche Materialprüfanstalt für das Bauwesen) of the University of Kassel. Further thanks go to Dr. Rudolf Naumann for the geochemical measurements at the GFZ (GeoForschungsZentrum) in Potsdam; and Janoušek V, Farrow CM, Erban V, and Šmíd J for the use of the program GCDKit (GeoChemical Data ToolKIT) for plotting the geochemical data. In Uruguay our thanks go to Ing. Jorge Spoturno, Ing. Haroldo Albanell, Dipl. Geol. Silvana Martinez, Dr. Jorge Bossi, Dr. Leda Sánchez Bettucci, and MsC. Juan Ledesma for their comments, suggestions, and support. We also would like to thank the companies Black Stone S.A., Comercio Exterior S.A., Pimafox S.A., Vodelín S.A., and Rufo Hnos S.A. Special thanks also go to the students, friends, and family in Uruguay and Germany for their help and support. We are very grateful to Dr. Klaus Wemmer not only for the help in the field, but also for his support in scientific and 
existential matters. We also thank Christian Gross for his help with the English corrections. M. Morales Demarco is grateful to the DAAD for the long-term fellowship (A/07/98548).

Open Access This article is distributed under the terms of the Creative Commons Attribution License which permits any use, distribution, and reproduction in any medium, provided the original author(s) and the source are credited.

\section{Appendix}

See Appendix Tables 8, 9, 10 and 11.

Table 8 Petrophysical properties: density, porosity, water absorption (W.A.)

\begin{tabular}{|c|c|c|c|c|c|c|c|c|c|c|}
\hline Rock/test & ID & $\begin{array}{l}\text { Bulk } \\
\text { density } \\
\left(\mathrm{g} / \mathrm{cm}^{3}\right)\end{array}$ & $\begin{array}{l}\text { Matrix } \\
\text { density } \\
\left(\mathrm{g} / \mathrm{cm}^{3}\right)\end{array}$ & $\begin{array}{l}\text { Porosity } \\
(\%)\end{array}$ & $\begin{array}{l}\text { Average } \\
\text { pore radii } \\
(\mu \mathrm{m})\end{array}$ & $\begin{array}{l}\text { Most abundant } \\
\text { pore radii }(\mu \mathrm{m})\end{array}$ & $\begin{array}{l}\text { Capillary } \\
\text { W.A. } \\
\left(\mathrm{kg} / \mathrm{m}^{2} \mathrm{~h}^{0.5}\right)\end{array}$ & $\begin{array}{l}\text { Forced } \\
\text { W.A. } \\
\text { (wt\%) }\end{array}$ & $\begin{array}{l}\text { Unforced } \\
\text { W.A. } \\
\text { (wt\%) }\end{array}$ & $S$ value \\
\hline Absolute Black Dolerite & U11A & 2.99 & 2.99 & 0.03 & 0.097 & 0.013 & 0.04 & 0.01 & 0.01 & 0.96 \\
\hline Moderate Black Dolerite & U11O & 3.02 & 3.02 & 0.06 & 0.064 & 0.021 & 0.09 & 0.02 & 0.02 & 0.97 \\
\hline Oriental (Pimafox) Dolerite & U66 & 2.97 & 2.98 & 0.12 & 0.209 & 0.084 & 0.13 & 0.04 & 0.03 & 0.87 \\
\hline Arapey Black Basalt & U49 & 2.94 & 2.96 & 0.98 & 0.032 & 0.021 & 0.16 & 0.33 & 0.28 & 0.86 \\
\hline Maldonado Gray Granite & $\mathrm{U} 2$ & 2.64 & 2.64 & 0.48 & 0.051 & 0.053 & 0.10 & 0.18 & 0.17 & 0.91 \\
\hline Chamangá Gray Granite & U4 & 2.69 & 2.69 & 0.27 & 0.077 & 0.021 & 0.10 & 0.10 & 0.07 & 0.70 \\
\hline Cuchilla del Perdido Granite & U53 & 2.72 & 2.73 & 0.31 & 0.070 & 0.084 & 0.11 & 0.12 & 0.09 & 0.80 \\
\hline Cerro Áspero Gray Granite & U70 & 2.65 & 2.67 & 0.80 & 0.090 & 0.133 & 0.11 & 0.30 & 0.27 & 0.89 \\
\hline Moskart Granite & $\mathrm{U} 7$ & 2.66 & 2.67 & 0.58 & 0.070 & 0.008 & 0.07 & 0.22 & 0.19 & 0.89 \\
\hline Salmon Red Syenite & U15 & 2.61 & 2.64 & 0.86 & 0.042 & 0.084 & 0.82 & 0.33 & 0.30 & 0.91 \\
\hline Artigas Peart Syenite & U46 & 2.64 & 2.68 & 1.15 & 0.077 & 0.008 & 0.19 & 0.44 & 0.40 & 0.93 \\
\hline Vioieta Imperial Syenite & U47 & 2.62 & 2.66 & 1.34 & 0.057 & 0.335 & 0.22 & 0.51 & 0.43 & 0.83 \\
\hline
\end{tabular}

Table 9 Petrophysical properties: thermal expansion, water vapor diffusion, and ultrasound

\begin{tabular}{|c|c|c|c|c|c|c|c|c|c|c|c|c|}
\hline \multirow[t]{2}{*}{ Rock/test direction } & \multirow[t]{2}{*}{ ID } & \multicolumn{5}{|c|}{ Thermal expansion $\left(10^{-6} \mathrm{~K}^{-1}\right)$} & \multicolumn{3}{|c|}{ Water vapor diffusion } & \multicolumn{3}{|c|}{ Ultrasound $(\mathrm{km} / \mathrm{s})$} \\
\hline & & $x$ & $y$ & $z$ & $\begin{array}{l}\text { Average } \\
\text { value }\end{array}$ & $\begin{array}{l}\text { Anisotropy } \\
(\%)\end{array}$ & $x$ & $y$ & $z$ & $x$ & $y$ & $z$ \\
\hline Absolute Black Dolerite & U11A & 6.66 & 6.79 & 6.68 & 6.71 & 2 & 8,487 & 6,069 & 5,583 & 5.84 & 5.72 & 5.92 \\
\hline Moderate Black Dolerite & $\mathrm{U} 11 \mathrm{O}$ & 6.53 & 6.55 & 6.87 & 6.65 & 5 & 5,344 & 5,473 & 5,599 & 6.41 & 6.49 & 6.34 \\
\hline Oriental (Pimafox) Dolerite & U66 & 5.67 & 5.87 & 5.80 & 5.78 & 2 & 120 & 809 & 1,130 & 5.84 & 5.58 & 5.61 \\
\hline Arapey Black Basalt & U49 & 6.21 & 6.03 & 5.75 & 6.00 & 7 & -355 & -781 & $-1,251$ & 5.73 & 5.88 & 5.41 \\
\hline Maldonado Gray Granite & $\mathrm{U} 2$ & 7.3 & 7.76 & 8.04 & 7.70 & 9 & 83 & 228 & 269 & 5.15 & 5.73 & 5.31 \\
\hline Chamangá Gray Granite & $\mathrm{U} 4$ & 8.35 & 7.93 & 7.30 & 7.86 & 13 & 1,232 & 851 & 1,099 & 5.73 & 5.22 & 5.40 \\
\hline Cuchilla del Perdido Granite & U53 & 7.39 & 7.88 & 8.28 & 7.85 & 11 & 528 & 456 & 459 & 5.85 & 5.62 & 5.57 \\
\hline Cerro Áspero Gray Granite & $\mathrm{U} 70$ & 6.94 & 6.74 & 6.50 & 6.73 & 6 & N.d. & N.d. & N.d. & 4.27 & 4.08 & 3.38 \\
\hline Moskart Granite & $\mathrm{U} 7$ & 7.78 & 9.47 & 8.46 & 8.57 & 18 & 374 & 526 & 358 & 5.83 & 5.57 & 5.46 \\
\hline Salmon Red Syenite & U15 & 6.27 & 6.34 & 6.96 & 6.52 & 10 & 1,508 & 1,182 & 1,046 & 5.15 & 5.18 & 5.03 \\
\hline Artigas Pearl Syenite & U46 & 5.74 & 6.79 & 6.18 & 6.23 & 15 & 442 & 1,017 & 588 & 5.08 & 5.03 & 4.88 \\
\hline Violeta Imperial Syenite & U47 & 6.45 & 6.45 & 7.16 & 6.69 & 10 & 861 & 525 & 797 & 5.59 & 5.45 & 5.27 \\
\hline
\end{tabular}




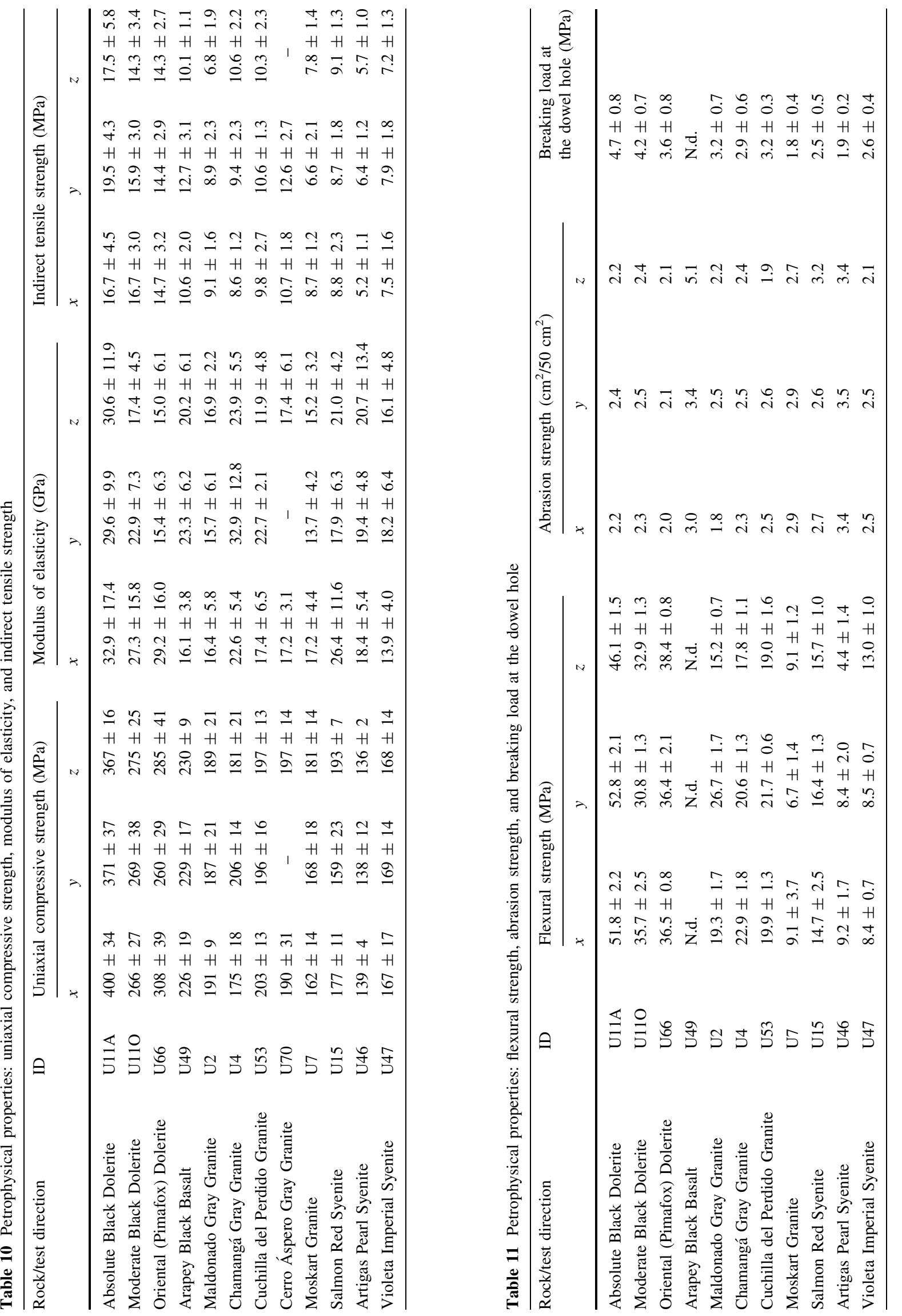




\section{References}

Allaby A, Allaby M (1990) The concise Oxford dictionary of earth sciences. Oxford University Press, Oxford

Almeida FFM, Amaral G, Cordani UG, Kawashita K (1973) The precambrian evolution of the South American cratonic margin, south of Amazonas river. In: Nairn ACM, Kanes WH, Stehli FG (eds) The ocean basins and margins. Plenum, New York, pp 411-446

Artur AC, Meyer AP, Wernick E (2001) Caracterísiticas tecnológicas de granitos ornamentais: a influência da mineralogia, textura e estrutura da rocha. Dados Comparativos e implicações de utilização. In I Simpósio Brasileiro De Rochas Ornamentais E II Seminário De Rochas Ornamentais Do Nordeste, Salvador

ASTM C119-11 (2011) Standard terminology relating to dimension stone. doi:10.1520/C0119-11

Best MG (2003) Igneous and metamorphic petrology. Blackwell Publishing, Turin, p 729

Boone GM (1969) Origin of clouded red feldspars petrologic contrasts in a granitic porphyry intrusion. Am J Sci 267:633-668

Börner K, Hill D (2010) Große Enzyklopädie der Steine: Die Naturstein-Datenbank. CD-ROM. Abraxas Verlag GmbH

Bossi J, Campal N (1991) Granitos negros filonianos del UruguayResultados de las Investigaciones. Ed Facultad de Agronomía, Montevideo

Bossi J, Ferrando L (2001) Carta Geológica del Uruguay a escala 1/500 000, v. 2.0, versión digital. Ed. Cátedra de Geología, Facultad de Agronomía, Montevideo

Bossi J, Navarro R (2000) Recursos Minerales del Uruguay; versión digital, Ed. Rojobona, Montevideo, pp 418

Bossi J, Navarro R (2001) Recursos Minerales del Uruguay; versión digital, Ed. Rojobona, Montevideo, pp 418. ISBN 9974-39-281-0

Bossi J, Schipilov A (2007) Rocas ígneas básicas del Uruguay. Facultad de Agronomía, Montevideo, p 364

Bossi J, Fernández A, Elizalde G (1965) Predevoniano en el Uruguay. Boletín Facultad de Agronomía 78:1-49 Montevideo-Uruguay

Büdel J (1957) Die "Doppelten Einebnungsflächen" in den feuchten Tropen. Zeitschrift für Geomorphologie NF 1:201-228

Caruso LG (1987) Rocas de Aplicación, Proyecto URU/86-002 Reactivación de la Economía y Promoción de Inversiones

Castro de Lima JJ, Paraguassú AB (2004) Linear thermal expansion in granitic rocks: influence of apparent porosity, grain size and quartz content. Bull Eng Geol Environ 63:215-220

Centre for Development of Stones-Jaipur (2011). http://www.cdosindia.com/CDOS/Production.html

Coronel N, Risso A, Cestau L, Spoturno J, Gómez C, Heizen W, Mati C, Roth W, Theune C, Stampe W (1987) Memoria de la carta de materias primas minerales no metálicas-a escala 1/1.000.000. DI.NA.MI.GE

Comunità Economica Europea-Uruguay. Piedras Ornamentales del Uruguay. La Cartotecnica, Rovereto

De La Roche H, Leterrier J, Grandclaude P, Marchal M (1980) A classification of volcanic and plutonic rocks using R1R2diagram and major element analyses-its relationships with current nomenclature. Chem Geol 29:183-210

DIN 52108 (1988) Prüfung anorganischer nichtmetallischer Werkstoffe; Verschleißprüfung mit der Schleifscheibe nach Böhme. Beuth Verlag, Berlin

DIN EN 12372 (1999) Prüfverfahren für Naturstein-Bestimmung der Biegefestigkeit unter Mittellinienlast. Beuth Verlag, Berlin

DIN EN 12407 (2007) Prüfverfahren für Naturstein—Petrographische Prüfung. Beuth Verlag, Berlin

DIN EN 12670 (2000) Naturstein-Terminologie. Beuth Verlag, Berlin
DIN EN 12670 (2001) Naturstein-Kriterien für die Bezeichnung. Beuth Verlag, Berlin

DIN EN 13364 (2002) Prüfung von Naturstein-Bestimmung der Ausbruchlast am Ankerdornloch. Beuth Verlag, Berlin

DIN EN 13755 (2008) Prüfverfahren für Naturstein-Bestimmung der Wasseraufnahme bei atmosphärischem Druck. Beuth Verlag, Berlin

DI.NA.MI.GE. (Dirección Nacional de Minería y Geología)C.E.R.A.M. (Centro de Estadísticas y Recaudación de la Actividad Minera) (2007) Estadísticas de producción parcial 2007

DI.NA.MI.GE. (Dirección Nacional de Minería y Geología)C.E.R.A.M. (Centro de Estadísticas y Recaudación de la Actividad Minera) (2008) Estadísticas de producción parcial 2007

DI.NA.MI.GE. (Dirección Nacional de Minería y Geología) (2011). www.dinamige.gub.uy

Direcção Geral de Energia e Geologia (DGEG), Divisão de Estatística (2011). http://www.dgge.pt/

Federación Española de la Piedra Natural (2008) Informe anual Sector de la Piedra Natural 2007. http://www.fdp.es/wp-content/ uploads/2010/12/Informe-sector-2007.pdf

Ferrando L, Fernández A (1971) Esquema tectónico-cronoestatigráfico del predevoniano en Uruguay. In: XXV Congreso Brasilero de Geología, vol 1. San Pablo, Paulo, pp 199-210

Fragoso César R (1980) O cratón do Río de la Plata e o Cinturão Dom Feliciano no Escudo Uruguaio-Sul-Riograndense. XXXI Congresso Brasileiro de Geología; Anais, 5:1879-2892. Brasil

Gómez-Heras M, Smith BJ, Fort R (2006) Surface temperature differences between minerals in crystalline rocks: implications for granular disaggregation of granites through thermal fatigue. Geomorphology 78:236-249

Heldal T, Kjølle I, Meyer GB, Dahlgren S (2008) National treasure of global significance. Dimension-stone deposits in larvikite, Oslo igneous province, Norway. In: Slagstad T (ed) Geology for society, vol 11. Geological Survey of Norway Special Publication, Trondheim, pp 5-18

Hirschwald J (1912) Die Prüfung der natürlichen Bausteine auf ihre Verwitterungsbeständigkeit. Verlag W Ernst \& Sohn, Berlin

Hoffmann A (2006) Naturwerksteine Thailands: Lagerstättenerkundung und Bewertung. Dissertation, University of Göttingen

Hoffmann A, Siegesmund S (2007) The dimension stone potential of Thailand-overview and granite site investigations. In: Přikryl $\mathrm{R}$, Smith BJ (eds) Building stone decay: from diagnosis to conservation, vol 271. Geological Society of London Special Publications, London, pp 43-54

Illiev IG (1967) An attempt to estimate the degree of weathering of intrusive rocks from their physica-mechanical properties. In: Proceedings of the 1st Congress International Society for Rock Mechanics, Lisbon, vol 1, pp 109-114

Jackson JA (1997) Glossary of geology, 4th edn. American Geophysical Institute, Alexandria

Jorge Quiroz C Consultores Asociados (2006) Estudio de Mercado y Competitividad de las Industrias de Rocas Ornamentales, Informe Final. http://www.jcih.cl/documentacion/estudios/ Estudios\%20de\%20Mercado\%20y\%20Competitividad\%20Rocas $\% 20$ Ornamentales.pdf

Kelter D, Langer AK \& Walter L (1999) Anwendung der UN Rahmen-Vorratsklassifikation auf Industrieminerale, Steine und Erden. Slaby, D. \& Brenzinski, H. (ed) In: Rohstoffwirtschaft im Prozess der Transformation: D 205 Wirtschaftswissenschaften. Technische Universität Berg-akademie Freiberg, Freiberg, pp 189-206

Koch A (2005) Deformation von Fassadenplatten aus Marmor: Schadenskartierungen und gesteinstechnische Untersuchungen 
zur Verwitterungsdynamik von Marmorfassaden. Dissertation, University of Göttingen

Koch A, Siegesmund S (2004) The combined effect of moisture and temperature on the anomalous behavior of marbles. Environ Geol 46(3-4):350-363

Köhler W (1991) Untersuchungen zu Verwitterungsvorgängen an Carrara-Marmor in Potsdam-Sanssouci. Berichte zu Forschung und Praxis der Denkmalpflege in Deutschland. SteinschädenSteinkonservierung 2:50-53

Kretz R (1983) Symbols for rock-forming minerals. Am Mineral 68:277-279

Le Maitre RW, Streckeisen A, Zanettin B, Le Bas MJ, Bonin B, Bateman P, Bellieni G, Dudek A, Efremova S, Keller J, Lameyre J, Sabine PA, Schmid R, Sørensen H, Woolley AR (2002) Igneous rocks a classification and glossary of terms. Recommendations of the international union of geological sciences subcommission on the systematics of igneous rocks. Cambridge University Press, Cambridge

Middlemost E (1997) Magmas, rocks and planetary development. A survey of magma/igneous rock systems. Geol Mag 135:143-158

Monicard RP (1980) Properties of reservoir rocks: core analysis. Edition Technip, Paris

Montani C (2008) Stone 2008 Repertorio economico mondiale World marketing handbook Faenza Editrice. ISBN 978-88-8138-121

Morales Demarco M, Jahns E, Rüdrich J, Oyhantçabal P, Siegesmund $S$ (2007) The impact of partial water saturation on rock strength: an experimental study on sandstone. $\mathrm{Z}$ dt Ges Geowiss 158:869-882

Morales Demarco M, Oyhantçabal P, Stein KJ, Siegesmund S (2011) Black dimensional stones: geology, technical properties and deposit characterization of the dolerites from Uruguay. Environ Earth Sci 63:7-8, 1879-1909. doi:10.1007/s12665-010-0827-5. Special issue: monuments under threat: environmental impact, preservation strategies and natural stone resources

Morales Pérez E (2004) Rocas Ornamentales del Uruguay. Trabajo Final del Curso "Recursos Minerales". Universidad de la República, Montevideo

Morales Pérez E, Muzio R (2005) Balanço mineral dos granitos ornamentais do Uruguai periodo 1990-2003. I International Congress on Dimensional Stones and II Simpósio Brasileiro de Rochas Ornamentais, Guarapari, Brazil

Mosch S (2009) Optimierung der Exploration, Gewinnung und Materialcharakterisierung von Naturwerksteinen. Dissertation, University of Göttingen. http://webdoc.sub.gwdg.de/diss/2009/ $\operatorname{mosch} /$

Mosch S, Siegesmund S (2007) Statistische Bewertung gesteintechnischer Kenndaten von Natursteinen. Z dt Ges Geowiss 158(4): 821-868

Mosch S, López de Luchi MG, Siegesmund S (2007) Dimensional stones in Argentina. Z dt Ges Geowiss 158(3):447-469

Mosch S, Nikolayew D, Ewiak O, Siegesmund S (2010) Optimized extraction of dimension stone blocks. Environ Earth Sci 63:7-8, 1911-1924. doi:10.1007/s12665-010-0825-7. Special issue: monuments under threat: environmental impact, preservation strategies and natural stone resources

Muzio R, Artur AC (1999) Petrological features of the Santa Teresa Granitic Complex Southeastern Uruguay. J S Am Earth Sci 12(5):501-510

Nakano S, Akai J, Sugaki A (2002) Fluorite particles inducing butterfly aggregates of incipient microperthite in alkali feldspar from a syenite, the Patagonian Andes, southern Chile. Am Miner 87:1377-1383

Nikolayew D, Siegesmund S, Mosch S, Hoffmann A (2007) Modelbased prediction of unfractured rock masses. Zeitschrift der Deutschen Gesellschaft für Geowissenschaften 158(3):483-490
Oyhantçabal P (2005) The Sierra Ballena Shear zone: kinematics, timing and its significance for the geotectonic evolution of southeast Uruguay. Dissertation, University of Göttingen. http://webdoc.sub.gwdg.de/diss/2005/oyhantcabal_cironi/

Oyhantçabal P, Derregibus MT, Muzio R (1990a) Contribución al conocimiento petrográfico, geoquímico y estructural del Granito de La Paz. Resúmenes Ampliados 1:81-89 Congreso Uruguayo de Geología, Montevideo

Oyhantçabal P, Medina E, Spoturno J (1990b) Geología y petrología del stock de gabro del Arroyo Mahoma. Resúmenes Ampliados 1:115-121 Congreso Uruguayo de Geología, Montevideo

Oyhantçabal P, Muzio R, Derregibus MT, Nardi LVS (1998) The Soca intrusion: a rapakivi granite of Uruguay. J S Am Earth Sci 11(2):169-178

Oyhantçabal P, Siegesmund S, Stein KJ, Spoturno J (2007) Dimensional stones in Uruguay: situation and perspectives. Z Ges Geowiss 158(3):417-428

Oyhantçabal P, Siegesmund S, Wemmer K, Presnyakov S, Layer P (2009) Geochronological constraints on the evolution of the southern Dom Feliciano Belt (Uruguay). J Geol Soc Lond 166:1075-1084. doi:10.1144/0016-76492008-122

Oyhantçabal P, Siegesmund S, Wemmer K (2010) The Río de la Plata Craton: a review of units, boundaries, ages and isotopic signature. Int J Earth Sci 100(2-3):201-220. doi:10.1007/ s00531-010-0580-8

Palmstrøm A (1982) The volumetric joint count-a useful and simple measure of the degree of rock jointing-Abstracts, Proceedings of the 4th International Congress of International Association of Engineering Geology, New Delhi 5:S.221-S.228

Palmstrøm A (1996) The weighted joint density method leads to improved characterization of jointing. Conference on recent advances in tunnelling technology, New Delhi

Palmstrøm A (2001) Measurement and characterization of rock mass jointing. In: Sharma VM, Saxena KR (eds) In situ characterization of rocks. A.A Balkema Publishers, Lise/Abingdon/Exton/ Tokyo

Peschel A (1977) Natursteine VEB Deutscher Verlag für Grundstoffindustrie, Leipzig

Plümper O, Putnis A (2009) The complex hydrothermal history of granitic rocks: multiple feldspar replacement reactions under subsolidus conditions. J Petrology 50(5):967-987

Preciozzi F (1993) Petrography and geochemistry of five granitic plutons from South-Central Uruguay: contribution to the knowledge of the Piedra Alta Terrane. Ph.D. Thesis, Universite du Quebec à Montreal, Quebec, p 200

Preciozzi F, Spoturno J, Heinzen W, Rossi P (1985) Memoria explicativa de la carta geológica del Uruguay a la escala 1:500.000. DI.NA.MI.GE

Putnis A, Hinrichs R, Putnis CV, Golla-Schindler U, Collins LG (2007) Hematite in porous red-clouded feldspars: evidence of large-scale crustal fluid-rock interaction. Lithos 95:10-18

Quick GW (2002) Selective guide to the specification of dimension stone. Discov Stone 1(1):8-21. (http://www.discoveringstone. com)

Rohowski H (2001) Druckfestigkeit und Ausbruchlast neu geregelt. Naturstein 3:88-92

Rüdrich J (2003) Gefügekontrollierte Verwitterung natürlicher und konservierter Marmore. Dissertation, University of Göttingen

Sánchez Bettucci L, Peel E, y Oyhantçabal P (2010) Precambrian geotectonic units of the Río de La Plata craton. International Geology Review 52:32-50

Scheer K (1964) Estudio sobre la Industria del Granito y del Mármol en el Uruguay. BGP Bergbau-Planung GmbH, Essen

Siegesmund S, Dahms M (1994) Fabric-controlled anisotropy of elastic, magnetic and thermal properties. In: Bunge HJ, 
Siegesmund S, Skrotzki W, Weber K (eds) Textures of geological materials. DGM Informationsgesellschaft, Oberursel

Siegesmund S, Dürrast H (2011) Physical and mechanical properties of rocks. In: Siegesmund S, Snethlage R (eds) Stone in architecture: properties, durability, 4th edn. Springer, Berlin, p 552

Siegesmund S, Nikolayev D, Hoffmann A, Mosch S (2007a) 3Dblock-expert. Naturstein 5:102-107

Siegesmund S, Nikolayev D, Mosch S, Hoffmann A (2007b) Modellbased prediction of unfractured rock masses. Z dt Ges Geowiss 158(3):483-490, Stuttgart

Siegesmund S, Mosch S, Scheffzük Ch, Nikolayev DI (2008) The bowing potential of granitic rocks: rock fabrics, thermal properties and residual strain. Environ Geol 55:1437-1448

Singewald C (1992) Naturstein-Exploration und Gewinnung. 260 S., Köln, Bad Bentheim (Rudolf Müller)

Sousa LMO (2010) Evaluation of joints in granitic outcrops for dimension stone exploitation. Q J Eng Geol Hydrogeol 43:85-94. doi:10.1144/1470-9236/08-076

Spoturno J, Oyhantçabal P, Aubet N, Cazaux S (2004a) Mapa geológico y de recursos minerals del departamento de San José a escala 1/100.000, Memoria Explicativa, Capítulo II Geología. Proyecto CONICYT 6019

Spoturno J, Oyhantçabal P, Aubet N, Cazaux S (2004b) Mapa geológico y de recursos minerals del departamento de Canelones a escala 1/100.000, Memoria Explicativa, Capítulo II Geología. Proyecto CONICYT 6019

Spoturno J, Oyhantçabal P, Aubet N, Cazaux S (2004c) Mapa geológico y de recursos minerals del departamento de Montevideo a escala 1/100.000, Memoria Explicativa, Capítulo II Geología. Proyecto CONICYT 6019

Steiger M, Charola AE, Sterflinger K (2011) Weathering and deterioration. In: Siegesmund S, Snethlage R (eds) Stone in architecture: properties, durability, 4 th edn. Springer, Dordrecht, p 552

Stein KJ (2007) Vorkommen an Naturwerksteinen in Benin und deren Klassifikation nach dem UNFCR. Deposits of dimension stone in
Benin and their classification after UNFCR. Z dt Ges Geowiss 158:429-446, Stuttgart

Streckeisen A (1976) To each plutonic rock its proper name. Earth Sci Rev 12:1-33

Strohmeyer D (2003) Gefügeabhängigkeit technischer Gesteinseigenschaften. Dissertation, University of Göttingen

Taylor HP (1977) Water/rock interactions and the origin of $\mathrm{H}_{2} \mathrm{O}$ in granitic batholiths. J Geol Soc Lond 133:509-558

Techera J, Arriguetti R, Spoturno J (2004a) Mapa geológico y de recursos minerals del departamento de San José a escala 1/100.000, Memoria Explicativa, Parte III Recursos minerales. Proyecto CONICYT 6019

Techera J, Arriguetti R, Spoturno J (2004b) Mapa geológico y de recursos minerals del departamento de Canelones a escala 1/100.000, Memoria Explicativa, Parte III Recursos minerales. Proyecto CONICYT 6019

Techera J, Arriguetti R, Spoturno J (2004c) Mapa geológico y de recursos minerals del departamento de Montevideo a escala 1/100.000, Memoria Explicativa, Parte III Recursos minerales. Proyecto CONICYT 6019

Twidale CR (2002) The two-stage concept of landform and landscape development involving etching: origin, development and implications of an idea. Earth Sci Rev 57:37-74

United Nations (2010) Framework classification for fossil energy and mineral reserves and resources 2009. Economic Commission for Europe, Committee on Sustainable Energy

Vázquez P, Siegesmund S, Alonso FJ (2011) Bowing of dimensional granitic stones. Environ Earth Sci 63:1603-1612

Weiss G (1992) Die Eis- und Salzkristallisation im Porenraum von Sandsteinen und ihre Auswirkungen auf das Gefüge unter besonderer Berücksichtigung gesteinsspezifischer Parameter. Münchner Geowiss Abh B 9, Verlag Dr. Friedrich Pfeil, Munich

Weiss T, Siegesmund S, Kirchner D, Sippel J (2004) Insolation weathering and hygric dilatation as a control on building stone degradation. Environ Geol 46(3-4):402-413 